4 norden 


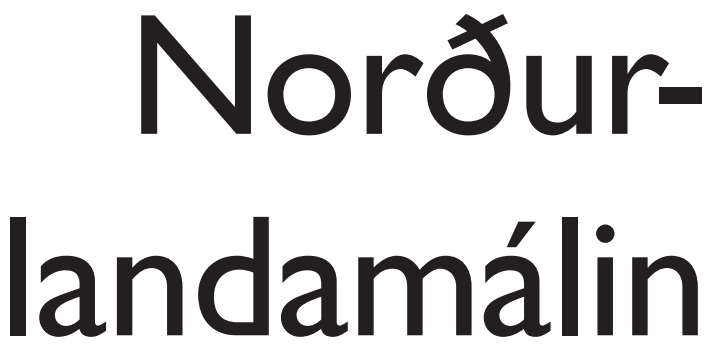

međ rótum og fótum

Ritstjóri Iben Stampe Sletten 


\section{Norðurlandamálin með rótum og fótum}

Nord 2004:11

(C) Norræna ráðherranefndin, Kaupmannahöfn 2004

ISBN 92-893-1040-5

Ritstjóri: Iben Stampe Sletten

Grafiskur verkefnisstjóri: Kjell Olsson

Umbrot: Carl-H.K. Zakrisson, www.polytype.dk

Myndskýring: Ivar Gjørup, www.egoland.dk

Kort: John Fowlie/studio16a

Prentun: Akaprint A/ S, Århus 2005

Fjöldi eintaka: 1000

Prentað á umhverfisvænan pappír sem uppfyllir

norrænar kröfur um umhverfismerkingar.

Printed in Denmark

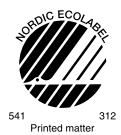

Norræna ráoherranefndin

Store Strandstræde 18

DK-1255 Kaupmannahöfn K

Sími (+45) 33960200

Bréfasími (+45) 33960202

www.norden.org

\section{Norðurlandaráð}

Store Strandstræde 18

DK-1255 Kaupmannahöfn K

Sími (+45) 33960400

Bréfasími (+45) 33111870

\section{Norræna ráðherranefndin}

var stofnuð árið 1971 sem samstarfsvettvangur ríkisstjórna Norðurlanda. Ráðherranefndin leggur fram tillögur á pingum Norðurlandaráðs, vinnur úr sampykktum ráđsins, gerir Norðurlandaráði grein fyrir niðurstöðum samstarfsins og stjórnar starfinu á hinum ólíku sviðum. Umsjón með samræmingu samstarfsins hafa samstarfsráðherrar sem valdir eru af ríkisstjórnum viðkomandi landa. Samsetning ráðherranefndarinnar er mismunandi og ræðst af pví hvaða málefni er til meðhöndlunar.

\section{Norðurlandaráð}

var stofnað árið 1952 sem samstarfsvettvangur pjóðpinga og ríkisstjórna Danmerkur, Íslands, Noregs og Svípjóðar. premur árum síðar bættist Finnland í hópinn. Fulltrúar Færeyja og Grænlands eru hluti landsdeildar Danmerkur og fulltrúar Álands eru hluti peirrar finnsku. Í Norðurlandaráði eiga sæti 87 fulltrúar. Norðurlandaráð tekur frumkvæði, veitir ráðgjöf og hefur með höndum eftirlit með norrænu samstarfi. Starfsemi Norðurlandaráðs fer fram á Norðurlandaráðspingum, í forsætisnefnd Norðurlandaráðs og í fastanefndum pess.

\section{Norræna tungumálasamstarfið}

Ein af forsendum samstarfs Norðurlandanna, pjóðlegs, menningar-, efnahags- og stjórnmálalegs, er skyldleiki tungumálanna. Á vegum Norrænu ráðherranefndarinnar starfar sérstakur stýrihópur við samhæfingu og stjórn tungumálasamstarfs Norðurlanda. Meginhlutverk hans er eftirfarandi: 1) að veita Norrænu ráðherranefndinni og Norðurlandaráði ráðgjöf er varðar málefni og stefnu norrænna tungumála, 2) að vera samstarfsvettvangur norrænna málnefnda og sendikenn- ara, 3) að hafa yfirumsjón með pverfaglegu styrktaráætluninni, Nordplus - tungumál og bera ábyrgð á framkvæmd hennar. Stýrihópur um tungumálasamstarf Norrænu ráðherranefndarinnar vinnur að eftirfarandi markmiðum: Að efla innbyrðis skilning norrænna tungumála, að auka pekkingu á tungumálum Norðurlandanna, að stuðla að lýðræðislegri stefnumótun og viðhorfum til tungumála á Norðurlöndum og að styrkja stöðu Norðurlandamála á Norðurlöndum og utan peirra. 


\section{Efni}

\section{Formáli 9}

Netútgáfa á „Norðurlandamálin međ rótum og fótum“ I

Iben Stampe Sletten 11

Yfirlit yfir uppbyggingu netefnisins 12

Kynning á greinum 13

Norræn málsaga 13

Rætur nútímans í fortíðinni 13

Fjölbreytileiki Norðurlanda 14

Pað læra börnin sem fyrir peim er haft - mállýskur nútímans 15

Enskan - ógn eða auðlind? 16

Mál eru breytingum undirorpin - en hvert stefna pau? 17

Norræn tungumál ađ̃ fornu og nýju / Arne Torp 19

Norðurlandamálin: Prjár ættir - mörg mál 23

Indóevrópska málaættin 27

Ættartréð og norræn mál 30

Germanska málaættin 31

Germanska hljóðłærslan 32

Erfðaorð, tökuorð og aðkomuorð 33

Skandinavía: Mismunandi mál eđa bara mállýskur? 35

Fjarlægðarmál 36

Staðalmál 40

Mállýskusamfella og stađalmál innan germanska málsvæđisins 41

Prjú eđa fimm mál? 43

Hvers vegna bókmál og nýnorska? 44

Norræn nútímamál 44 
Ættartréð endurtekið 46

bykkt I 49

Mjúkir samhljóðar 49

Skroll $r \quad 49$

Söguleg skipting norrænna mála með bylgjukenningunni 52

Frá frumnorrænu fram á vikingaöld 52

Rúnir 52

Austurnorræna og vesturnorræna 54

Á hámiðöldum: Norðurnorræna og suðurnorræna 56

Nýir tímar: Eyjanorræna og skandinavíska 59

Hvers vegna eru skandinavíska og eyjanorræna fjarlægðarmálýskur? 60

Mismunandi beyging 60

Mismunandi framburður 65

Orðin ráđa mestu um skilninginn 66

Er ættartréð úr sér gengið? 68

Skilningur milli skandinavískra grannmála - aðalatriði norrænnar samkenndar 70

Er skilningur á grannmálum í hættu? 73

Ritaskrá 74

Vefslóđir 74

Finnska / Kaisa Häkkinen 75

Finnska og skyld mál 75

Forsaga Finna 76

Finnskar mállýskur 76

Tímabil í sögu finnsku 79

Fornfinnska og miðaldafinnska 79

Gamla ritfinnskan 80

Eldri nútímafinnska 80

Nútímafinnska 81 
Hljóðkerfi nútímafinnsku 82

Formkerfisleg grundvallareinkenni 84

Aðalatriði setningafræðinnar 90

Orðaforði 91

Finnskan í dag og á morgun 94

Ritaskrá 95

Vefslóðir 95

Samísk mál / Mikael Svonni 97

Samískar byggðir og samísk mál 97

Söguleg samskipti 98

Tímabilið frá árinu 4000 til 2000 fyrir Krist 99

Tímabilið frá árinu 2000 fyrir Krist til 1000 eftir Krist 99

Fjöldi málhafa 100

Gerð samískra mála 101

Beyging sagna 101

Víxl ílengd og gildi hljóđs 102

Föll 102

Afleiðsla orða 103

Tío og háttur 104

Ritháttur og málhljóð 105

Ritmál 106

Málaðstæður í samfélaginu 107

Lagasetning 107

Samíska íkennslu 108

Samíska í fjölmiðlum 109

Bókmenntir og tónlist 109

Samfélagið að öðru leyti 110

Ritaskrá 111

Vefslóðir 111 
Kalaallisut - grænlenska / Carl Christian Olsen 113

Samband tal- og ritmáls 113

Grænlenskar mállýskur 116

Einkenni grænlenska tungumálsins 117

Viðskeytamál 117

Ergatíft tungumál 117

Beygingarfræðileg tengsl 118

Föll 120

Persónuendingar 121

Viðskeyttar endingar 122

Aðalsagnir og hjálparsagnir 122

próun kalaallisut sem ritmáls 123

Staðalgrænlenska 124

Tökuorð og framandorð 125

Staða málsins 126

Ritaskrá 127

Vefslóðir 127 


\section{Formáli}

Norrcen mál með rótum og fótum er samnorrænt kennslubókarverkefni. Árið 2000 átti málnefnd Norrænu ráðherranefndarinnar frumkvæði að pví að undirbúa útgáfu norrænnar málsögu fyrir framhaldsskóla. Verkefnið var unnið í samvinnu við NORDSPRÅK, samtök norrænna móðurmálskennara og kennara sem kenna norræn mál sem erlend mál. Steen Svava Olsen var ráðinn verkefnisstjóri en lokaritstjórn var í höndum Iben Stampe Sletten.

Málráð Norðurlanda* pakkar NORDSPRÅK fyrir samstarfið og færir Iben Stampe Sletten sérstakar pakkir fyrir einstakt framlag á síðustu stigum verkefnisins.

Tilgangur pessarar útgáfu er einkum að hvetja ungt fólk til að hugleiða mikilvægi tungumálsins og auka meðvitund pess um að á Norðurlöndum sé að finna einstakt mál- og menningarsamfélag sem á rætur i sögulegum og stjórnmálalegum tengslum. Markmiðið er að efla bæði áhuga á pví sem er samnorrænt og á peim pætti móðurmálskennslunnar sem snýr að tungumálinu sjálfu og notkun pess.

\footnotetext{
* Málráð Norðurlanda var stofnað 1. janúar 2004 í stað málnefndar Norrænu ráð-
} herranefndarinnar og málnefndar Norðurlandanna.

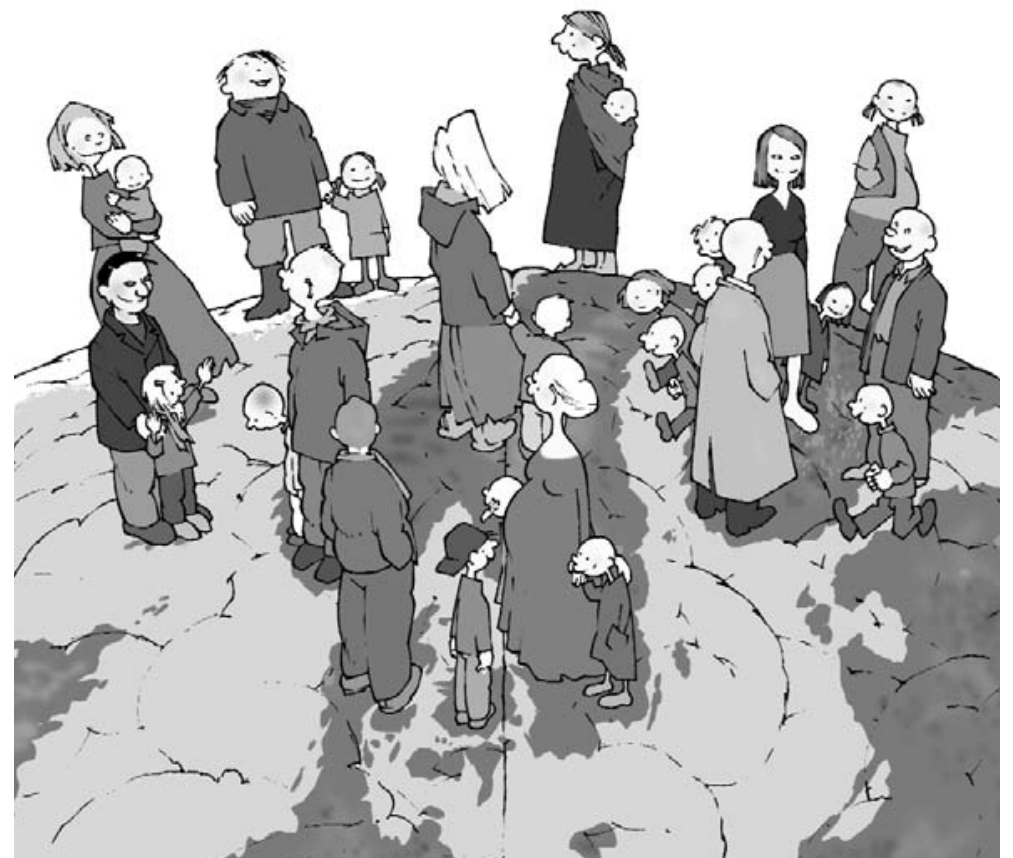


Norraen mál međ rótum og fótum er gefin út sem kennslubók á framhaldsskólastigi á öllum Norðurlöndum og er par að auki aðgengileg á netinu á sænsku, norsku, dönsku, færeysku og íslensku á vef Norrænu ráðherranefndarinnar: www.nordskol.org. Par er einnig umfangsmikið safn greina á dönsku, sænsku og norsku, m.a. um norræn tungumál og menningu, um stöðu mállýskna í mismunandi löndum og síðast en ekki síst stöðu og framtíð mála sem fáir tala. Yfirlit yfir efnið á netinu má hæglega fá með pví að lesa innganginn sem hér fer á eftir með kynningu á hverri grein. Nýjum greinum, verkefnum o.s.frv. verður sífellt bætt við.

pað er von Málráðs Norðurlanda að kennarar á öllum skólastigum geti nýtt sér bæði bókina og efnið á netinu í kennslu og stuðlað á pann hátt að pví að styrkja pað málsamfélag á öllum Norðurlöndum sem pjóðirnar sækjast eftir.

Nóvember 2004

Fyrir hönd Málráðs Norðurlanda

Guđrún Kvaran

formaður 


\section{Netútgáfa á „Norðurlandamálunum með rótum og fótum“}

Hægt er að nálgast aukna útgáfu á „,Norðurlandamálunum með rótum og fótum “ á vef Norrænu ráðherranefndarinnar á slóðinni: www. nordskol.org. Hlutar netefnisins eru fjórar greinar úr bókinni (2. kafli) og greinar um málsögu og málstefnu, flokkaðar eftir efni í 3.-7. kafla.

Í 3. kafla er, frá mismunandi sjónarhorni, sýnt fram á hvernig fortíðin birtist í nútíma málnotkun. Í 4. kafla er fjallað um samspil tungumáls og menningarvitundar. Í 5. kafla er fjallað um mállýskur og stöðu peirra í dag en í 6. kafla er umræða um áhrif ensku á Norðurlandamál. Að endingu er í 7. kafla umfjöllun um framtíð norrænna mála á tímum hnattvæðingar.

Hér á eftir er yfirlit yfir netútgáfu „Norðurlandamálanna með rótum og fótum" og stutt kynning á efni greinanna.

Allar greinarnar í 2. kafla má nálgast á íslensku, færeysku, norsku, sænsku eða dönsku, en greinarnar í 3.-7. kafla eru skrifaðar á norsku, sænsku eða dönsku. Á pann hátt er auðveldlega hægt að lesa fagtexta á öllum norrænu tungumálunum í ritinu:

- Norđurlandamálin með rótum og fótum

- Norđurlendsk mál við rótum og fótum

- Nordiske språk med røtter og føtter

- Nordiska språk med rötter och fötter

- Nordiske sprog med rødder og fødder

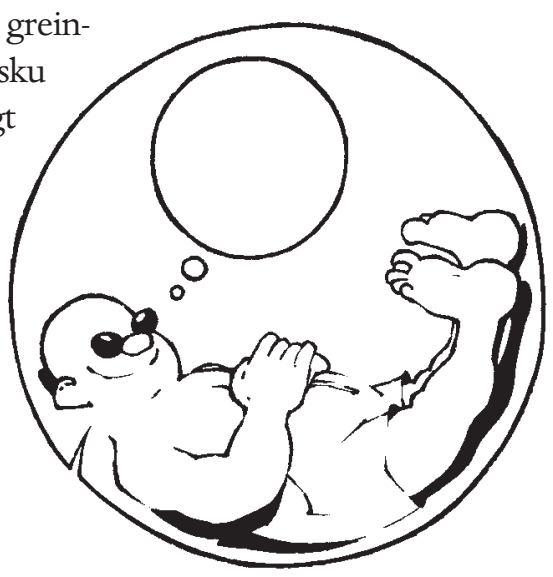




\section{Yfirlit yfir uppbyggingu netefnisins}

\begin{tabular}{|c|c|c|}
\hline & Formáli & eftir Nordens Sprogråd \\
\hline 1. kafli & Inngangur & Iben Stampe Sletten \\
\hline 2. kafli & \multicolumn{2}{|l|}{ Norræn málsaga } \\
\hline $2 a$ & Norræn tungumál að fornu og nýju & Arne Torp \\
\hline $2 b$ & Finnska & Kajsa Häkkinen \\
\hline $2 c$ & Samísk mál & Mikael Svonni \\
\hline $2 d$ & Kalaallisut - grænlenska & Carl Christian Olsen \\
\hline 3. kafli & \multicolumn{2}{|l|}{ Rætur nútímans í fortíđinni } \\
\hline $3 a$ & Om Etymologi～(á dönsku) & Zakaris Hansen \\
\hline $3 b$ & Finskan frysbox för germanska ord (á sænsku) & Birgitta Abrahamsson \\
\hline $3 c$ & Den danske tunge (á dönsku) & Kristján Árnason \\
\hline 4. kafli & \multicolumn{2}{|l|}{ Fjölbreytileiki Norðurlanda } \\
\hline $4 a$ & Sidemål nå igjen - fy faen! (á norsku) & Gunnar Simonsen \\
\hline $4 b$ & På svenska i Finland (á sænsku) & Birgitta Abrahamsson \\
\hline $4 c$ & Minoritetsspråk i Norden (á sænsku) & Marie-Louise Wentzel \\
\hline $4 d$ & De nordiske specialtegn (á norsku) & Arne Torp \\
\hline $4 e$ & Vet du noe om navn i Norden? (á norsku) & Gunnar Simonsen \\
\hline $4 f$ & Den islandske navneskik (á norsku) & Ari Páll Kristinsson \\
\hline 5. kafli & \multicolumn{2}{|c|}{ Pađ læra börnin sem fyrir peim er haft - mállýskur nútímans } \\
\hline $5 a$ & Får du tala ditt eget språk? (á sænsku) & Marie-Louise Wentzel \\
\hline \multirow[t]{2}{*}{$5 b$} & \multicolumn{2}{|l|}{ Dialektar - ei historie om dei pene, } \\
\hline & dei korrekte eller dei gale? (á norsku) & Gunnar Simonsen \\
\hline $5 c$ & Farvel til dialekterne i Danmark (á dönsku) & Lisbeth Nyborg \\
\hline $5 d$ & Findes der dialekter på Færøerne? (á dönsku) & Zakaris Hansen \\
\hline $5 e$ & Island - landet uden dialekter? (á dönsku) & Kristján Árnason \\
\hline 6. kafli & \multicolumn{2}{|l|}{ Enskan - ógn eđa auðlind? } \\
\hline $6 a$ & Om purismen (á dönsku) & Kristján Árnason \\
\hline $6 b$ & Engelsk tur-retur (á dönsku) & Lisbeth Nyborg \\
\hline $6 c$ & Om domænetab (á dönsku) & Lisbeth Nyborg \\
\hline $6 d$ & Have a nice day, hörru! (á sænsku) & Marie-Louise Wentzel \\
\hline 7. kafli & \multicolumn{2}{|c|}{ Mál eru breytingum undirorpin - en hvert stefna pau? } \\
\hline $7 \mathrm{a}$ & Hvor går språket? (á norsku) & Gunnar Simonsen \\
\hline $7 b$ & Ord på väg (á sænsku) & Marie-Louise Wentzel \\
\hline $7 c$ & Fra runer til sms (á dönsku) & Lisbeth Nyborg \\
\hline $7 d$ & Globalsprog - nationalsprog - lokalsprog (á dönsku) & Lisbeth Nyborg \\
\hline $7 e$ & Uddør de nordiske sprog? (á dönsku) & Lisbeth Nyborg \\
\hline
\end{tabular}




\section{Kynning á greinum}

Norræn málsaga (2. kafli)

Í mikilvægustu og viðamestu greininni „Norræn tungumál að fornu og nýju“ (hluti 2a) er farið yfir próunina allt frá sameiginlegum frumnorrænum uppruna fram að nútíma norrænna mála. Meðal annars er fjallað um hvað var líkt með málunum og hvað próaðist með ólíkum hætti, eins og orðaforði, orðmyndun og málfræði, og um fyrri áhrifavalda, m.a. latínu og lágpýsku. Dar að auki er rætt um hvernig nota má ættartréslíkanið og bylgjulíkanið sem verkfæri í málvísindum.

Í 2. kafla eru einnig prjár greinar: „Finnska“ (hluti 2b), „Samísk mál“ (hluti 2c) og „Kalaallisut - grænlenska!“ (hluti 2d), par sem lesandanum gefst færi á að kynnast gerð pessara mála og dregin er upp mynd af stöðu tungumálanna í peim löndum par sem málin eru töluð.

Í pessum kafla eru gefin svör við spurningum eins og: Gat fólk á Norðurlöndum einu sinni skilið hvert annað án nokkurra vandkvæða? Hvenær og hvernig breyttist frumnorræna málið í nútímamálin íslensku, færeysku, norsku, sænsku og dönsku? Og hvers vegna eru finnska, samíska og grænlenska ekki norræn tungumál?

\section{Rætur nútímans í fortíðinni (3. kafli)}

Dar á eftir koma prjár greinar sem frá mismunandi sjónarhorni sýna fram á að fortíðin lifir í nútímamálnotkun.

Hluti $3 a$. Í fyrstu greininni er fjallað um uppruna og próun orða, p.e.a.s. fræðin um sögu hvers einstaks orðs. Með orðsifjum er átt við sögu orðanna andstætt almennri málsögu. Saga orða er menningarsaga - eins og t.d. kemur fram í útskýringum orðanna ord, stakkel og ben, auk nafna landanna sem tilheyra Norðurlöndum. Málsagan er hvoru tveggja menningarsaga, og einnig saga, tengd sögu ríkjanna.

Hluti 3b. Í næstu grein er sýnt fram á hvernig finnskan hefur tekið að sér hlutverk einhvers konar „,frystikistu“ fyrir mörg frumnorræn orð sem tekin voru upp í finnska málið fyrir meira en 2000 árum. Vegna pess að finnskan hefur ekki orðið fyrir sömu hljóðbreytingum og hin málin hafa mörg tökuorðanna varðveist í upprunalegri mynd, aðeins aðlöguð finnsku.

Hluti 3c. Einn stærsti og pýðingarmesti munurinn á nútímanum og miðöldum er að fólk af öllu svæðinu, öllum Norðurlöndunum, frá Grænlandi til Álands og frá Norður-Noregi til Jótlands gat að öllum líkindum skilið hvert annað og átti sameiginlegar reglur í rúnunum. Í síðasta hluta kaflans er stutt kynning á danskri tungu, eins og samnorræna menningarmálið var kallað, og á rithöfundunum og fyrstu málvísindamönnunum sem notuðu og próuðu pað mál. 


\section{Fjölbreytileiki Norðurlanda (4. kafli)}

Hluti 4a. Tungumálið er án efa sá páttur sem gegnir pýðingarmestu hlutverki fyrir menningarlega sjálfsmynd. Dróun á norsku ritmáli var merki um sjálfstæði landsins en vegna pess að pað kom aldrei alveg í stað dönskunnar hafa í næstum 120 ár verið til tvær útgáfur af ritmáli, bókmál og nýnorska, í nokkrum útgáfum. Í fyrsta hluta kaflans „,Sidemål nå igjen ...“ (Hliðarmál enn og aftur ...) er dregin upp mynd af sérstöðu norska tungumálsins og framtíð pess rædd. Er stætt á pví að láta nemendur preyta próf bæði í aðalmáli sínu og í hliðarmálinu pegar vafasamt er að tala um tvö tungumál frá málvísindalegu sjónarhorni. Og getur verið að skiptingin auki á félagslegan ójöfnuð?

Hluti 4b. Í Finnlandi eru bæði finnska og sænska opinber mál. Sá sem ekki á auðvelt með að greina á milli tungumálsins sem Finnlandssvíar og sænskir Finnar tala og veit ekki hver munurinn á Finn- um og Finnlendingum er, pá verður sá hinn sami fróðari við að lesa hlutann „På svensk i Finland“ (Á sænsku í Finnlandi). Ekki er lengur skylda að læra bæði málin en hvað verður um tvítyngi og norræna samhygð ef sífelt fleiri velja að læra ekki sænsku?

Hluti 4c. Næsti hluti, „Minoritetsspråk i Norden“ (Minnihlutamál á Norðurlöndum), bætir við hluta myndarinnar af fjölbreytileika tungumálanna með yfirliti yfir málin sem eru móðurmál hluta íbúa Norðurlanda án pess pó að vera aðalmál, mállýskur eða innflytjendamál. Flestir vita ef til vill að samíska og rómani eru vernduð af Evrópusamningnum um svæðisbundin mál og minnihlutamál frá pví árið 1998 en hið sama á einnig við um mál kvena í Noregi, Tornedalsfinna í Svípjóð, tatara og eldri Rússa í Finnlandi og pýska minnihlutans í Danmörku.

Hluti $4 d$. Ef eitt Norðurlandamála er móðurmál manns er athygli á sérstöðu málsins vakin t.d. við pað að senda texta með póstforriti á ensku og árangurinn verður óskiljanleg súpa tákna. Í flestum tungumálum, par sem latneska stafrófið er notað, hefur verið nauðsynlegt að bæta við sértáknum. Í pessum hluta er saga hinna framandi norrænu stafa: æ/ä, ø/ö, å, p og ð rakin.

Mannanöfn eru einstök norræn sameign. Ótal börnum eru gefin nöfn sem eiga sér mörg púsund ára rætur á Norðurlöndum en ýmsar tískusveiflur, aðrar en norrænar, hafa í áranna rás haft áhrif á nafnaval og gerð nafna. Kaflanum lýkur með tveimur stuttum greinum, annars vegar almennri um nafnahefð í hverju Norðurlandanna (hluti 4e) og hins vegar á grein um pá sérstöku hefơ sem ríkir á Íslandi (hluti 4f). 
Pað læra börnin sem fyrir peim er haft - mállýskur nútímans (5. kafli) Ef Kalmarsambandið hefði ekki liðast í sundur á sextándu öld myndum við ef til vill tala um sænsku, norsku, dönsku, færeysku og íslensku sem skandinavískar mállýskur! En nú á hvert land sjálfstæutt mál og með mállýskum er átt við svæðisbundin frávik innan landamæra hvers lands eins og t.d. málið sem íbúar á Jemtalandi og í norðurhluta Svípjóðar eða íbúar á Borgundarhólmi í Danmörku tala.

Hluti 5a. Баð аð við skiljum hvert annað er ekki aðeins undir pví komið hvort við kunnum tungumál heldur einnig hver viðhorf okkar eru. Gagnkvæmur skilningur ræðst ekki af pví hvort við skiljum hvert annað heldur miklu fremur af viðhorfum okkar. Í fyrsta hluta kaflans er rætt um pað hver afstaða sé til mállýskna í Finnlandi, Svípjóð, Noregi og Danmörku og hvaða hleypidómar ríki.

Hluti $5 b$. Nú á tímum hafa mállýskur og notkun peirra - og um leið útbreiðsla - mjög mismunandi stöðu á Norðurlöndum. Margir pættir geta haft áhrif á áframhaldandi próun peirra. Ef til vill munum við sjá aukna áherslu á svæðisbundinn mismun sem mótvægi við hnattvæðinguna. Fengju mállýskur pá hugsanlega annað hlutverk? Í hlutanum „Dialektar - ei historie om dei pene, dei korrekte eller dei gale?" er rætt meðal annars um pað rými sem mállýskur fá í opinberum fjölmiðlum og afar mismunandi stefnu á Norðurlöndum pegar að pví kemur að staðla talmál. Margar spurninganna í kaflanum má nota sem kveikjur í umræður um fjölda atriða sem varða málstefnu.

Hluti 5c. Í rökdeilum skýra menn oft samband ríkismáls og mállýskna á eftirfarandi hátt: ,,Tungumál er mállýska sem hefur yfir að ráða her og flota“ (Max Weinreich). Í hlutanum „Farvel til dialekterne i Danmark“ (Mállýskurnar kvaddar í Danmörku) er stöðunni í Danmörku lýst en par hafa „her og floti“ ríkismálsins staðið sérstaklega sterkt. Sem afbrigði af talmáli er pað næstum einrátt í öllum opinberum samskiptum en mállýskurnar langmest notaðar manna í millum. Í eðli sínu finnst flestum, sem tjá sig um málið, að pað séu forréttindi að hafa vald á fleiri afbrigðum tungumálsins. Hvers vegna ætli raunveruleikinn sé pá annar?

Hluti 5 d. Á sama tíma og mállýskur eru við pað að deyja út í Danmörku lifa pær góðu lífi í miklu minna málsamfélagi eins og í Færeyjum ef til vill vegna pess að allt fram á nítjándu öld var ekki til neitt staðlað ritmál sem var samnefnari ólíkra mállýskna. Mismunandi framburður er jafnan viðurkenndur en umburðarlyndið 
nær ekki að sama marki yfir málfræðina og orðaforðann - eins og ef ákveðinn stofn orðs er af mismunandi kyni og beygist par af leiðandi á annan hátt í suðri en í norðri. Nánar er hægt að lesa um petta í hlutanum: „Findes der dialekter på Færøerne?“ (Eru talaðar mállýskur í Færeyjum?)

Hluti 5e. Á Íslandi er hneigðin í pá átt að svæðisbundinn framburður er hverfandi. Einsleitnin er ákveðin ráđgáta en stafar ef til vill af pví að hljóðkerfisbreytingar hafa frá pví á miðöldum verðið hverfandi og pess vegna er nánast sama stafsetningin notuð í nútímaíslensku og í forníslensku. Tungumál Íslendingasagnanna er á ýmsan hátt fyrirmynd nútímatalmáls og íhaldssemi málstefnunnar kemur á margan hátt í veg fyrir jafnvel lítils háttar mismun á framburði. Lesið meira um pað í hlutanum: „Island - landet uden dialekter?" (Ísland, land án mállýskna?)

\section{Enskan - ógn eða auðlind? (6. kafli)}

Tengsl Norðurlandamála innbyrðis hafa í aldanna rás haft pýðingarmikil áhrif á próun peirra. Nú á tímum eru pað einkum áhrif frá ensku sem vekja bæði jákvæða og neikvæða athygli og koma af stað margvíslegri umræðu sem oft tengist málræktarsjónarmiðum.

Hluti $6 a$. Í fyrsta hluta kaflans er hugtakið hreintungustefna kynnt en par er átt við pann ásetning að reyna að varðveita tungumálið með pví að nota og ráðleggja orðmyndir sem eru málinu eiginlegar. Aðrar orðmyndir aftur á móti eru taldar rangar og ráðlagt er að sniðganga pær. Dannig er unnt að tala um hreintungustefnu bæði hvað einstaklinginn varðar og sem lið í opinberri málstefnu. Í greininni er rætt um afstöðu og aðgerðir í pví landi sem sinnir málvöndun minnst, Danmörku, og í andstæðu pess, Íslandi.

Hluti 66 . Tímarnir breytast. Norðurlandamál taka í auknum máli við enskum aðkomuorðum og tengist pað einkum vaxandi bandarískum áhrifum á efnahag og stjórnmál eftir síðari heimsstyrjöld. Áður var pessu öðruvísi varið. Eftir að danskir og norskir víkingar höfðu rutt sér leið átti fornnorrænt og fornenskt talmál samleið í nokkur hundruð ár áður en pau blönduðust smátt og smátt. Mörg venjulegra orða í nútímaensku eru sprottin af máli sem einu sinni var talað í Dýskalandi, Danmörku og Noregi nútímans. Sögulegt samband enskunnar og norrænu er til umfjöllunar í hlutanum „Engelsk tur-retur“" (Enskan snýr aftur).

Hluti 6c. Ekkert er nýtt við pað að mál taki orð að láni úr máli peirra sem hafa völdin eða peirra sem pörf er á að eiga samskipti við - ólíkt pví að skipta út einu máli fyrir annað! Lán enskra eða 
amerískra orða á sviðum sem snerta fjölmiðla, verslun og tækni er nú orðið svo mikið að sumum finnst að pað muni kæfa pjóðmálið. Dessi hluti fjallar um tapið á sérsviðunum. Verður gripið eða er hægt að grípa í taumana? Bann við að nota ensku er óhugsandi og boð um að nota pjóðmálið er óraunhæft - en til hvaða ráða er pá hægt að grípa?

Hluti 6d. Á öllum Norðurlöndum eru unglingar aðalinnflytjendur enskra og amerískra orða og orðasambanda. Mörgum finnst peir vera allt að pví tvítyngdir og fátt mæla á móti pví að gefa talmáli heimalandsins alpjóðlegan blæ með pví að nota ensk hugtök. En hvers vegna er pað flottara að sjoppa en að fara í búðir? Hvers vegna hljóma allar pýðingar á t.d. e-mail asnalega? Hvers vegna á maður

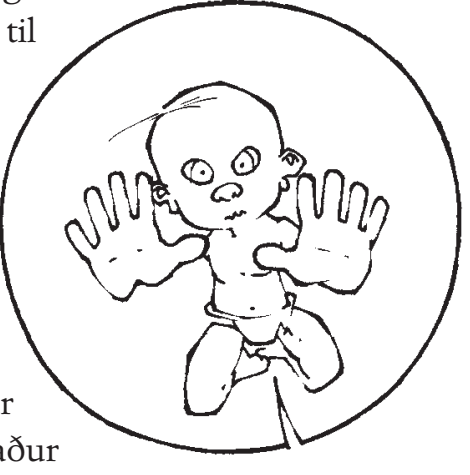
yfirleitt að hafa skoðun á hvernig fleirtalan af big pack eða disc man er á íslensku? Hlutinn „Have a nice day, hörru!" (Heyrðu, have a nice day!) veitir ekki svar við öllu en par eru fleiri spurningar og dæmi.

Mál eru breytingum undirorpin - en hvert stefna pau? (7. kafli) Hluti 7a. Öll lifandi mál eru breytingum undirorpin. Talmálið breytist pegar fólk hittist, hlustar, verður fyrir áhrifum og breytir ef til vill málnotkun sinni smávægilega. Drátt fyrir áhrif orðabóka, málnefnda og kennara breytist ritmálið einnig - en mishratt eftir löndum. Er hægt að stýra pessari próun, og hvers vegna er yfirleitt verið að reyna pað? Í fyrri hluti kaflans er spurt: „Hvor går språket?“ (Hvert stefnir málið?) og litið er til ólíkra áætlana sem gripið hefur verið til í peim tilgangi að mæta breytingunum á Norðurlöndum.

Hluti $7 b$. Tungumálið breytist æ hraðar pannig að orðabækur úreldast fljótt. Detta er pó misjafnt eftir löndum. Unnt er að flytja merkingu orðs af einu sviði yfir á annað á sama hátt og hliðarmerking getur allt í einu orðið ríkjandi. Á tímum upplýsingasamfélagsins eru breytingar svo örar að pað getur verið erfitt að fylgjast með peim. Í hlutanum „Ord på väg“ (Orð á leiðinni) er farið yfir ólíkar gerðir merkingarskipta og skilningsvanda sem getur fylgt í kjölfarið.

Hluti 7c. Saga tungumálsins nær ekki aðeins yfir próun orðaforðans, málfræðinnar og framburðarins í áranna rás heldur einnig til próunar pess efnis og peirra aðferða sem notast hefur verið við til að setja tungumálið fram og miðla pví til notenda - pað er að segja aðferða fjölmiðla. Í hlutanum „Fra runer til sms“ (Frá rúnum 
til sms) er farið yfir pann pátt sem nýir miðlar eiga í beitingu málsins, málsniði og notkun. Símskeytin, síminn, útvarpið, sjónvarpið, tölvan og farsíminn hafa öll haft áhrif á samveru- og tjáningarform fólks, svo furðu vekur. Enginn hefði t.d. getað sagt fyrir um hvaða pýðingu farsíminn hefði fyrir tilveru barna og unglinga - og hversu skringilega sem pað kann að hljóma er hægt að segja að sms-málið eigi margt sameiginlegt með rúnunum.

Hluti 7d. Í pví sem á eftir fer „Globalsprog - nationalsprog lokalsprog" (Alheimsmál - pjóðmál - staðbundin mál) er varpað fram spurningunni: Hvernig mun norrænu málunum og samnorrænum málskilningi reiða af á 21. öldinni? Fram til pessa hefur próunin á Norðurlöndum stefnt 1 átt að aðgreiningu málanna. Frá pví að norrænar pjóðir töluðu sameiginlega ,,danska tungu " hafa pær af pjóðernislegum og stjórnmálalegum ástæðum fjarlægst hver aðra að pví er tungumálið varðar. Nú til dags beinir hnattvæðingin próuninni augsýnilega í eina átt við pað að enska breiðist út sem alpjóðamál. En pessi próun er ekki ótvíræð. Við pað að enska er notuð sem eins konar „lingua franca“ virðist norrænu málsamstarfi nú ógnað en ef til vill hefur petta, pegar fram líða stundir, fremur í för með sér aukið lýðræði. Degar að pví kæmi gætu Íslendingar, Færeyingar, Finnar, Grænlendingar og Samar sem, að undanskildum sænskumælandi Finnum, hafa purft að nota erlent tungumál í norrænni samvinnu, staðið jafnfætis Dönum, Norðmönnum og Svíum.

Hluti 7e. Óttinn um framtíð norrænna mála er sérstaklega tilkominn vegna áhrifa ensku sem unglingamáls, viðskiptamáls og fjölmiðlamáls en norrænu pjóðmálin standa fyrir sínu - ennpá? Eru ekki í útrýmingarhættu. Sum samísk mál hafa horfið og um heim allan fjara mál og menning út með hraða sem við höfum ekki orðið vitni að áður. Eftir útreikningum málvísindamanna verður helmingur mála heimsins, samtals 7300 pekkt mál, horfinn eftir 100 ár. Að meðaltali deyr eitt mál út tíunda hvern dag og eftir tilkomu vefsins er hættan á útrýmingu mála meiri en nokkru sinni. Að spyrja spurningarinnar „Uddør de nordiske sprog?“ (Eru norrænu málin í útrýmingarhættu?), eins og gert er í pessum hluta, er af peim sökum mikilvægt. Dað eru löngun og hæfileikar - og tækifæri - hinna ungu til að tala málið sem er pýðingarmest fyrir örlög pess. Hver er framtíð málanna okkar? Og hvaða stöðu viljum við að norrænu málin skipi í framtíðinni?

Góða skemmtun!

býđing úr dönsku á islensku: Sigrún Kristín Magnúsdóttir 


\section{Norræn tungumál að fornu og nýju Lik og ólík mál, málaættir og skyldleiki mála}

Menn hafa ætíð tekið eftir að orð úr mismunandi tungumálum líkjast hvert öðru og gert sér hugmyndir um hvers vegna tungumál eru lík eða ólík. Í Evrópu eftir kristnitöku var álitið að allir hefðu í upphafi talað hebresku. Pað var tungumálið sem Gamla testamentið var skrifað á og par af leiðandi höfðu Adam og Eva einnig talað hebresku í Paradís. Ástæðu pess að síðar varð til ógrynni mismunandi tungumála er einnig að finna í Biblíunni, nánar tiltekið í 11. kafla í 1. Mósebók. Par er frásögnin af mönnunum sem ætluðu í sameiningu að byggja turn svo háan að hann næði til himins. Guði féll sú hugmynd ekkert sérstaklega vel í geð og pess vegna greip hann fram fyrir hendur mannanna með pví að rugla tungumálum peirra og koma í veg fyrir að peir skildu hver annan. Par með gáfust peir upp á pessu öllu og tvístruðust um alla jörðina.

\section{Sagan af Babelsturninum}

Pessi saga mun eiga rætur að rekja til risaturns sem tilheyrði musterisbyggingunum í borginni Babýlon við Efrat. Nafnið Babýlon pýðir „Hlið guðanna“ en gyðingarnir túlkuðu pað eins og mynd af hebresku sögninni balal, sem pýðir að rugla, og par með varð goð- sögnin um hinn svokallaða Babelsturn til. Orðatiltækið babelsk ringulreið = ,kaos', sem er til í mörgum evrópskum tungumálum, gefur til kynna pær aðstæður sem sköpuðust eftir að Guð greip inn í og stöðvaði byggingu turnsins með pví að rugla tungumálum mannanna.

Kenningin um að hebreska hafi verið frummálið er ekki sú eina sem komst á kreik fyrr á tímum. Í stórkostlegu verki í premur bindum, sem ber titilinn Atlantica, setti sænski vísindamaðurinn Olof Rudbeck (1630-1702) fram kenningu um að eyríkið Atlantis, sem forn- 
aldarheimspekingurinn Platon hélt fram að hefði legið í Atlantshafinu áður en pað sökk á einni nóttu, hafi í raun og veru verið Svípjóð. Enn fremur taldi Rudbeck að sænska væri frummálið sem gríska, latína og hebreska ættu rætur að rekja til.

Menn skildu fljótlega að petta var að minnsta kosti jafnótrúlegt og ólíklegt og kenningin um Atlantis. Degar fimmtíu árum síðar gerði landi Rudbecks, Olof von Dalin, gys að draumórum hans á pennan hátt (skriftin er færð í nútímabúning og tilvitnunin pýdd á íslensku):

Nafn Adams er hrein sænska: Adam var skapaður af moldu, af jörðu. Dað er Av damm (sænska damm = jörð). Degar V er numið á brott úr Avdam verður Adam eftir.

Eva er einnig hrein sænska. Degar maðurinn vaknaði og sá fagra konu sína án svo mikils sem fíkjublaðs er skiljanlegt að hann hafi orðið undrandi og sagt: He! Hva? Og úr peim tveimur orðum verður um leið til Heva?

Pað var ekki auðvelt að sanna kenninguna um að öll mál ættu uppruna sinn að rekja til hebresku - og síðar kom í ljós að hún var heldur ekki rétt. En áður en fram kom vísindaleg aðferð, sem hægt var að nota til pess að sýna fram á hvort eða hvernig tungumál voru skyld, var heldur ekki hægt að setja fram rök gegn slíkum kenningum sem sýndu að hvorki hebreska né sænska væru frummálið sem öll önnur mál í heiminum ættu rætur að rekja til.

Slíka aðferð fundu menn hins vegar í byrjun nítjándu aldar eftir að hafa uppgötvað pað sem kallað er skyldleiki mála af sameiginlegum uppruna. Með hinum svokölluðu sögulegu samanburðarmálvísindum varð til nákvæmt verkfæri til pess að staðfesta hvernig mál verða lík. раð getur nefnilega stafað af:

1. almennum aðstæðum í máltökuferlinu, eins og pegar orð eins og mamma og pabbi eru næstum alltaf hin sömu um allan heim,

2. svokölluðu láni, eins og pegar upprunalega gríska orðið demokrati (lýðræði) eða arabíska orðið alkohol (áfengi) finnast einnig víða annars staðar í heiminum,

3. pvi að tungumál, sem í dag geta verið afar ólík, hafa próast frá sameiginlegum uppruna með agnarsmáum stökkum hjá mörgum kynslóðum.

Aðeins í síðasta tilvikinu er um að ræða skyldleika mála af sameiginlegum uppruna. 


\section{Sögulega samanburðaraðferðin}

Ef útnefna ætti eitt ákveðið ár sem upphafið að sögulegum málvísindum, eins og við pekkjum pau í dag, hlyti pað að vera árið 1786. pað ár hélt breskur sérfræðingur í tungumálum Austurlanda, Sir William Jones, fyrirlestur fyrir The Royal Asiatic Society í Kalkútta á Indlandi, par sem hann ræddi m.a. um forna indverska málið sanskrít á eftirfarandi hátt:

The Sanskrit language, whatever its antiquity, is of a wonderful structure; more perfect than the Greek, more copious than the Latin, and more exquisitely refined than either; yet bearing to both of them a strong affinity, both in the roots of verbs and forms of grammar, than could possibly have been produced by accident; so strong, indeed, that no philologer could examine the Sanskrit, Greek and Latin, without believing them to have sprung from some common source, which, perhaps, no longer exists.

Hugsunin, sem Jones varpar fram, er sú að fjöldi mála, sem fyrir mörgum púsundum ára voru ólík, hafi einu sinni, enn lengra aftur í fortíđinni próast af sameiginlegu fornmáli sem, ,perhaps, no longer exists", eins og hann segir - hann hefði alveg eins getað sleppt fyrirvaranum ,,perhaps“, en annars var hugmyndin alveg rétt eins og í ljós kom áđur en langt um leið.

Fyrirlesturinn vakti einnig athygli í Evrópu og fljótlega voru málvísindamenn farnir að reyna að finna hvernig hægt væri með ströngum vísindalegum aðferðum að færa sönnur á samhengið sem Jones hafði bent á. Mikilvægt er að nefna bjóðverjana Franz Bopp (17911867) og Jacob Grimm (1785-1863) en vinna peirra og annarra lagði grundvöll að rannsóknum síđari tíma á indóevrópskum málum. Á Norðurlöndum var einnig heimskunnur vísindamaður sem naut sömu virðingar og fyrrnefndir pjóðverjar, Daninn Rasmus Rask (1787-1832), sem á stuttum lífsferli sínum stundaði ekki einungis grunnrannsóknir á indóevrópsku og pá ekki síst norrænum málum heldur hafði hann líka áhuga á málum utan indóevrópsku málaættarinnar, m.a. finnsku og samísku.

Á sama tíma og sögulega samanburðaraðferðin próaðist átti sér stað feikileg próun innan náttúruvísindanna - ekki síst líffræði - og par veldur próunarkenning Darwins ákveðnum páttaskilum. Liffræðingar og málvísindamenn fóru nokkurn veginn samtímis að nota svokallað cettartré til pess að sýna fram á hvernig núlifandi 


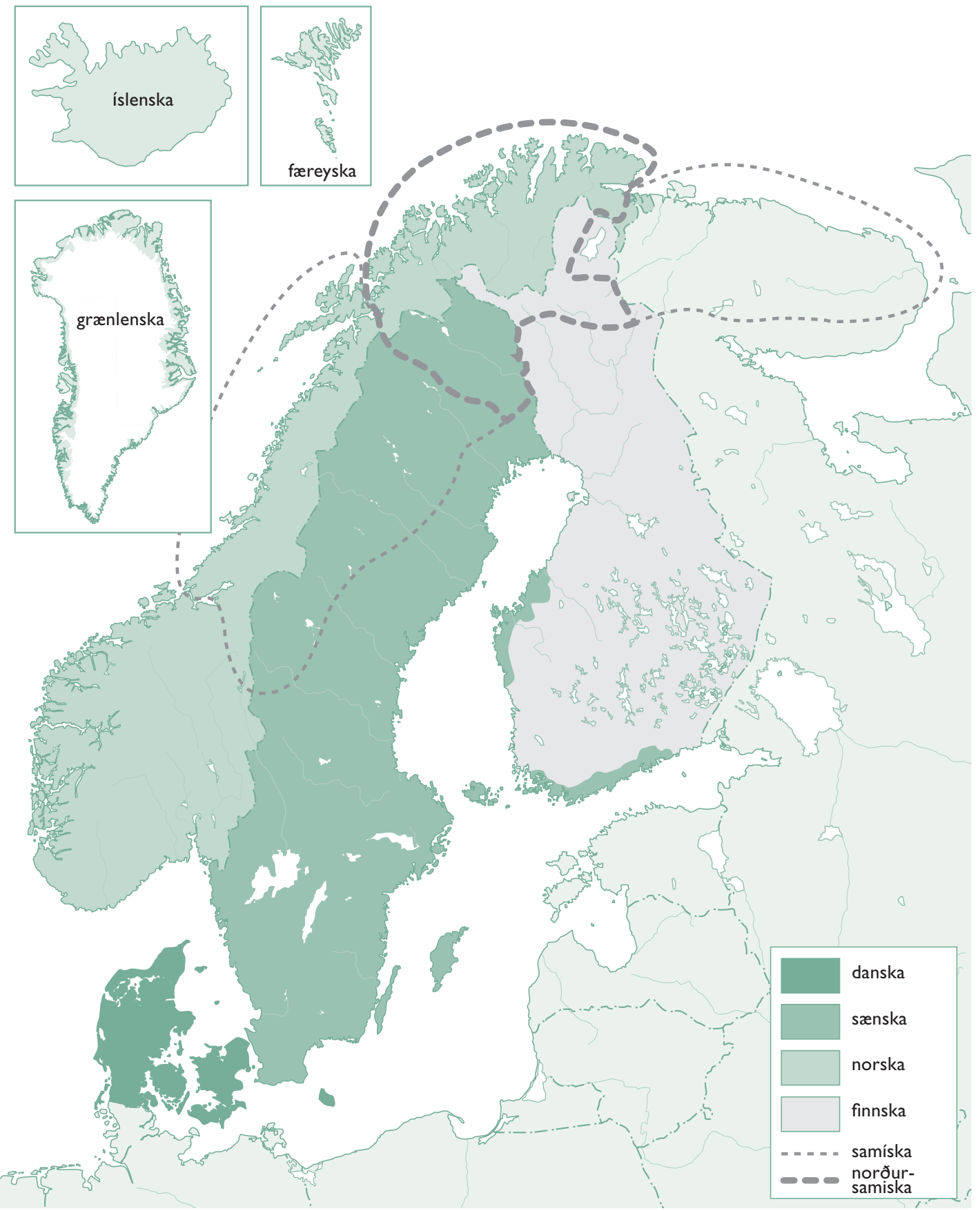

Mynd 1: Norðurlönd - landfræðilegt svæði og hefðbundin mál 
lífverur og nútímamál hefðu próast af fyrri tegundum. Dessi ættartré hafa, ólíkt venjulegum trjám í skóginum, rótina oftast efst á meðan greinarnar vaxa niður á við (sjá t.d. mynd 4 hér að aftan).

\section{Norðurlandamálin: Prjár ættir - mörg mál}

Á Norðurlöndum eru bæði náskyld mál og mál sem tilheyra afar ólíkum fjölskyldum. Pólitíska landfræðilega svæðið, sem kallað er Norðurlönd, nær allt frá Grænlandi í vestri yfir Ísland og Færeyjar að Finnlandi í austri - með Danmörku, Noreg og Svípjóð miðja vegu. Á pessu stóra svæði eru töluð mál sem að hluta til eiga sameiginlegan sögulegan uppruna en að hluta til er ekki (mynd 1).

Frá lokum átjándu aldar hafa málvísindamenn sýnt að mál breytast með tímanum á pann hátt að hægt er að setja fram svokölluð hljóðlögmál um hvernig hljóðin á einu stigi málpróunarinnar tengjast fyrri og síðari stigum sama tungumáls. Hljóđlögmál eru meðal mikilvægustu verkfæra sögulegu samanburðaraðferðarinnar vegna pess að með tilstilli pessara lögmála hefur verið unnt að benda á allnokkrar málafjölskyldur, p.e. hóp af málum sem hafa próast frá sameiginlegum uppruna. Síðar verður litið á hvernig pessi lögmál virka í reynd.

Fyrst er rétt að athuga hvernig hægt er að nota hljóðlíkindi til pess að sýna fram á mismunandi málaættir. Berum saman fimm fyrstu töluorðin í fjórum tungumálum úr indóevrópsku málaættinni, norsku, pýsku, ensku og frönsku, og svo sömu töluorðin í samísku, finnsku og ungversku sem tilheyra úrölsku málaættinni:

\begin{tabular}{lllllll}
\hline \multicolumn{3}{l}{ indóevrópsk mál } & & \multicolumn{4}{c}{ úrölsk mál } \\
\hline norska & pýska & enska & franska & samíska & finnska & ungverska \\
\hline en/ein & eins & one & un & okta & yksi & egy \\
to & zwei & two & deux & guokte & kaksi & kettö \\
tre & drei & three & trois & golbma & kolme & három \\
fire & vier & four & quatre & njeallje & neljä & négy \\
fem & fünf & five & cinq & vihtta & viisi & öt \\
\hline
\end{tabular}

Mynd 2: Fimm fyrstu töluorðin í nokkrum indóevrópskum og úrölskum málum 
Sjá má að tölurnar líkjast hver annarri mikið í fyrstu premur málunum vegna pess að pau tilheyra sömu grein á indóevrópska „trénu“, hinni germönsku. Franska tilheyrir aftur á móti rómönsku greininni sem hefur próast úr latínu, sem tilheyrir hinum svokölluðu itölsku málum. Frönsku töluorðin eru ekki eins lík og töluorðin í fyrstu premur dálkunum en pó má sjá að pau líkjast peim dálítið. Úrölsku töluorðin eru hins vegar gerólík peim indóevrópsku en sýna aftur á móti viss innbyrðis líkindi. Á meðal úrölsku málanna sjáum við að samíska og finnska hljóta að tilheyra annarri grein en ungverska.

Ef um væri að ræða mismunandi málaættir væri pað pó bæði óvænt og ósennilegt að töluorðin væru lík og eins og sjá má eru pau pað ekki heldur. Indóevrópska og úralska eru sem sagt tvær ólíkar málaættir einmitt vegna pess að pað er ekki hægt að sýna fram á sameiginlegan uppruna með hljóðlögmálum.

Innan sömu málaættar má hins vegar nota hljóðlögmál til pess að sýna fram á mismunandi undirflokka. Eins og sjá má af pessum dæmum geta núlifandi meðlimir í málaætt verið afar mismunandi, alveg eins og fjarskyldir ættingjar í líffræðilega heiminum. Ef pau tilheyra sömu ætt hafa pau próast úr einu og sama „frummáli“. Um petta frummál eru oft ekki til nein raunhæf dæmi í skriflegum heimildum eða á öðrum minnismerkjum, rétt eins og við vitum ekki heldur mikið um hvernig forfeður okkar langt aftur í fortíð litu út.

Í málvísindum geta vísindamenn með nokkurri nákvæmni samt sem áður endurgert slík ,frummál“ með aðstoð sögulegu samanburðaraðferðarinnar. Sú aðferð byggist m.a. á pví að bera saman núlifandi mál og elstu form peirra og pá sérstaklega pau sem við höfum raunveruleg dæmi um í formi skriflegra heimilda. Í dag eru á Norðurlöndum mál af premur mismunandi ættum og sambandið milli einstakra meðlima í hverri ætt er hægt að setja fram á eftirfarandi hátt (sjá mynd 3):

pað er mikilvægt að greina á milli norræenu málanna - sem er samheiti yfir norðurgermanskan undirflokk indóevrópsku ættarinnar, p.e. dönsku, sænsku, norsku, færeysku og íslensku - og Norðurlandamálanna sem einnig ná yfir mál úr bæði úrölsku ættinni, p.e. samísku og finnsku, og úr eskimóísk-aleúsku málaættinni, p.e. grænlensku.

Nánar verður fjallað um indóevrópsku málaættina síðar en fyrst koma nokkur orð um hinar tvær málaættirnar. 


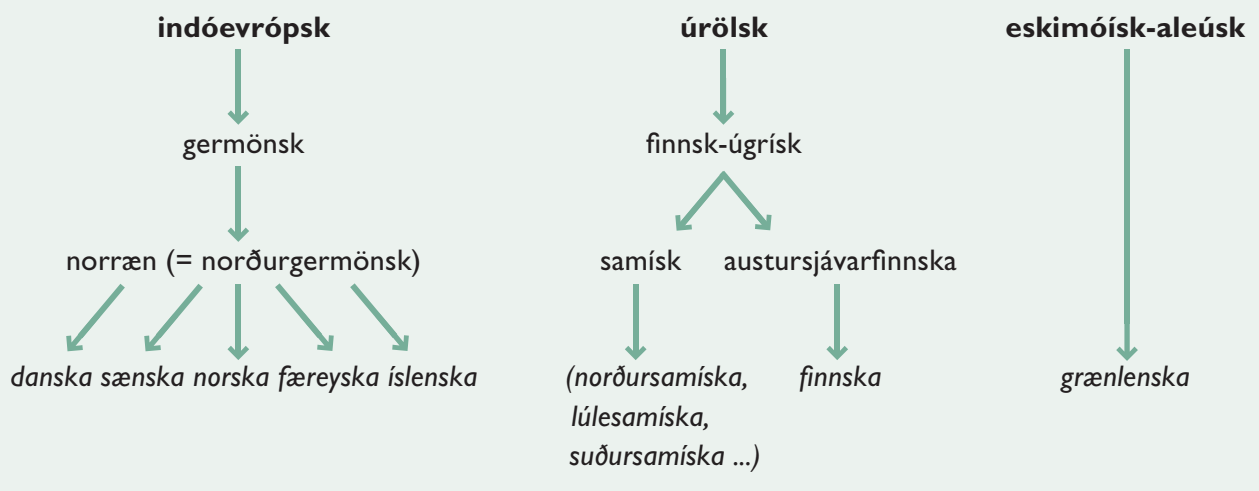

Mynd 3: Málafjölskyldur og Norðurlandamálin

Grænlenska er af eskimóisk-aleúsku ættinni vegna pess að Grænlendingar eða inúítar, eins og peir nefna sig sjálfir, eiga sína mállegu ættingja í vestri - í Norður-Ameríku - yfir Norður-Kanada og Alaska, til Aleúteyja fyrir sunnan Beringshafið (sjá grein um grænlensku).

Málaættarnafnið úralska gefur til kynna að málvísindamenn álíti að tungumál Finna og Sama eigi rætur sínar að rekja til nágrennis Úralfjalla í Rússlandi. Úralska málaættin nær ekki aðeins yfir margs konar litla málaflokka í Rússlandi heldur einnig stórt evrópskt mál, ungversku, auk eistnesku sem er bæði mállega og landfræðilega næsti nágranni Finna. Reyndar eru finnska og eistneska svo náskyldar að málin eru að hluta til auðveldlega gagnkvæmt skiljanleg. En skilningurinn er oftast aðeins á annan veginn - Eistarnir eru miklu duglegri við að skilja finnsku en Finnar eistnesku! (sjá grein um finnsku).

Hið sama á einnig við víða annars staðar í heiminum að fólk í litlu málsamfélagi á auðveldara með að skilja „stóra“ málið en öfugt. Detta sjáum við m.a. á sambandinu á milli lítilla og stórra norrcenna mála. Deir allra duglegustu eru peir sem tilheyra minnsta norræna málsamfélaginu eða um pað bil 55.000 Færeyingar. Deir skilja allvel öll norræn mál - að meðtalinni dálítilli íslensku. Aftur á móti reka Svíar oftast lestina en peir mynda stærsta norræna málsamfélagið, næstum pví níu milljónir. Rannsóknir hafa sýnt að Svíar skilja bæði dönsku og norsku verr en Danir og Norðmenn skilja sænsku (sjá grein um samísku).

Í peim skilningi, sem við leggjum í tungumál, er vart hægt að reikna með samísku sem aðeins einu máli. Ólíkustu samísku „mállýskurnar" eru eins ólíkar og til dæmis skandinavíska og pýska, p.e.a.s. 
að fólk, sem talar pessar mállýskur, skilur ekki hvað annað (sbr. kaflann um samísku). Af pví leiðir að Samar frá mismunandi samískum málsvæðum geta oftast ekki talað saman á samísku en verða að notast við sameiginlegt erlent tungumál. Í reynd er pað oftast málið sem flestir tala í viðkomandi landi (norska, sænska, finnska eða rússneska). Sameiginlegt erlent tungumál af slíkum toga, sem talað er af fólki sem á ólík móðurmál, er kallað lingua franca.

\section{Lingua franca}

Lingua franca er í dag notað um hvert pað mál sem fólk með mismunandi móðurmál notar í samskiptum sín í milli án pess að̃ nokkurt af pví eigi petta tiltekna mál að móðurmáli. Nú á tímum er pað oftast enska sem hefur petta hlutverk í stórum heimshlutum en í peim ríkjum, sem áđur tilheyrðu Sovétríkjunum, er pað rússneska. Í Afríku geta tungumál gömlu nýlenduveldanna (enska, franska og portúgalska) bjónað pessu hlutverki en einnig staðbundin afrísk mál (t.d. svahíli í Austur-Afríku).

Bókstaflega pýðir lingua franca samt sem áđur ,franskt mál', en petta heiti átti upprunalega ekki við pað sem við pekkjum sem frönsku heldur blendingsmál, p.e.a.s. einfalt hjálparmál sem enginn hefur sem móðurmál en er notað pegar fólk, sem ekki á sameiginlegt móðurmál, talar saman. Hin upprunalega lingua franca var blendingsmál með afar einfaldri málfræði, byggt á orðum úr mismunandi rómönskum málum (sérstaklega próvönsku, ítölsku og spænsku) og sem var notað í viðskiptum kringum Miðjarðarhafið í mörg hundruð ár frá miðöldum og fram á nítjándu öld. Nú á tímum eru til mörg blendingsmál í öđrum heimshlutum og eru pau oftast byggð á orðum úr tungumálum evrópsku nýlendnanna (einkum ensku og frönsku).

Fyrr á tímum var einnig til blendingsmál í Skandinavíu, rússanorska, sem var notað í svokallaðri „pomorverslun“ í Norður-Noregi á milli Rússa og Norðmanna frá átjándu öld allt fram að fyrri heimsstyrjöld. Orđin í rússanorskunni voru að hluta til sótt í rússnesku og hluta til norsku en einnig ýmis önnur evrópsk mál (ensku, pýsku og hollensku).

Pomor er rússneskt orð sem pýða má á íslensku sem strandbúar eđa fólk sem býr við hafið.

Tilvísanir í vefföng par sem hægt er að lesa meira um lingua franca, pomorverslun og rússanorsku eru á bls. 74 . 
рað kemur ekki sérstaklega á óvart að tungumál sem eiga engan sannanlegan sameiginlegan uppruna séu afar ólík. En innan einstakra málaætta er oft mikill munur á ýmsum „,fjölskyldumeðlimum“. Petta á sérstaklega við innan úrölsku ættarinnar og ekki síour innan indóevrópsku ættarinnar sem nú verður athuguð nánar.

\section{Indóevrópska málaættin}

Sá sem fyrstur teiknaði ættartré indóevrópsku málaættarinnar var Djóðverjinn August Schleicher (1821-1868). Ættartré hans leit svona út:

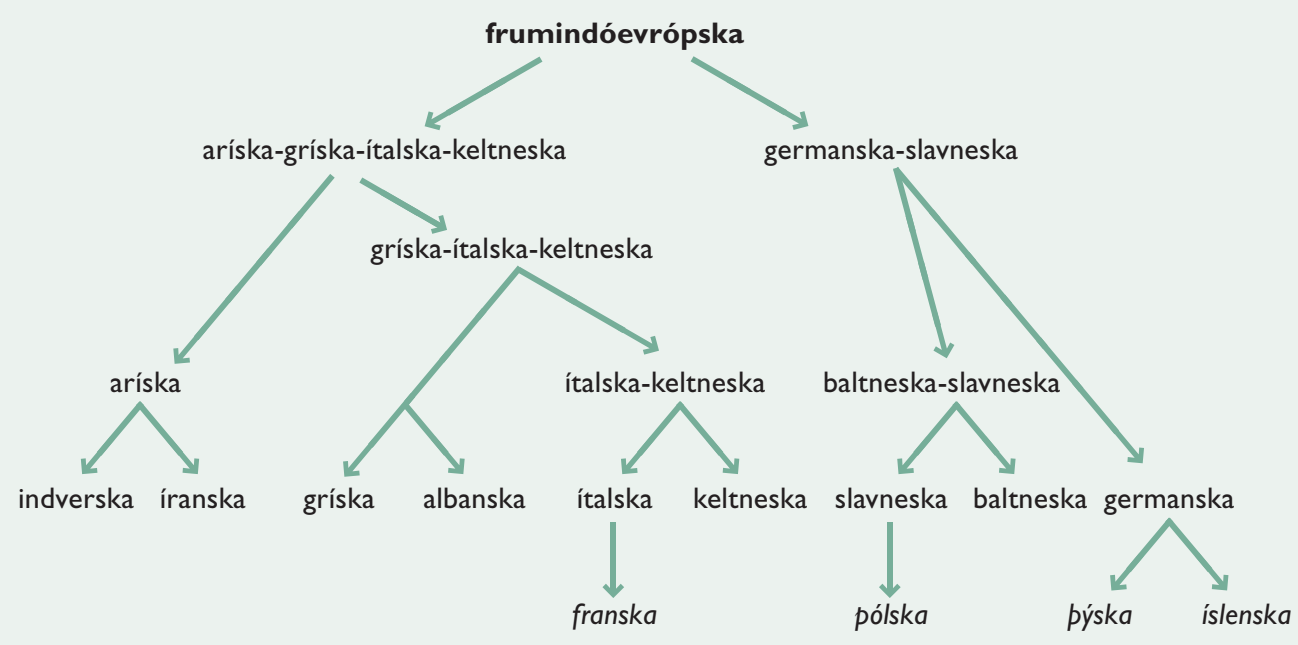

Mynd 4: Hið indóevrópska ættartré Schleichers. Nútímamálin fjögur, sem standa skáletruð neðst á „,trénu“, eru ekki með hjá Schleicher; peim hefur verið bætt við hér. Hvers vegna einmitt pessi mál hafa verið valin sem dæmi verður ljóst af framhaldinu.

Detta ber að skilja á pann hátt að Schleicher taldi að frumindóevrópska hafi fyrst skipst í tvær „greinar“ - ,arísk-grísk-ítölsk-keltnesku“ greinina og „germansk-slavnesku“ greinina - Eftir petta hafi síðan hver pessara flokka skipst áfram í tvennt og svo koll af kolli. Hver pessara skiptinga var afleiðing pess að pað hafði komið fram mismunur á mállýskum innan upprunalega einslits indóevrópsks 
frummáls. Slíkur mállýskumunur verður oftast til eftir að hlutar af upprunalegum pjóðflokki yfirgefa „,frumheimilið“ (ekki er vitað hvar pað hefur verið) og taka sér bólsetu á afar mismunandi stöðum.

\section{Indóevrópska frummálið}

Uppruni indóevrópsku málanna er enn óljós, bæði hvað varðar tíma og stað. Algengast er að líta svo á að öll indóevrópsku málin eigi rætur að rekja til eins frumforms sem var eitt samræmt mál fyrir u.p.b. 5-6000 árum og var talað af hópi fólks sem bjó einhvers staðar fyrir norðan eða sunnan Svartahaf - um pað eru vísindamenn ekki sammála.

Fyrsti hópurinn, sem yfirgaf ,frumheimilið“, var sennilega sá sem seinna varð kunnur sem hettítar, forn menn- ingarpjóð austarlega í Litlu-Asíu. Sumir vísindamenn álíta að pessi brottflutningur hafi orðið fyrir að minnsta kosti 4000 árum. Seinna hafi mismunandi hópar - indóíranir, slavar, keltar og germanir - reikað í mismunandi áttir, pannig að smám saman breiddust indóevrópsku málin um alla Evrópu og stóran hluta Asíu. Á síđari nýlendutímum hafa indóevrópsk mál eins og enska, spænska, franska og portúgalska breiðst út til allra heimsálfa á jörðinni.

Hinar svokölluðu landfrceðilegu mállýskur - p.e.a.s. landfræðilega mismunandi talmál eða pað sem við köllum venjulega mállýskur verða oftast til vegna einhvers konar náttúrulegra hindrana. Dað sem skilur að mállýskur eru fyrst og fremst miklar landfræðilegar vegalengdir eða náttúrumyndanir eins og há fjöll og ófærir skógar eða mýrlendi sem gera hvers konar dagleg samskipti erfið. Рað er ekki fyrr en með nútímafjölmiðlum - ekki síst rafrænum - að við, í fyrsta sinn í sögunni, getum átt samskipti við hvern sem er án tillits til náttúrulegra hindrana eða fjarlægðar. Fólksflutningar til fjarlægra staða fyrr á tímum höfðu pess vegna óhjákvæmilega í för með sér að til urðu mismunandi mállýskur sem með tímanum urðu ólíkari og komu smám saman í veg fyrir málsamskipti á milli mismunandi hópa brottfluttra.

Ef við lítum á „tréð“ á mynd 4 sem lýsingu á pví sem er raunverulega líkt og ólíkt í mismunandi málum í dag er sennilegt að líkanið standist nokkuð vel. Mál, sem eru á sömu grein, eru líkari en 


\section{Málpróun: Villa eftir villu endalaust ...}

Ef pjóðarbrot, sem upphaflega talaði sama mál, skiptir sér í marga hópa sem ekki hafa nein samskipti sín á milli mun pað smám saman hafa mikil áhrif á málið. Og aðalástæða pess er sú einfalda staðreynd að fólk lifir ekki að eilífu. Par með er hægt að segja að málið mótist aftur hjá hverri kynslóð, pað verður til í bernsku á grunni pess máls sem barnið heyrir í umhverfi sínu. Pá er ekkert merkilegt að til verđi smávegis mismunur á pví máli, sem eldri kynslóđin talar, og pví máli sem börnin ,búa til““. Frá sjónarhorni eldri kynslóðarinnar talar unga fólkið ekki „,rétt“ mál en ef nógu margir ungir gera sömu „villuna“ verður „villan“ smám saman ný regla.

Sem raunverulegt dæmi getum við tekið orðið tak, sem í dag getur haft tvenns konar afar ólíka merkingu í norsku. Við tölum um tak (pak) á húsi og við getum ,ta et tak“ (tekið taki) ef gripið er fast um eitthvað. Í eldri norrænu voru petta tvö orð sem voru borin fram á mismunandi hátt: Um að grípa fast í eitthvað var sagt tak en um húspak var sagt pak, með sama hljóði fremst í orđinu og th-hljóðið í enska orðinu thing. Öll skandinavísku málin hafa fyrir löngu síđan tapað th-hljóðinu og pað gerðist að mestum hluta pegar á miðöldum. Petta er dæmi um ,framburðarvillu“ sem festi rætur um alla Skandinavíu. Á Íslandi hefur mismuninum á $p$ og $t$ aftur á móti verið haldið svo að par er ennpá talað um tak (að grípa í eitthvað) og pak (húspak).

En tungumálið hefur frá fornu fari einnig breyst á Íslandi - aðeins ekki næstum pví jafnmikið og í Skandinavíu. Dæmi um pað er sérhljóđinn $y$, sem orðinn er að $i$ i íslenskum framburđi, pannig ađ Íslendingar bera nútíð sagnanna biter og flyter fram eins og rímorð: bítur og flítur (aftur á móti eru pær skrifaðar á mismunandi hátt: bítur og flýtur). Par með getum við slegið pví föstu að fólk í Skandinavíu hafi gert sumar „villur“ sem ekki hafa fest rætur á Íslandi á meðan Íslendingarnir hafa gert aðrar „villur“ sem ekki eru algengar í Skandinavíu.

Mergur málsins er sem sagt sá að pað eru ekki allir sem gera sömu ,,villurnar" pótt tungumálið hafi í upphafi verði líkt. Ef fólk býr nógu lengi aðskilið mun óhjákvæmilega verða mismunur á máli pess vegna pess að fólk gerir mismunandi „villur“ við ólíkar aðstæður.

mál sem tilheyra mismunandi greinum. Franska, pólska og pýska eru mjög ólík mál, prátt fyrir að pýskaland sé bæði nágrannaland Frakklands og Póllands. Ástæða pess, að tungumálin eru svo ólík, er að greinarnar, sem pau tilheyra, skiptust fyrir afar löngu. Dau hafa pess vegna haft langan tíma til pess að próa sérkenni sín. 
Dýska og íslenska eru ekki heldur mál sem eru gagnkvæmt skiljanleg en pau eru líkari hvort öðru en málin í nágrannalöndunum premur prátt fyrir mikla landfræðilega fjarlægð á milli býskalands og Íslands. Fyrst pýska og íslenska eru svona lík mál hlýtur pað að stafa af skyldleikanum, bæði eru germönsk mál.

\section{Ættartréð og norræn mál}

Séu norrænu málin sett inn í ættartréð fæst niðurstaða sem er ekki alveg í samræmi við pað sem venjulega er talið líkt og ólíkt með málunum fimm:

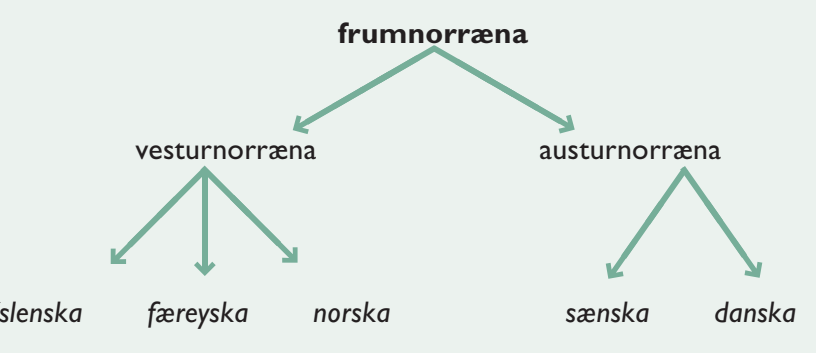

Mynd 5: Skipting norrænna mála á ættartrénu

Ef petta tré er „lesið“ á sama hátt og indóevrópska tréð í kaflanum hér á undan ætti norska að líkjast íslensku og færeysku meira en sænsku og dönsku. Detta vita allir Norðmenn að er ekki rétt. Norðmenn skilja dönsku og sænsku frekar auðveldlega, sænsku meira að segja næstum jafnvel og móðurmál sitt, á meðan bæði færeyska og íslenska eru framandi tungumál. Í pessu tilviki er pað ekki rétt að mál, sem eru nálægt hvert öðru á ,greinunum“, líkist einnig hvert öðru á pann hátt að pau séu gagnkvæmt skiljanleg - pað á nefnilega ekki við „kvistina“ prjá ( islensku, fcereysku og norsku) á vesturnorrænu greininni. Samtímis eru kvistirnir tveir (scenska, danska) á austurnorrænu greininni bæði gagnkvæmt skiljanlegir og skiljanlegir gagnvart einum af vesturnorrænu kvistunum (norsku). Hér er pví ekki hægt að nota ættartréð sem vegvísi til pess að finna hvað er líkt og ólíkt með nútímamálum, enginn fullvita maður myndi halda pví fram að norska líktist íslensku og færeysku meira en sænsku og dönsku. 
Hvers vegna rætt er um „,austurnorrænu“ gagnstætt „,vesturnorrænu“ verður athugað nánar seinna. Sökum ákveðinna sögulegra ástæðna er ekki rétt að nota ættartréð til pess að sýna fram á hvað er líkt og ólíkt með norrænum nútímamálum. En fyrst skulum við huga betur að stórum flokki norrænna mála sem tilheyrir indóevrópsku málaættinni, germönsku málunum.

\section{Germanska málaættin}

Í dag dreifast germönsk mál út um mestan hluta jarðarinnar. Đað gerðist fyrst og fremst vegna seinni tíma nýlendna eða á rúmlega síðustu 300 árum. Drátt fyrir að pessi mál hafi upprunalega verið töluð í Evrópu eru nokkur peirra töluð mest utan Evrópu - pað á ekki síst við um heimsmálið svo kallaða, ensku.

Reyndar er eitt germanskt mál aðeins talað í suðurhluta Afríku, pað er að segja afríkanska. Đað er fyrst og fremst móðurmál hinna svo kölluðu Búa sem fluttu frá Hollandi á petta svæði upp úr miðri sautjándu öld.

Jiddiska, evrópska gyðingamálið, byggist aðallega á pýsku en einnig nokkrum undirstöðuatriðum úr hebresku. Fyrir seinni heimsstyrjöld töluðu langtum fleiri pað en nú. Á priðja áratug síðustu aldar er reiknað með að u.p.b. 7 milljónir manna í Evrópu hafi talað pað og á fjórða áratug peirrar aldar eitthvað á milli 1 og 11/2 milljón manna í Bandaríkjunum. Spurningarmerkin í töflunni merkja að upplýsingar um fjölda vanti.

\begin{tabular}{|c|c|c|}
\hline mál & $\begin{array}{r}\text { móđurmál manna } \\
\text { í Evrópu }\end{array}$ & $\begin{array}{r}\text { móđurmál manna } \\
\text { utan Evrópu }\end{array}$ \\
\hline enska & 60.000 .000 & 400.000 .000 \\
\hline pýska & 98.000 .000 & ? \\
\hline hollenska & 21.000 .000 & ? \\
\hline sænska & 9.000 .000 & ? \\
\hline afríkanska & ? & 6.000 .000 \\
\hline danska & 5.300 .000 & ? \\
\hline norska & 4.500 .000 & ? \\
\hline frísneska & 400.000 & ? \\
\hline jiddíska & ? & 400.000 \\
\hline íslenska & 280.000 & ? \\
\hline færeyska & 55.000 & ? \\
\hline
\end{tabular}

Mynd 6: Germönsk mál - fjöldi peirra sem hefur pau að móðurmáli 
Hvernig pessi ellefu mál hafa próast frá hinu upprunalega indóevrópska frummáli er hægt að lýsa með aðferðinni sem notuð er í sögulegum samanburðarmálvísindum. Og par er unnið út frá lögmálinu um að hljóðbreytingar séu ekki tilviljunarkenndar heldur stýrist pvert á móti af mjög ákveðnum hljóðlögmálum.

\section{Germanska hljóðfærslan}

Mikilvægasta einkennið, sem skilur germanska málaflokkinn frá öðrum í indóevrópsku málafjölskyldunni, er hljóðlögmál sem kallað er germanska hljóðfcerslan. Dað er vegna pessarar hljóðfærslu að orðin far og fe (fé) byrja á fí öllum norrænum málum en t.d. sömu orð í latínu byrja á p: pater og pecu (borið fram / peku/ með ú eins og í dönsku eða pýsku).

Eins og sjá má eru norrænu nútímaorðin far og fe (fé) frekar ólík latnesku orðunum pater og pecu. En sé farið aftur á bak í málsögunni má sjá að samsvarandi germönsk orð líkjast peim latnesku meira og meira. Fyrir púsund árum - á fornnorrcenu - hétu pau t.d. fadir og fé og ef farið er fimm hundruð eða púsund ár lengra aftur í söguna - í frumnorrcenu eða frumgermönsku - hétu pau fađer og fehu, og pá er bilið á milli peirra og pater og pecu um leið miklu minna.

Takið samt eftir að pessar elstu germönsku orðmyndir byrja á $f$; annars hefði pað sýnt að pær væru ekki germanskar heldur hlytu pær að vera lán frá annarri grein innan indóevrópsku málaættarinnar - eða frá allt annarri málaætt.

\section{Fornnorræna og frumnorræna}

Heitið fornnorræna er venjulega notað um málið bæði i Noregi og á Íslandi frá pví um 900 og fram til u.p.b. 1350. Pá voru málin í pessum tveimur löndum næstum pví eins vegna pess að Íslendingar eru að uppruna norskir útflytjendur - sérstaklega frá VesturNoregi og pað sama gildir um Færeyinga. Nútímaíslenska og -færeyska eiga pess vegna margt sameiginlegt með mállýskunum í Vestur-Noregi. Ef til vill stafar petta að einhverju leyti af sameiginlegum uppruna eða, eins og aðrir halda fram, síðari tíma samskiptum við Noreg.

Á fornnorrænu máli eru til miklar bókmenntir sem fyrst og fremst eru verk Íslendinga - íslensku miðaldabókmenntirnar á móðurmálinu eru langtum fjölbreyttari og áhrifameiri en á öllum öðrum norrænu málunum samanlagt. Mestur hluti verkanna er varðveittur í handritum sem flest eru frá prettándu öld. 
Dönsk og sænsk mál voru pegar orđin nokkuð frábrugđin á tímaskeiđi fornnorrænu, pað er að segja að skipting í mállýskur innan norrænu málanna var pegar hafin. Pegar mátti sjá ađ danskan fór að greinast frá.

Frumnorræna er elsta formið af germansks máls sem til eru ápreifanlegar heimildir um í formi skriflegra minnisvarða. Frumnorræna hefur aðeins varðveist í áletrunum með sérstöku germönsku stafrófi sem nefnist rúnir. Flestar rúnir minna á latnesku bókstafina sem notađir eru í dag og pað bendir til að sá eđa peir sem bjuggu rúnirnar til pekktu eitt eða fleiri stafróf sem notuð voru í löndunum umhverfis Miðjarðarhafið. Elstu rúnaristur eru frá pví um 200 e. Kr. og fram undir 500 var frumnorræna töluð í allri Skandinavíu - og tiltölulega einslit. Frægasta rúnaáletrunin er á drykkjarhorni úr gulli sem fannst niðurgrafið árið
1734 við porpið Gallehus á SuðurJótlandi. Í pýđingu hljóðar textinn pannig: Ég Hlégestr frá Holti (e.t.v. sonur Holts ) gerði hornið.

Hve nærri petta mál liggur frumgermönsku má sjá með eftirfarandi samanburði par sem áletrunin á gullhornið er „pýdd“ yfir á allt frá endurgerðri frumgermönsku að nútímagermanska málinu gotnesku, sem er pekkt af biblíupýðingu, og yfir á hið verulega yngra norræna mál (*táknið framan við áletrunina merkir að ekki séu til neinar beinar heimildir um petta málstig).

FRUMGERMANSKA (u.p.b. 200 f. Kr.) *Ek Hlewagastiz hultijaz hurnan tawidōn

FRUMNORR/ENA (á 5. Öld)

Ek HlewagastiR holtijaR horna tawido

GOTNESKA (á 4. öld)

Ik Hliugasts hulteis haúrn tawida

NORR/ENA (frá u.p.b. 1000)

Ek Hlégæstr hyltir horn táda

\section{Erfðaorð, tökuorð og aðkomuorð}

Talið er að orð, sem „fylgja hljóðlögmálunum“, eins og sjá má í dæmunum far og fe, hafi verið til í málinu frá alda öðli og af peim sökum eru pau erfðaorð.

Öll orð, sem svara til orða sem byrja á $p$, hafa samt sem áður ekki breyst vegna germönsku hljóðfærslunnar. Í nútímagermönskum málum er til dæmis til fjöldi orða sem byrja á pater- eða patr- eins og t.d. paternalisme og patriark. Öll pessi orð hafa einnig eitthvað „föðurlegt" yfirbragð og pað er ekki af tilviljun. Detta eru svokölluð tökuorð eða aðkomuorð sem eru leidd af latneska (eða gríska) orðinu pater.

Á sama hátt er lýsingarorðið pekunicer leitt af latneska orðinu pecu. Í Róm hinni fornu var nefnilega pecu (húsdýr, nautgripir) eðlileg- 
ur verðmælir, samanber að lausafé merkti á fornnorrænu liggjanda fé en húsdýr ganganda fé.

pess vegna er ekki hægt að nota aðkomuorð til pess að sanna skyldleika mála. Pá væri út frá „norrænum“ orðum eins og sauna og sisu eða anorakk og kajakk hægt að draga pá ályktun að norræn mál væru skyld finnsku eða grænlensku en pví er ekki pannig farið. Aðkomuorð sýna aftur á móti að samskipti hafa farið fram á milli peirra sem töluðu útflutnings- og innflutningsmálin.

\section{Erfðaorð og aðkomuorð}

Erfðaorơ í málinu tilheyra gjarnan pví sem við teljum grunnorðaforða eins og töluorð (sbr. að ofan) og heiti á nánustu líffræðilegum ættingjum, sbr. faðir, móðir, systir og bróđir. Ef við lítum meira að segja til aðeins fjarskyldari ættingja finnum við oft aðkomuorð, sbr. onkel, tante, nevø og niese í skandinavískum málum, sem öll eru tekin úr frönsku, gagnstætt norrænum erfðaorðum (samsetningum) eins og föðurbróðirl móđurbróđir, farbror/morbror, fasterl moster (fars/mors søster) og systkinabarn, søskenbarn.

Aðkomuorð skiptast oft í svokölluð tökuorð og framandorð. аð sem miðað er við í pessari skiptingu er hversu „framandi“ orðið er. Ef orð er svo vel aðlagað málinu að aðeins málvísindamenn geta séð eða heyrt hvort orðið er upprunalega innflutt er pað oftast tökuorð. Petta á t.d. við um skandinavísk orð sem upprunalega koma frá germanska „,systurmálinu“ lágpýsku aðeins peir sem pekkja málsöguna vita að orð eins og prate, snakke og språk eru flutt inn úr lágbýsku en samheitin tale, tunge og mål eru norræn erfðaorð.
Ef við pekktum ekki málsöguna gæti pessu allt eins verið öfugt farið.

Sú staðreynd að lágpýsku orðin eru svo lítið framandi er sennilega hvoru tveggja um að kenna að pau hafa verið notuð í skandinavískum málum mjög lengi - flest frá pví um miðaldir - og að lágpýska er náskylt germanskt systurmál norrænu málanna. Af peim sökum purftu orðin ekki að taka miklum breytingum til pess að renna inn í málið svo lítið bar á - orđin prjú að ofan heita t.d. praten, snakken og sprake á lágpýsku.

Hins vegar hafa orð eins og konversere og lingvistikk framandi yfirbragd. Pau eru samsett úr páttum sem ekki er hægt að skilja umsvifalaust. Erfðaorð og tökuorð með fleiri en tveimur atkvæðum eru hins vegar oftast samsett úr skiljanlegum páttum, sbr. samtale og språk-viten-skap. Orð eins og konversere og lingvistikk kalla margir pess vegna framandord. Framandi yfirbragð orða er oft vegna pess að pau eru fengin að láni úr fjarskyldari málum - hin tvö síđastnefndu eru t.d. úr latínu. En framandleikinn getur líka verið vegna pess að orðin eru nýinnflutt. 
Ný orð, innflutt úr ensku eins og knowhow og goodwill, koma auðveldlega upp um sig bæði vegna pess hvernig pau eru skrifuð og fram borin. Hins vegar eru sennilega engir nema málvísindamenn sem vita að gamalt innflutt orð eins og kex á uppruna sinn í enska orðinu cakes - hér er aðlögun að íslenskri málgerð alger bæði hvað varðar stafsetningu og framburð. Kex telst pess vegna greinilega til tökuorða en ekki framandorða.

\section{Skandinavía: Mismunandi mál eđa bara mállýskur?}

Landfræðilegt svæði, par sem talmál breytist á pann hátt að nágrannar geta alltaf talað hver við annan á móðurmálinu og pannig að hvorugur purfi sérstaka pjálfun eða kennslu til pess að skilja hinn, er kallað mállýskusamfella. Hér á eftir má sjá hverju hægt er að hugsa sér að menn úr premur stórum skandinavískum borgum myndu svara væru peir spurðir hvar peir byggju. Hér myndí skilningur ekki valda vandamáli prátt fyrir að ekki sé um nágrannaborgir að ræða. Athugið að stafsetningin sýnir framburđinn en ekki hvernig stafsett er á hefðbundnu ritmáli.

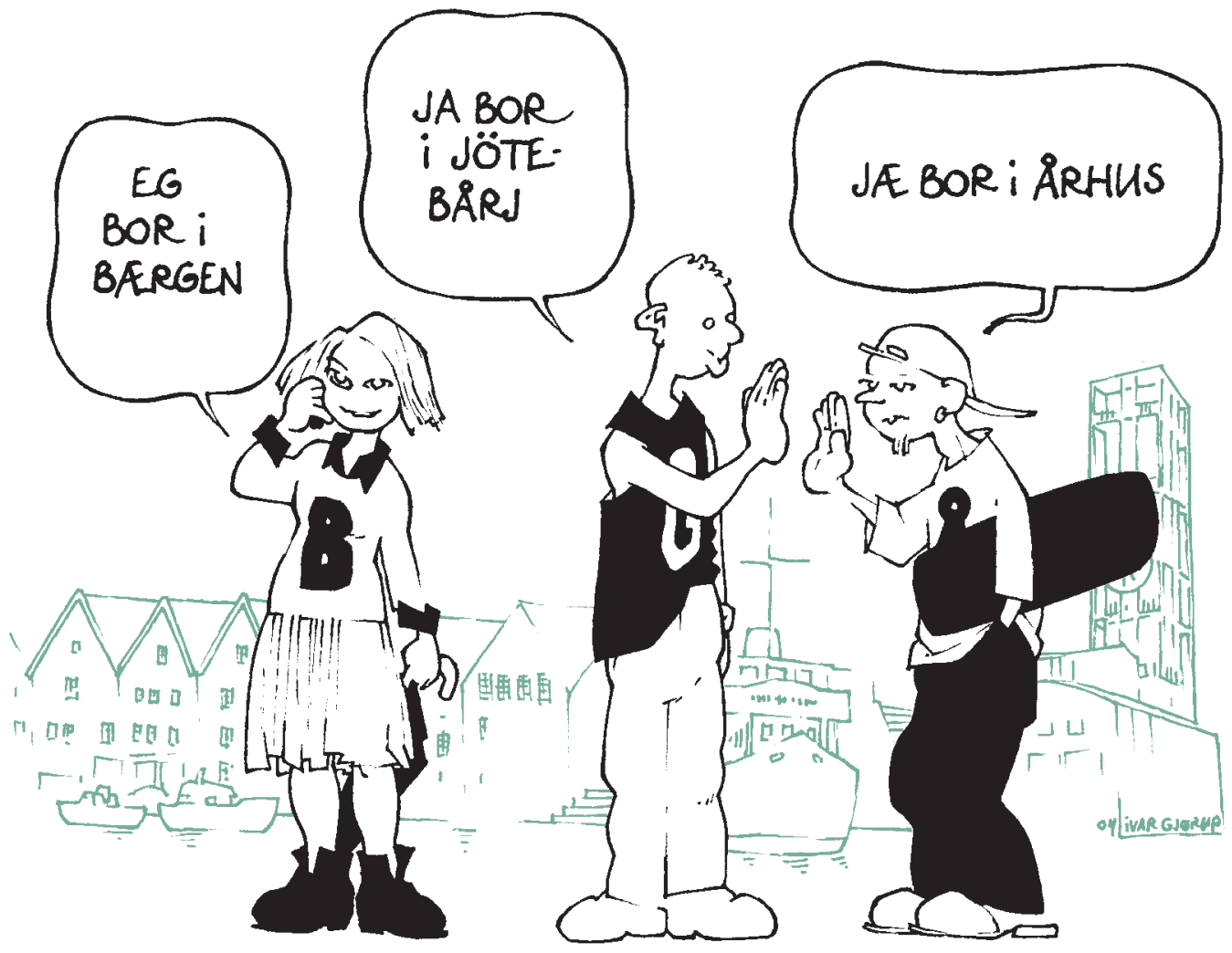


Svæðisbundnar mállýskur í Skandinavíu mynda pannig eina mállýskusamfellu. Ef ferðast er suður um Finnmörku í Noregi eftir Noregi, Svípjóð og Danmörku til Suður-Jótlands eða vestur frá Austurbotni í Finnlandi í gegnum Norður-Svípjóð að vesturströnd Noregs myndu nágrannamállýskur alltaf vera gagnkvæmt skiljanlegar.

\section{Fjarlægðarmál}

Ef t.d. bóndi úr Älvdalen í Svípjóð og sjómaður frá Vestur-Jótlandi í Danmörku ætluðu að tala saman hvor á sinni svæðisbundnu mállýsku myndu peir lenda í vandræðum. Vegna pess að älvdalsmál og vesturjóska eru augljóslega ekki gagnkvæmt skiljanleg, pau teljast til ólíkra fjarlaggđarmála. Drátt fyrir pað tilheyra pessi tvö talmál sömu mállýskusamfellu sökum pess að pað eru engin mikilvæg skil milli svæðisbundinna mállýskna milli Dalanna og VesturJótlands. Um er að ræða hægfara breytingu.

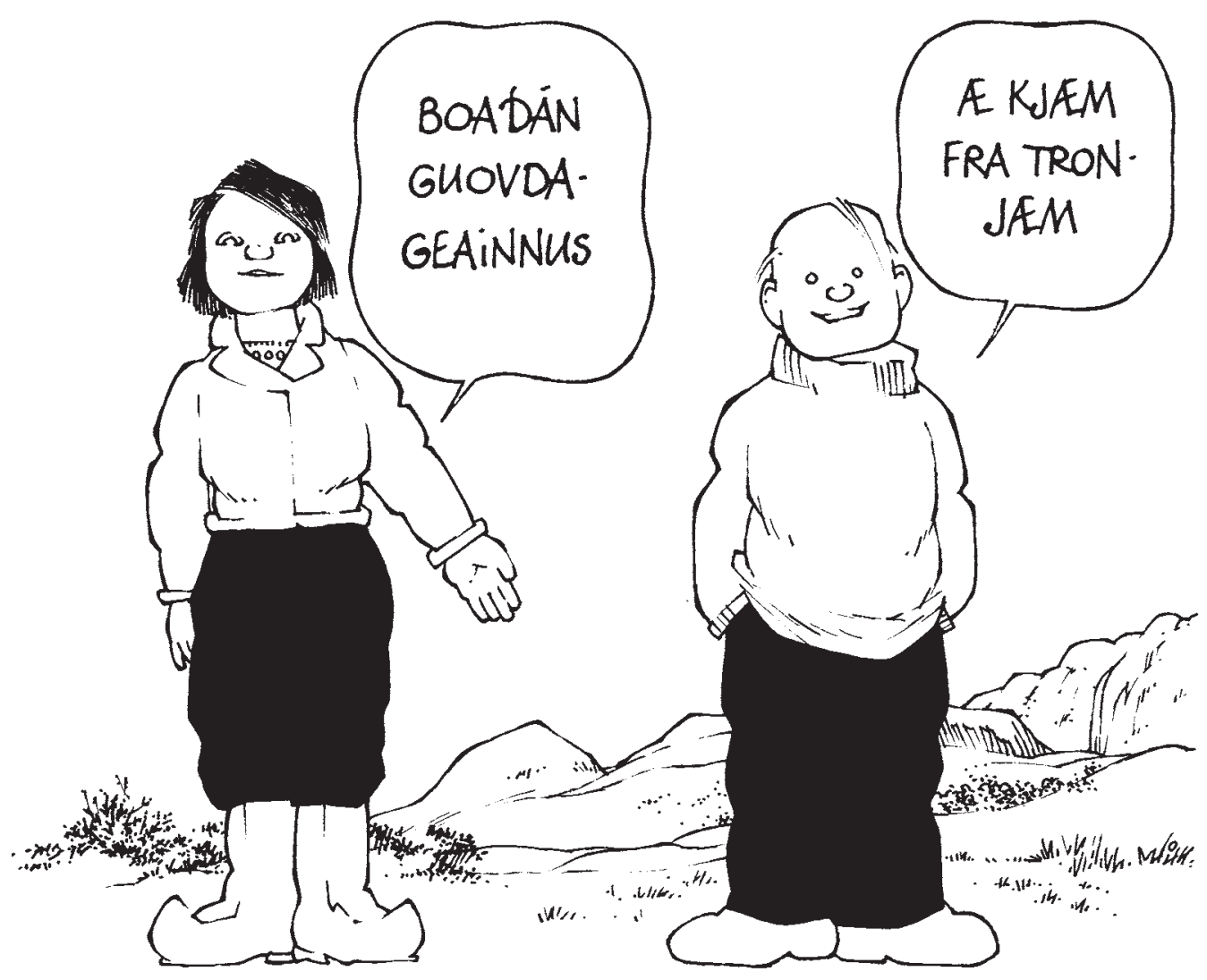




\section{Fjarlægðarmál}

Langi pig að heyra hvernig älvdalska og jóska hljóma geturðu fundið hljóðdæmi á pessum vefsvæðum:

swedia.ling.umu.se

www.statsbiblioteket.dk/dlh

Á landamærasvæðinu milli Svípjóðar og Noregs er pað næstum pví pólitísk ákvörðun að ákveða hvort telja á mállýsku til sænsku eða norsku - sums staðar hafa landamærin reyndar færst til síðustu hundrað árin - Jämtland og Härjedalen voru t.d. norsk svæði fyrir 1645. Hins vegar er mjög auðvelt að greina hvort Norðmaður talar samísku eða norsku eða hvort Finni talar finnsku eða sænsku. Í peim tilvikum er ekki um neina hægfara breytingu að ræða heldur er pað spurning um annaðhvort eða.

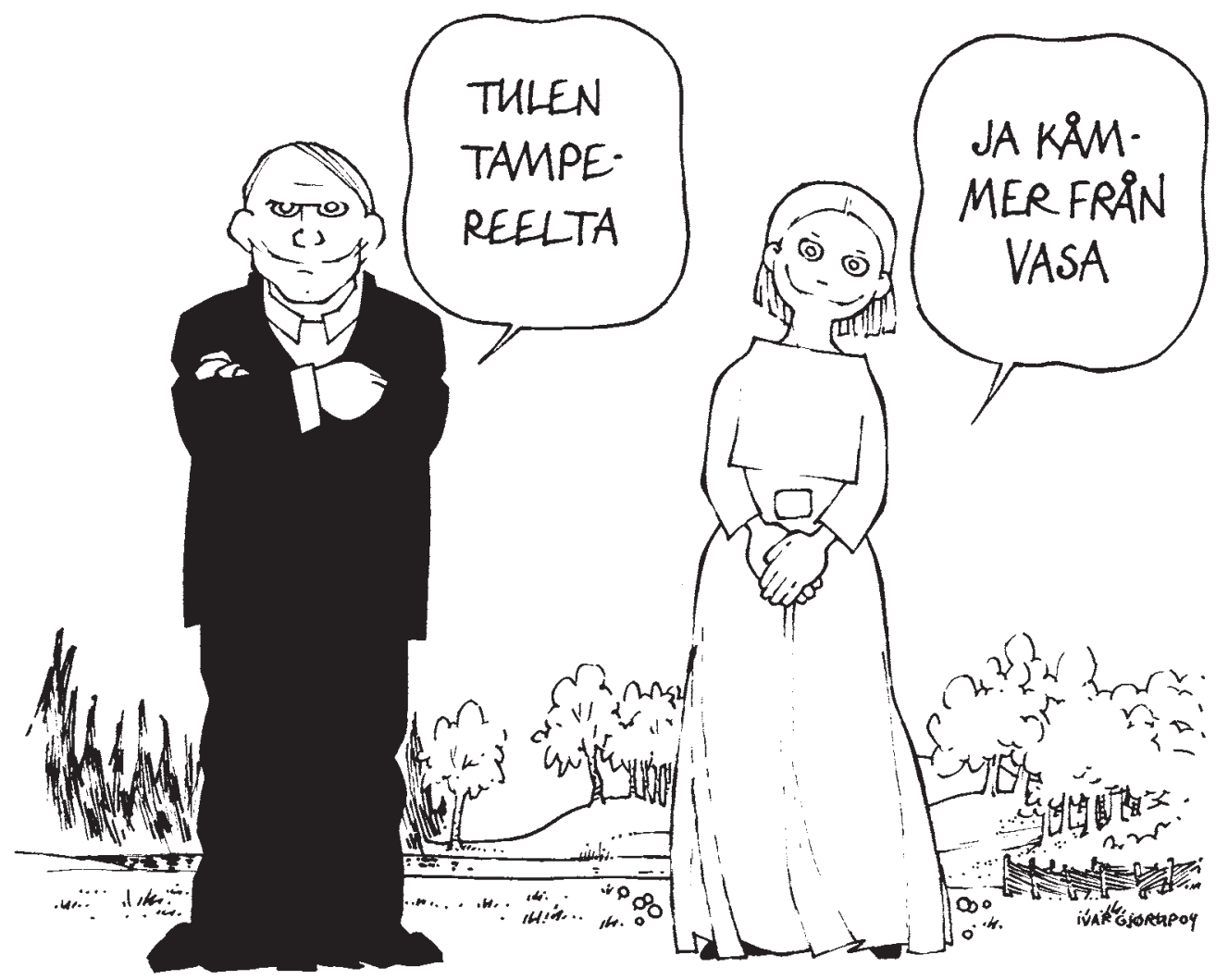


pað leikur heldur enginn vafi á pví hvaða mál er talað á landamærasvæði Dýskalands og Danmerkur pótt möguleikarnir geti verið margir og fjarlægð milli mála miklu minni. Hér mætast nefnilega prjár mismunandi germanskar mállýskur: suðurjóska, lágpýska (= niðurpýska) og norðurfrísneska. Dar að auki eru í dag margir sem tala bæði ríkisdönsku og hápýsku á landamærasvæðinu. Drátt fyrir að bilið á milli málanna sé langtum minna en á milli finnsku og sænsku eru ríkisdanska og hápýska ekki heldur milliliðalaust gagnkvæmt skiljanlegar. Í öllum pessum tilvikum er sem sagt um að ræða mismunandi fjarlægðarmál vegna pess að nágrannarnir skilja ekki mál hinna nema peir hafi lært pað.

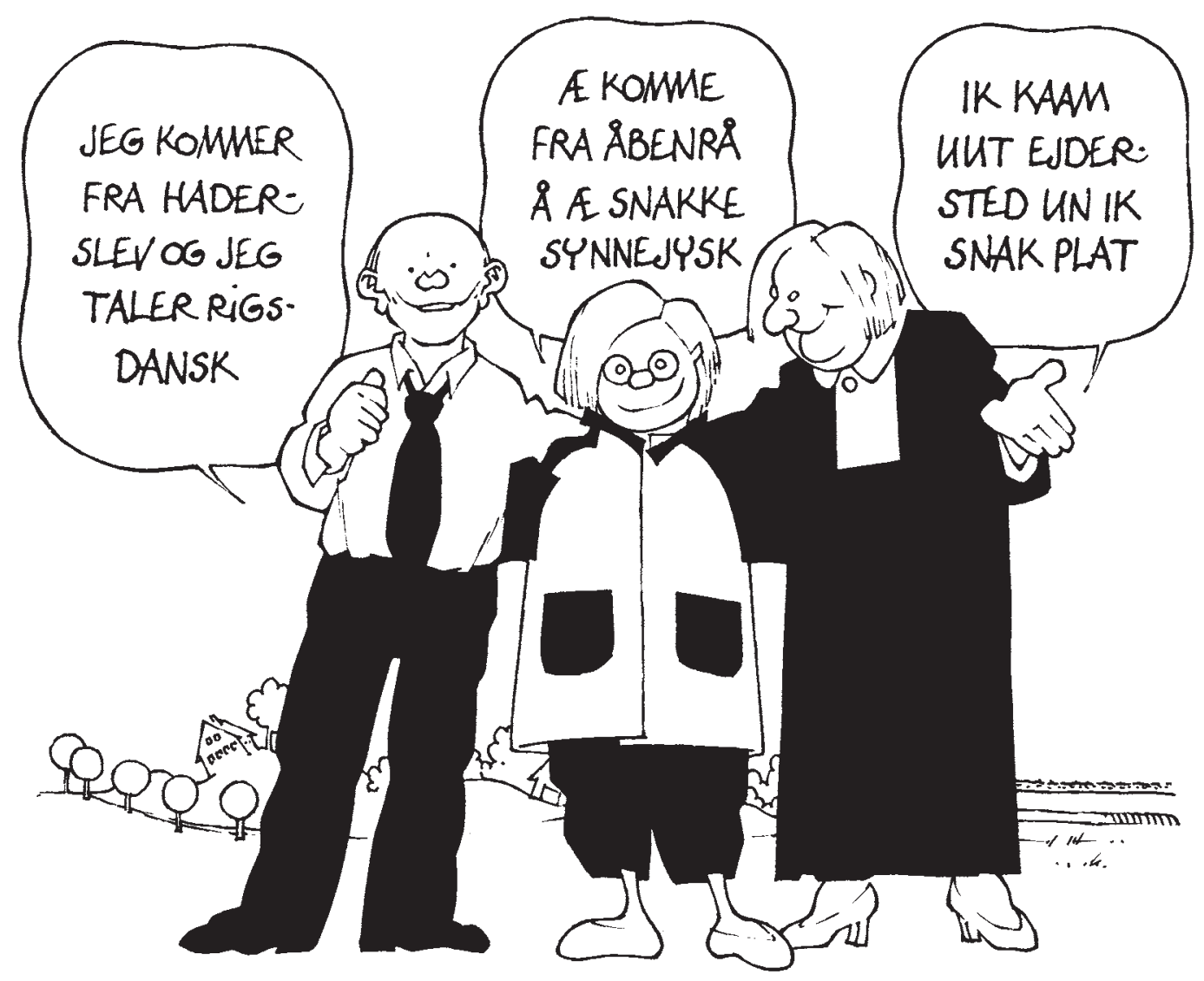




\section{Um suðurjósku, lágpýsku og norðurfrísnesku}

Ekki er til neitt viðurkennt staðlað ritmál fyrir pessar prjár mállýskur. Á heimasíðum, sem eru á slóđunum hér á eftir, má lesa meira um hverja málýsku og m.a. sjá að til eru margar ólíkar hugmyndir um hvernig á að lýsa

Lágbýska: $\quad$ www.lowlands-l.net www.rostra.dk/platt

Frísneska: www.lowlands-l.net

Suðurjóska: www.dialekt.dk www.jyskordbog.dk framburðinum. Sá sem talar frísnesku í dæminu hér á eftir er frá bæ sem á hápýsku heitir Niebüll (formið Naibel er svokallað „Algemeyn Nedersaksisch Schryvwyse“ p.e.a.s. almennur lágsaxneskur ritháttur).

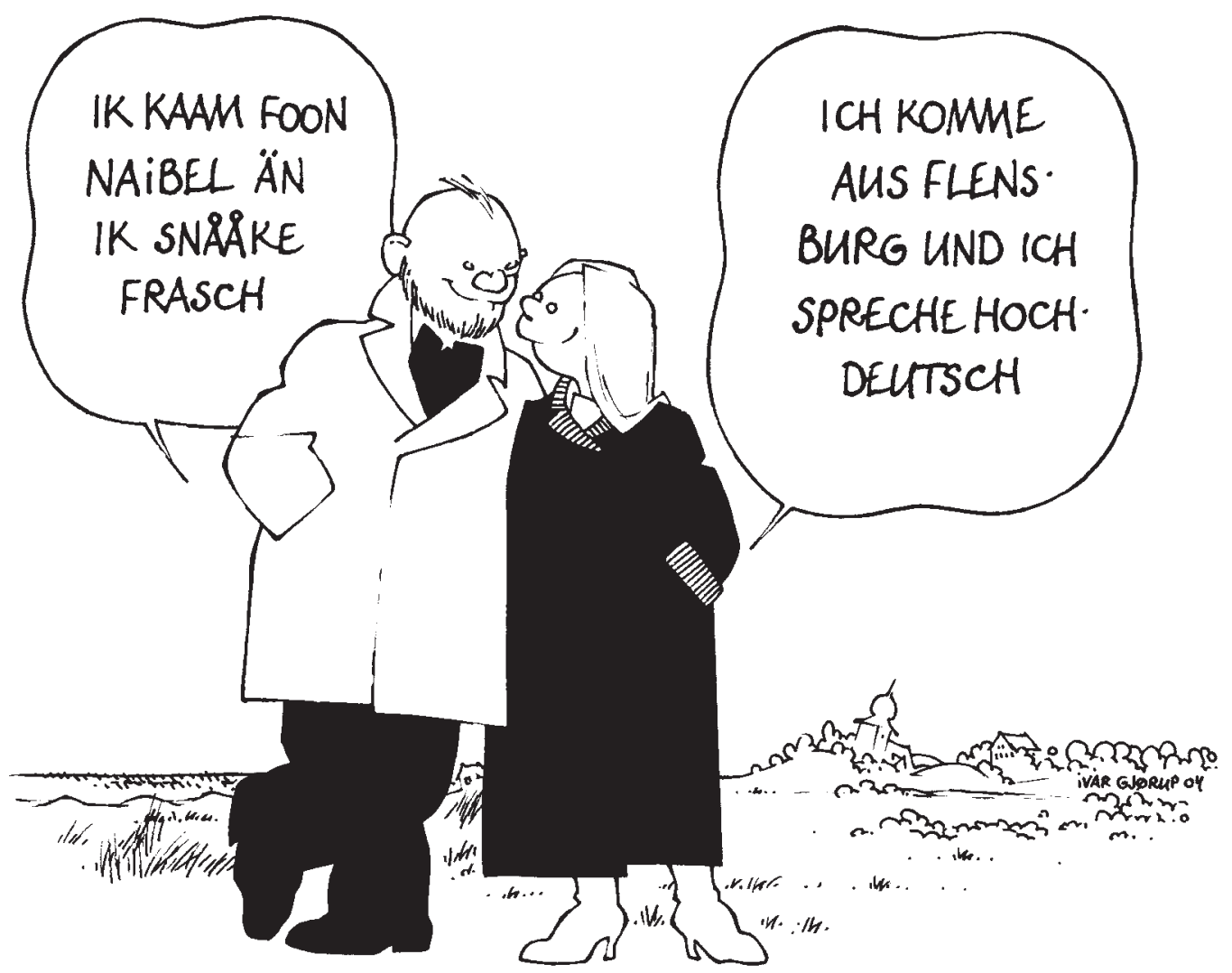




\section{Staðalmál}

Fram að pessu hefur verið rætt um skandinavísku mállýskusamfelluna eins og pað séu ekki til nein önnur talmál í Skandinavíu en svæðisbundnar mállýskur. Öllum er auðvitað ljóst að um pað er alls ekki að ræða - frekar hið gagnstæða. Í dag eru pað svokölluð staðaltalmál sem eru ríkjandi, að minnsta kosti í Danmörku og Svípjóð.

Staðaltalmál er talmál sem er staðlað, p.e. til eru reglur um hvernig talmálið eigi að vera. Staðaltalmál eru par að auki í samfélögum okkar mjög nátengd ritmáli. Bæði staðaltalmál og ritmál er tiltölulega samræmt á stærra svæði, t.d. innan pjóðríkis. Að pessu leyti skilur staðalmálið sig frá mállýskunum sem eru breytilegar eftir stöðum og eru oftast aðeins til sem talmál. Reglurnar um rétt málfar eru aðeins til í heila pess sem talar viðkomandi mállýsku.

Venjulega nýtur staðaltalmál mun meiri virðingar en staðbundnar mállýskur. Fyrir pessu eru aðallega félagslegar ástæður, meðal annars vegna pess að bæði staðaltalmálið og ritmálið grundvallast á talmáli peirra sem skara fram úr stjórnmálalega og efnahagslega, oftast í tengslum við höfuðborgina. En sökum pessarar félagslegu virðingar verður líka til hugmyndin um að staðalmálið sé eina „rétta“ málið og að mállýskurnar séu á einn eða annan hátt gallaðar. Degar rætt er um danskt og sænskt mál er pað að öllum líkindum staðalmál í riti og ræðu sem um er að ræða; danskar og sænskar mállýskur eru eiginlega eitthvað annað.

Í Danmörku og Svípjóð hnignar hefðbundnum mállýskum á flestum svæðum mjög mikið, pannig að pað er aðeins eldra fólk úti á landi sem talar „ekta mállýsku“ eins og málvísindamenn myndu kalla pað. Par að auki myndu allflestir Danir og Svíar næstum pví ósjálfrátt fela svæðisbundna mállýsku pegar peir tala við fólk úr öðrum landshlutum.

Í Noregi eru aðstæður aðrar. Ástæður pess eru meðal annars að í Noregi eru tvær útgáfur af ritmáli, svokallað bókmál og nýnorska, 
sem farið verður betur yfir síðar. En hinar sérstæðu aðstæður í Noregi varðandi málið endurspeglast einnig í peirri staðreynd að svæðisbundnar mállýskur eru meira notaðar í Noregi en í nágrannalöndunum. Formlega opinberast umburðarlyndið fyrir norskum mállýskum t.d. við pað að norskum kennurum er ekki heimilt að leiðrétta talmál nemendanna - nemendur hafa með öðrum orðum fullan rétt til að nota sitt eðlilega talmál í kennslustundum, óháð pví hvaða mállýsku er um að ræða. Og í rauninni kemur pað sama í ljós pegar staðbundnar mállýskur í Noregi eru notaðar við aðstæður par sem í nágrannalöndunum pykir sjálfsagt að nota staðaltalmál t.d. pegar pjóðkjörnir pingmenn gera athugasemdir á pjóðpinginu, Stortinget. Í talmiðlum eins og hljóðvarpi og sjónvarpi eru einnig oft talaðar mállýskur. Deir einu sem eru skyldaðir til pess að halda sig við bókmál eða nýnorsku eru starfsmenn norska ríkisútvarpsins NRK pegar peir nota handrit, en ekki í frjálslegum viðtalspáttum.

\section{Mállýskusamfella og staðalmál innan germanska málsvæðisins}

Ef við höldum okkur í Evrópu finnum við pessar mállýskusamfellur innan germanska málsvæðisins:

1. meginlandsgermanska: Austurríki, Sviss, Pýskaland, Norður-Belgía og stærstur hluti Hollands

2. frísneska: Hollenska héraðið Frísland

3. enska: Stærstur hluti Stóra-Bretlands

4. skandinavíska: Stærstur hluti Danmerkur, Svípjóđar og Noregs

5. færeyska: Færeyjar

6. íslenska: Ísland

Mynd 7: Germanskar mállýskusamfellur í Evrópu 

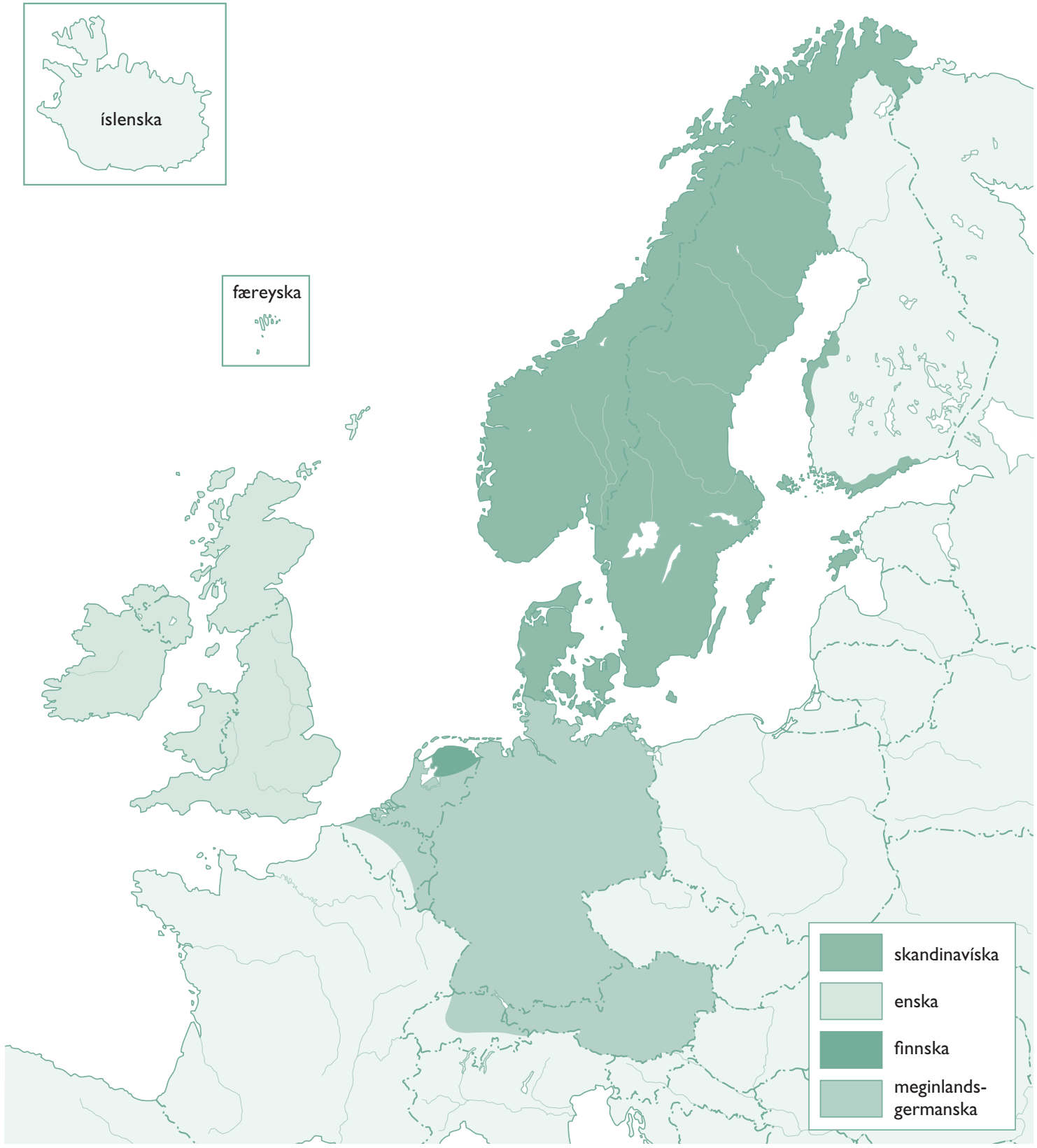

Mynd 8: Kort af germönskum mállýskusamfellum í Evrópu 
Innan hverrar mállýskusamfellu er að finna allt að fjögur mismunandi staðalmál. Á mynd 9 fyrir neðan kemur í ljós að aðeins meginlandsgermanska og skandinaviska eru til sem mállýskusamfella, ekki sem staðalmál. Innan beggja pessara heilda er að finna fleiri staðalmál á meðan pað er aðeins eitt staðalmál fyrir hvert hinna fjögurra (frísnesku, ensku, færeysku og íslensku).

1. meginlandsgermanska

a. pýska

b. hollenska

2. frísneska

3. enska

4. skandinavíska

a. sænska

b. danska

c. norska (bókmál og nýnorska)

5. færeyska

6. íslenska

Mynd 9: Germönsk staðalmál í Evrópu

\section{Prjú eđa fimm mál?}

Að puí er varðar skandinavísku er hægt að ræða hvort staðalmálin teljist prjú (danska, norska og sænska), fjögur (norska = bókmál og nýnorska) eða ef til vill fimm (sænska = Finnlands-sænska og Svípjóðarsænska).

Á málvísindalegum grundvelli er ekki ástæða til pess að telja sænskuna í Svípjóð öðruvísi en sænskuna í Finnlandi par sem ritmálið er eins, ritháttur, orðmyndun og beygingar eru sameiginlegar. Framburðurinn er áreiðanlega afar ólíkur en hann er einnig mismunandi innan Svípjóðar. Flestir Skandinavar geta auðveldlega heyrt mun á t.d. íbúum á Skáni og í Stokkhólmi pótt báðir tali sænskt ríkismál. Sænska verður sem sagt að teljast sem eitt mál, allavega eitt ritmál, prátt fyrir að pað sé notað í fleiri en einu landi.

Fyrir bókmál og nýnorsku gildir hið gagnstæða. Bæði málin eru aðeins notuð í Noregi en hér er aftur á móti um að ræða greinilegan mun. Lítum aðeins á pessar tvær setningar sem pýða nákvæmlega pað sama en öll orðin eru dálítið frábrugðin í útgáfunum tveimur:

- Jeg vet ikke hva de fortalte dere

(bókmál)

- Eg veit ikkje kva dei fortalde dykk

(nýnorska) 
prátt fyrir pennan greinilega mismun teljast bókmál og nýnorska engu að síður gjarnan sem eitt mál, „,norska“. Í Noregi eru bókmál og nýnorska hins vegar mismunandi málform af norsku par sem nýnorska og bókmál eru mismunandi út frá mörgum sjónarhornum. Málfarslega eru nýnorska og bókmál mismunandi prátt fyrir að bæði séu notuð í sama landi á meðan Finnlandssænska og „Svípjóðarsænska“ eru í raun alveg eins (að minnsta kosti hvað varðar ritmál) prátt fyrir að pær séu notaðar hvor í sínu landi.

\section{Hvers vegna bókmál og nýnorska?}

Ástæðurnar fyrir pví að til eru tvö norsk málform í Noregi, á sama tíma og hægt er að komast af með aðeins eitt form af bæði dönsku og sænsku, eru sögulegar og pólitískar. Bókmál er sögulega séð "norsk " útgáfa af danska ritmálinu sem var notað í Noregi frá peim tíma er landið var í stjórnmálasambandi við Danmörku (frá u.p.b. 1400 til 1814).

Nýnorska er aftur á móti nýtt ritmál sem var komið á um 1850 á grundvelli norskra mállýskna sem „pjóðernislegur“ valkostur á móti dönskunni. Maðurinn, sem bjó petta nýja ritmál til eftir að hafa ferðast vítt og breitt um Noreg og rannsakað „almúgamálið“, eins og pað var gjarnan kallað á peim tíma, var snillingurinn og sjálflærði málvísindamaðurinn Ivar Aasen (1813-1896). Bókmál er pess vegna afar líkt dönsku - í ritmáli en ekki í framburði! En nýnorskan á ýmislegt sameiginlegt með færeysku og íslensku. Á Færeyjum og Íslandi settist nefnilega að fólk - fyrir um pað bil púsund árum - sem flest allt var frá Vestur-Noregi, og nýnorskan líkist pess vegna einna helst mállýskunum í Vestur-Noregi. Í pessum hluta landsins er nýnorska aðalritmálið í skólum en annars staðar í Noregi er bókmál aðalmálið.

\section{Norræn nútímamál}

Ef staðalmálin, sem falla undir norrænu, eru talin fáum við samtals fimm eða sex mál: fimm, ef „norska“ telst sem eitt mál, og sex ef norsku málformin (bókmál og nýnorska) hvort um sig eru talin sérstakt mál. Teljum við aftur á móti norsku sem eitt mál og notum gagnkvæman skilning sem grundvöll fyrir skiptingu í mál væri eðlilegt að flokka norræn nútímamál á eftirfarandi hátt: 


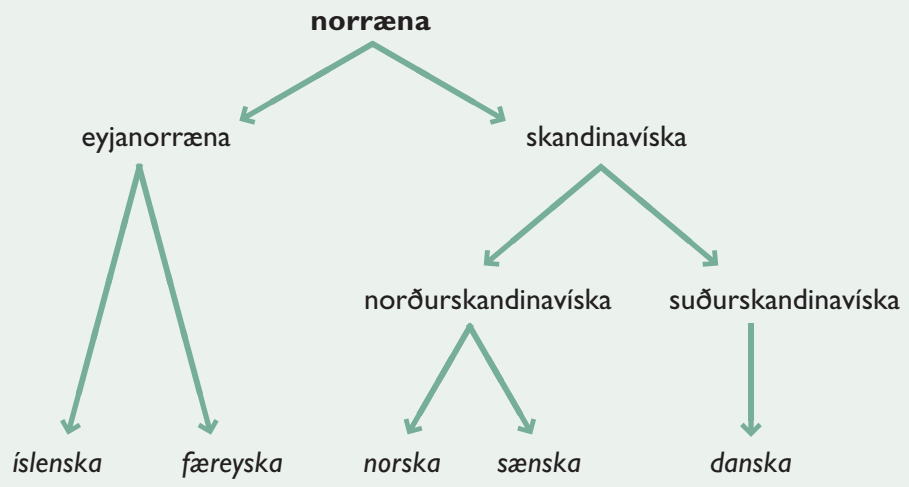

Mynd 10: Skipting norrænna mála í dag á grundvelli gagnkvæms skilnings

Detta tré sýnir að skilin á milli skandinavísku annars vegar og eyjanorrænu hins vegar eru mikilvægustu skilin í dag. Eyjanorræna og skandinavíska eru að mestu leyti gagnkvæmt vandskilin, bæði í mæltu máli og rituðu. Ritmál íslensku og færeysku eða eyjanorrænu má ef til vill telja gagnkvæmt skiljanleg en varla talmálið pótt Færeyingar skilji íslensku betur en Íslendingar færeysku. Andstætt pessu eru skandinavísku málin sem segja má að séu næstum pví gagnkvæmt skiljanleg, bæði í rituðu máli og töluðu.

Enn fremur sýnir myndin að mismunurinn á dönsku (= suðurskandinavísku) annars vegar og norsku eða sænsku (= norðurskandinavísku) hins vegar er meiri en munurinn á norsku og sænsku. Mikilvægt er að vera meðvitaður um að myndin sýnir fyrst og fremst hvernig staða talmálsins er í dag par sem pað er fyrst og fremst framburður dönskunnar sem er frábrugðinn og myndar pessi skil. Sé farið eftir ritmálinu líkist norska bókmálið dönsku miklu meira en sænsku. Norskur framburður hefur hins vegar alltaf verið líkari sænsku en dönsku.

Með mikilli einföldun getum við pví sagt að Norðmenn og Svíar eigi, vegna landfræðilegrar legu (nánir nágrannar í Skandinavíu), meira sameiginlegt í framburđi. Af sögulegum ástæðum (stjórnmálasambandi og sameiginlegu ritmáli í yfir fjögur hundruð ár) eigi Norðmenn aftur á móti stærsta hluta orðaforðans og ritháttinn sameiginlegan Dönum. 


\section{Ættartréð endurtekið}

Eins og áður hefur komið fram lítur ættartréð, p.e.a.s. skipting norrænna mála eftir sameiginlegum uppruna (mynd 5), allt öðruvísi út en tréð sem kynnt var í síðasta kafla (mynd 10) par sem skiptingin er eftir gagnkvæmum skilningi milli nútímamálanna. Hér er pað endurtekið:

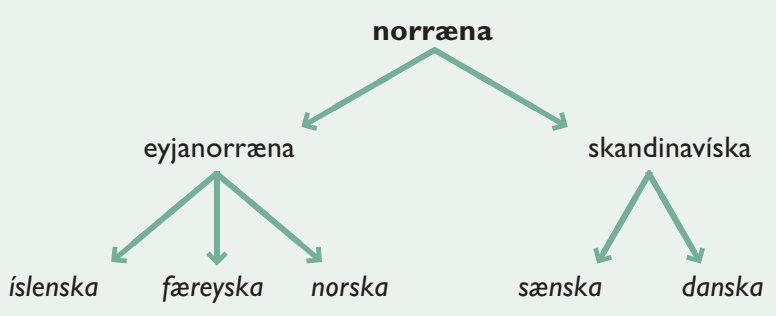

Mynd 5 (endurtekin): Skipting norrænna mála á ættartrénu

Lengi hefur verið ljóst að ættartré sýna ekki alltaf jafn „sennilegar“ niðurstöður - pannig að andstaða getur orðið milli pess hvernig menn skynja mismunandi tungumál og hvernig skyldleika peirra er háttað - sögulega séð. Degar í lok nítjándu aldar kom Djóðverjinn Johannes Schmidt (1843-1901) fram með hina svokölluðu bylgjukenningu. Hann notaði líkingu við bylgjur sem breiðast út eins og hringir á vatnsfleti eftir að steinvölu hefur verið kastað út í.

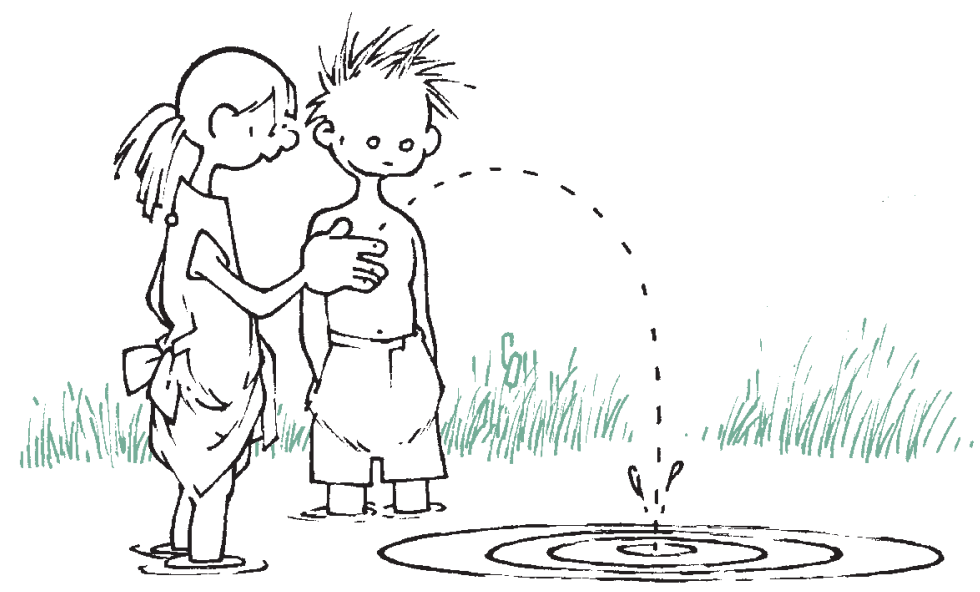


Bylgjukenningin er táknræn fyrir breytingu á máli - nýsköpun sem breiðist yfir málsamfélag. Degar mismunandi steinar lenda á ólíkum stöðum í vatninu munu öldurnar smám saman mynda flókið mynstur hringja sem skarast á ýmsan hátt.

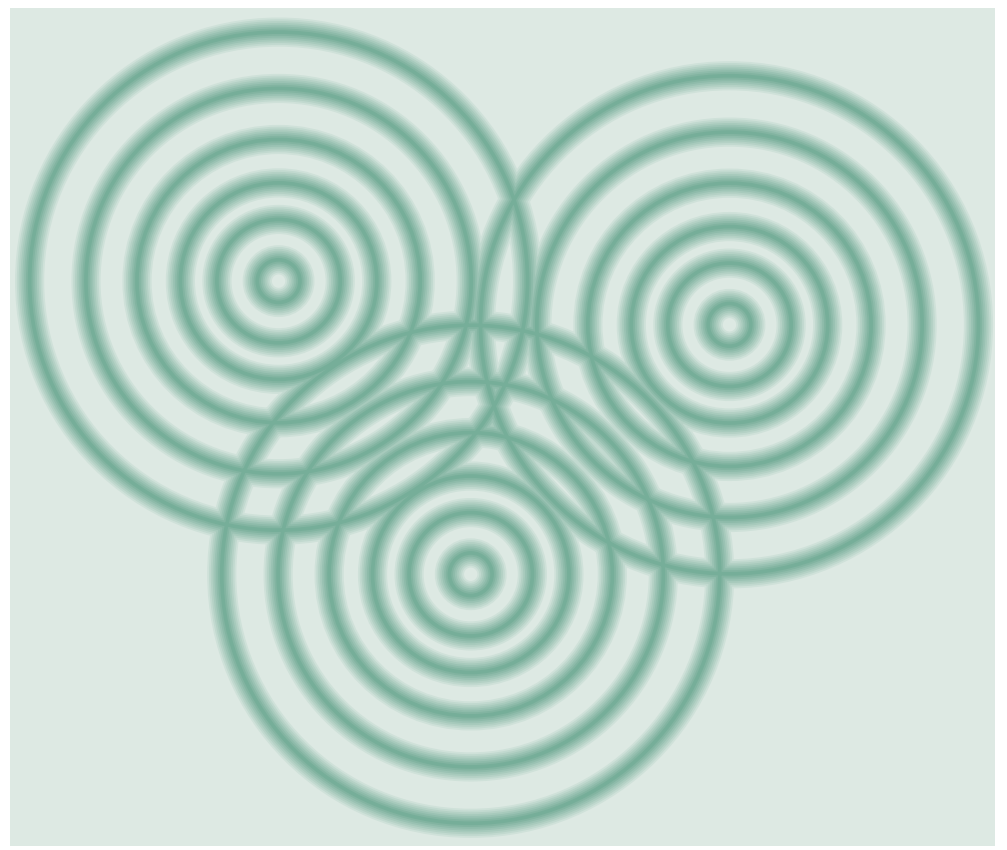

Mynd 11: Yfirlit yfir bylgjukenninguna

Bylgjukenningin veitir raunhæfari mynd af pví hvernig málbreytingar breiðast út par sem mörk mállýskna eru ekki stöðug en geta pvert á móti verið ólík á mismunandi tímabilum. Petta er ekki heldur merkilegt. Mállýskukort sýnir greinilega samskiptamunstur á ákveðnu svæði. Fólk, sem á náin samskipti, talar pannig frekar líkt mál en fólk, sem hittist sjaldan eða aldrei, mun tala ólíkt mál eftir nokkrar kynslóðir. Ef samskiptamynstur breytast með tímanum, til dæmis af efnahagslegu eða stjórnmálalegu umróti, mun mállýskukort smám saman bera vitni um pað á pann hátt að gömul mörk færast til eða ný mörk verða til. 


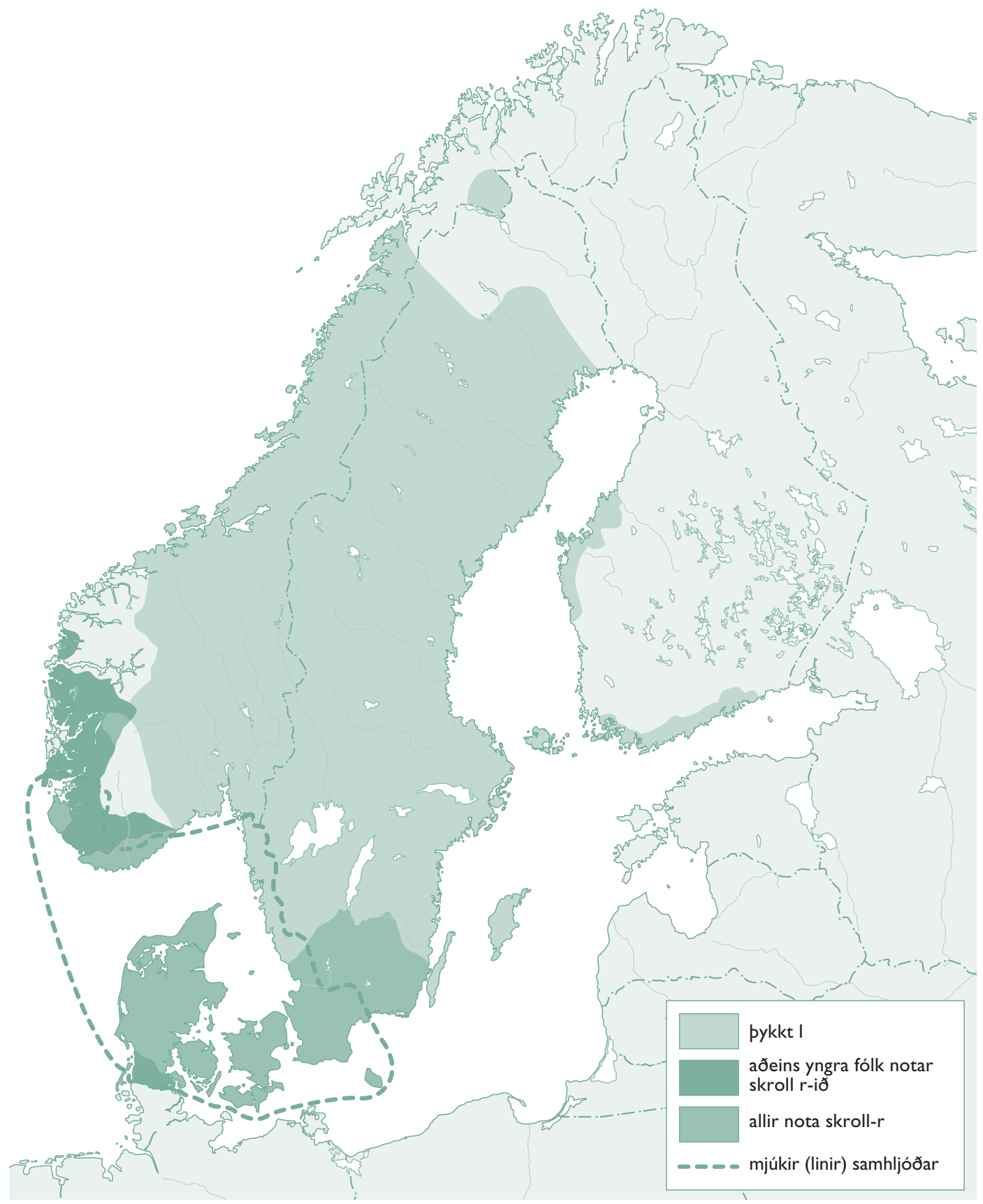

Mynd 12: Prenns konar mismunandi framburður á skandinavísku sýndur með bylgjukenningunni 


\section{Pykkt I}

Dykkt $l$ vísar til pess $l$-hljóðs sem menn í austurhluta Noregs og norðurhluta Svípjóðar bera fram í orðum eins og dal (dalur) og sol (sól) og einnig oft í stað rd í orðum eins og bord (borð) og jord (jörð).

petta hljóð eiga peir sem ekki hafa alist upp við pað afar erfitt með mynda pótt peir reyni og pannig hefur pað sennilega alltaf verið. Sænski málvísindamaðurinn Samuel Columbus hélt pví fram í kringum 1680 að til væri „ett tiockt ell i Swenskan“, p.e. „pykkt $l i ́$ sænsku“, sem ókunnir gætu ekki borið fram.

Í málvísindum er petta hljóð táknað sem svo kallað skellihljód, p.e.a.s. að tungan er beygð aftur á bak og henni sleppt fram pannig að hún slæst við góminn í efri kjálka. Einfalt fyrir pá sem hafa æft sig frá blautu barnsbeini en frekar erfitt fyrir pá sem reyna í fyrsta skipti eftir að hafa náð fullorðinsaldri.

bykkt $l$ er reyndar frekar framandi fyrirbæri í Evrópu par sem pað er aðeins til sums staðar á norsku og sænsku (að Finnlandssænsku meðtalinni) málsvæði. Á Indlandi er hljóðið aftur á móti til í mörgum málum svo að á heimsmælikvarða telst pað varla merkilegt.

\section{Mjúkir samhljóđar}

Með mjúkum samhljóðum er átt við að orð eins og bryte (brjóta), krype (skriða) og ryke (reykja) eru borin fram eins og bryde, krybe, ryge - pannig að $p, t, k$ inni í og í enda orðs verður að $b, d, g$. Detta er breyting á framburði sem hófst í Danmörku. Í fornri dönsku voru nefnilega líka $p, t, k$, eins og enn pá er algengast í sænsku og norsku. En í Danmörku hefur pessi mýking gengið ennpá lengra en í suðursænsku og suðvesturnorsku mállýskunum sem hún kemur fyrir í. Í mörgum dönskum mállýskum eru pessir samhljóðar reyndar alveg horfnir (brye/ bryđ, kryw, ryy) og í ríkisdönsku hefur próunin komin miklu lengra en nokkurs staðar í sænsku eða norsku. Detta er pví án efa sú hljóðbreyting sem gerir pað að verkum að Svíum og Norðmönnum finnst Danir tala ógreinilega.

\section{Skroll-r}

Skroll-r er $r$-ið sem er notað m.a. í dönsku og suðursænsku, gagnstætt tungubrodds- $r$-i sem flestir Svíar og Norðmenn nota. Mismunurinn á pessum $r$-gerðum liggur í pví hvaða hluti tungunnar er virkastur. Eins og nafnið bendir til er tungubrodds-r myndað með 
pví að tungubroddurinn eða fremri hluti tungunnar slæst eða titrar við efri góminn en skroll $r$-ið er borið fram með pví að aftari hluti tungunnar er hvelfdur að mjúka gómnum, p.e.a.s. aftasta hluta munnsins, pannig að pað verður titringur eða núningur á milli tungunnar og gómsins eða úfsins.

Af pessum premur ólíku páttum eru bæði pykkt $l$ og mjúkir samhljóðar táknræn fyrir gömul fyrirbrigði sem hafa hugsanlega komið fram fyrir meira en púsund árum. Dykka l-ið hefur sennilega komið fram einhvers staðar miðsvæðis í Skandinavíu en vagga mjúku samhljóðanna hefur, eins og komið hefur fram, verið í Danmörku. Dykka l-ið hefur síðan aðeins breiðst út vegna samskipta mállýskna á landi. Útbreiðsla mjúku samhljóðanna á sænsku og norsku svæðunum sýnir hins vegar að samskiptin hafa verið sjóleiðis. Mörkin fyrir bæði pykkt $l$ og mjúka samhljóða hafa pegar verið orðin stöðug fyrir mörg hundruð árum.

Skroll-r-ið er án efa nýrra fyrirbæri. Á fyrri hluta átjándu aldar skrolluðu afar fáir og pá helst einstaklingar með málgalla. En á næstu tveimur öldum breiddist skroll-r-ið út yfir allt svæðið sem sýnt er á kortinu á mynd 12 og í Vestur-Noregi er útbreiðsla pess enn að aukast. Vagga skroll-r-sins í Evrópu stóð sennilega í París í lok sautjándu aldar. Í Skandinavíu kom pað líklega fyrst fram í Kaupmannahöfn og paðan „stökk“ pað til stærri borga eins og Málmeyjar, Björgvinjar, Stavangurs og Kristiansands.

\section{Frumlegar og minna frumlegar útskýringar á uppruna skroll-r-sins}

Til eru margar skemmtilegar kenningar um skroll-r-ið en pví miður eru pær líklega ekki réttar. Eftir einni vinsælli útskýringu á skroll r-ið að hafa komið frá frönskum konungi með málgalla, hann skrollaði. Hirð hans hermdi eftir honum til pess að smjaðra fyrir honum. pað sem er ólíklegt við pessa kenningu er að einstakur málgalli hafi verðið svo smitandi, jafnvel pótt uppruni smitberans hafi verið konunglegur. Ef öllum var par að auki ljóst - að meðtöldum einstaklingnum sjálfum - að um málgalla var að ræða hefði viss áhætta fylgt pví að herma eftir honum. Eftirhermurnar gætu allt eins hafa verkað sem skopstæling en ekki málfarsleg „,samstaða“.

Danski málvísindamaðurinn Otto Jespersen gefur allt aðra skýringu. Hann færir rök fyrir pví að breytingin hafi orðið vegna pess að úti á landi hafi menn haldið sig að mestu utan dyra og 
par hafi málhljóđin auðveldlega drukknað í pyti vindsins og nið̋i fossa og pá hafi menn orðið að nota kröftug tungubrodds-r til pess að heyra hver í öðrum. En í borgum hafi menn aðallega verið innan dyra og pví hafi peir ekki haft jafnríka pörf fyrir hörð hljóð:

[L]ifið innan dyra hefur i för með sér hægara tal og menn brýna ekki jafnmikið raustina að hluta til vegna pess að pað er óparfi og að hluta til vegna pess að pað gæti sýnt óvarkárni (veggirnir hafa eyru). Pví tignara sem heimilislifið er (með teppum á gólfum og verði við dyrnar) pví dempaðra verður einnig málið (íslensk pýðing úr dönsku).
Réttu skýringuna á upprunanum er líklega að finna í ákveđinni eðlilegri málfarspróun á parísarfrönsku á sautjándu öld og í pví hvorki neitt sameiginlegt með málgalla né borgarlífsstíl. Hröð útbreiðsla til hluta af Vestur-Evrópu, fyrst til borga, getur aftur á móti að hluta til stafað af pví að skroll-r-ið er í rauninni auðveldara í framburði en tungubrodds-r-ið. Pegar skroll-r-ið var orðið til sem viðurkenndur framburður eftir að hafa aðlagast hinni virðulegu parísarfrönsku pá var leið pess greið og pað fór sigurför um mestan hluta Vestur- og NorðurEvrópu.

Bylgjukenningin sýnir greinilega hvernig breytingar geta orðið til á mismunandi stöðum innan mállýskusvæðis og hvernig samskiptamynstrið getur haft áhrif á útbreiðslu fyrirbæra í framtíðinni.

Ættartréð sýnir hins vegar að skipting á ákveðnum tímapunkti hefur áhrif á allar síðari skiptingar - greinarnar á trénu geta nefnilega ekki vaxið aftur saman seinna, pær nálgast ekki einu sinni hver aðra. bað er pessi grundvallarmunur sem gerir ættartréð óhæft ef nota á pað til pess að endurspegla hvað er raunverulega líkt og ólíkt með norrænum nútímamálum. Hvernig líkönin tvö geta bætt hvort annað upp mun verða fjallað um síðar. 


\section{Söguleg skipting norrænna mála með bylgjukenningunni}

\section{Frá frumnorrænu fram á víkingaöld}

Um 700 var svokölluð frumnorrcena töluð í Skandinavíu. Hafi verið til mismunandi mállýskur pá hefur mismunur á milli peirra verið lítill. Ekki eru dæmi um nein mállýskumörk sem hægt er af öryggi að rekja aftur til pess tíma.

Frumnorræna sker sig greinilega frá öllum síðari stigum norrænna mála. Sé próun mannanafna t.d. skoðuð er greinilegt að miklar breytingar hafa orðið næstu 300-400 árin par á eftir. Löng, viðhafnarmikil nöfn eins og AnulaibaR og HarjawaldaR hljóma pegar um árið 1000 eins og Óláfr og Haraldr og eru aftur á móti ekki svo ólík nútímanöfnunum í norsku og dönsku: Olav og Harald, sænsku: Olov/Harald, færeysku: Ólavur/Haraldur og íslensku: Ólafur/Haraldur.

pegar á peim tíma verður að reikna með að málfarslega fjarlægðin frá frumnorrænu hafi verið orðin svo mikil að málin hafi ekki verið gagnkvæmt skiljanleg. Ef hið ósennilega hefði gerst að norrænn maður frá sjöttu öld hefði komið fram á meðal víkinganna 4-500 árum seinna hefðu peir að öllum líkindum alls ekki skilið hver annan. Hins vegar gæetum við í dag sennilega talað án mikillar fyrirhafnar við fólk sem var uppi á sextándu öld svo framarlega sem við héldum okkur við efni sem báðir aðilar hefðu forsendur til að hafa einhverja skoðun á. Breytingarnar, sem urðu á málunum á milli 500 og 1000, voru með öðrum orðum miklu meiri en á milli 1500 og 2000.

\section{Rúnir}

Heimildir um pekkingu á frumnorræna málinu eru ristur í bein, málm og stein ritaðar með sérstökum táknum sem eru kallaðar rúnir. Frægust allra frumnorrænna rúnaristna fannst á gullhorni á Jótlandi í Danmörku á átjándu öld. Hún útleggst pannig: ek HlewagastiR holtijaR horna tawido, p.e.: Ég Hlégestur frá Holti (etv. sonur Holts) gerđi hornið.

Elstu rúnaristurnar eru frá pví um 200. Hinar svo kölluðu eldri rúnir eða fupark, eins og pær eru einnig kallaðar eftir hljóðgildum fyrstu sex táknanna, líta pannig út: 


\section{FAPFR<XP HHLEAY TBMATODX}

\section{fuparkg w h $\mathrm{n}$ i j pë Rs t b e m I $n$ d o}

Mynd 13: Eldri rúnaröðin

Eins og sjá má eru táknin samtals 24 og samsvöruðu pau sennilega nokkurn veginn nákvæmlega frumnorræna hljóðkerfinu. Um hljóðgildi nokkurra rúna er ekki vitað með neinni vissu en eins og sjá má eru flest táknin nokkuð lík samsvarandi latneskum bókstöfum sem notaðir eru í dag. Í peim tilvikum getum við með nokkurri vissu verið örugg um að framburðurinn er eins og sá sem við pekkjum úr öðrum málum sem nota petta stafróf. pessi samsvörun sýnir að sá eða peir sem bjuggu rúnirnar til pekktu að minnsta kosti eitt stafrófanna sem notuð voru í löndunum umhverfis Miðjarðarhafið. Sjálft form táknanna - bein strik sem standa lóðrétt eða hallandi bendir hins vegar til að pau hafi upphaflega verið ætluð til pess að skera í tré með hníf - í pess konar efnivið og með pannig verkfærum er frekar óhentugt að nota tákn með bogum og láréttum strikum. Frá tímum frumnorrænu hafa ekki varðveist neinar rúnaristur í tré sennilega vegna pess að tré er forgengilegt efni. Allar varðveittar áletranir eru pess vegna ristar í stein, málm eða bein.

Um 700 var eldri rúnaröðin einfölduð á pann hátt að táknum var fækkað úr 24 í 16. Pversögnin er að um svipað leyti fjölgar hljóðum í málinu pannig að eiginlega hefði átt að vera pörf fyrir fleiri tákn en ekki færri en áður ef hvert hljóð átti að eiga sitt tákn. Hvers vegna petta gerist er ekki vitað en hlýtur að tengjast peim miklu breytingum sem verða á tungumálum á sama tímabili. Ef til vill var hugsunin sú að fyrst 24 tákn væru ekki nægilega mörg til pess að koma til 
skila öllum hljóðum málsins lengur pá væri pað ekki svo hættulegt pótt hvert hljóð ætti sér ekki eigið tákn. Samhengið sýndi hvort sem er oftast hvað um væri að ræða.

Rúnirnar hurfu að minnsta kosti ekki vegna pess að táknunum fækkaði og vegna pess að rúnaröðin frá pví á elleftu öld pyrfti að keppa við latneska stafrófið - pvert á móti voru pær notaðar í mörg hundruð ár eftir að farið var að nota latneska stafrófið. Ástæðurnar voru áreiðanlega pær að á margan hátt var einfaldara að nota rúnirnar - ekki aðeins að pað pyrfti að nota færri tákn heldur var fyrst og fremst umað ræða einfaldari tækni við ritun - hnífur og spýta var nóg ef pörf var á að krota stutt skilaboð en latneskir bókstafir kröfðust fjaðurpenna, bleks og kálfskinns.

pegar rúnirnar loksins hopuðu fyrir latneska stafrófinu pegar liðið var á fimmtándu öldina höfðu pær verið notaðar næstum pví samfellt í 1500 ár á Norðurlöndum. Sem sagt næstum pví helmingi lengur en stafrófið sem notað er í dag!

\section{$F \cap P+R Y *+1 \nmid h \uparrow B \Psi \wedge \lambda$

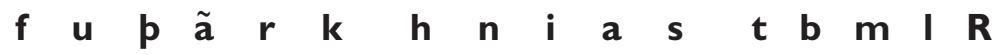
Mynd 14: Yngri rúnaröđin

\section{Austurnorræna og vesturnorræna}

Elstu ólíku mállýskurnar, sem pekktar eru innan norrænna mála, verða til við upphaf aðgreiningar á austur- og vesturnorrænu svæði á áttundu og níundu öld. Ennpá var um eina mállýskusamfellu að ræða: Allir, sem töluðu norræn mál, bjuggu nefnilega ennpá í Skandinavíu eða höfðu flust paðan nýlega til eyjanna vestar í Atlantshafi eða til Bretlandseyja, Normandí, Rússlands o.s.frv. 
Petta er ástæða pess að norræn mál eru oft kölluð skandinavísk mál; fyrir útpensluna miklu á tímum víkinganna voru pessi mál aðeins töluð í Skandinavíu.

Mismunurinn á mállýskum á pessum tíma var líka hverfandi. Bæði peir sem bjuggu í Skandinavíu og aðrir skynjuðu norrænu sem eitt mál sem oftast var nefnd dönsk tunga, p.e.a.s. danskt tungumál. Hvers vegna pað voru einmitt Danir sem fengu heiðurinn af pví að halda uppi merki allrar Skandinavíu málfarslega er ekki alveg ljóst en merkingin hefur hugsanlega orðið til í Englandi par sem Danir voru alls ráðandi á tímum víkinganna. Eftir pað hefur heitið dönsk tunga verið yfirfært á öll norræn mál prátt fyrir að ekki hafi verið um að ræða „dönsku“ í pröngum skilningi orðsins. En fyrir alla utanaðkomandi hlaut pað að virðast vera sama málið.

Eftir 700 kemur smám saman fram ákveðinn munur eftir mynstri sem gerir pað að verkum að eðlilegt er að tala um vestur- og austurgrein norrænna mála.

\begin{tabular}{c|r} 
vesturnorræn mál & austurnorræn mál \\
islenska, færeyska, norska & sænska, danska
\end{tabular}

Mynd 15 a: Skipting norrænna mála u.p.b. 700-1200

Vesturnorrcen mál munu á pessum tíma í grófum dráttum hafa verið norska - eftir landnámið á Færeyjum og Íslandi (p.e.a.s. frá lokum níundu aldar) - að meðtalinni færeysku og íslensku. Đað var aðallega fólk frá Noregi, sérstaklega Vestur-Noregi, sem settist að á pessum eyjum og pað einkennir málin par enn í dag.

Austurnorrcen mál eru pá pau mál sem eftir eru á norræna svæðinu, sem sagt danska og sænska.

Ýmsan mun á norrænum nútímamálum má rekja aftur til pessa tíma, p.e.a.s. elsta mállýskuklofningsins í vestur- og austurnorræn mál. Eins og dæmin hér að neðan sýna heyra íslenska, færeyska og nýnorska saman í slíkum tilfellum gagnstætt dönsku og sænsku. Norskt bókmál fylgir, eins og eðlilegt verður að teljast, stundum dönsku en ekki alltaf. 


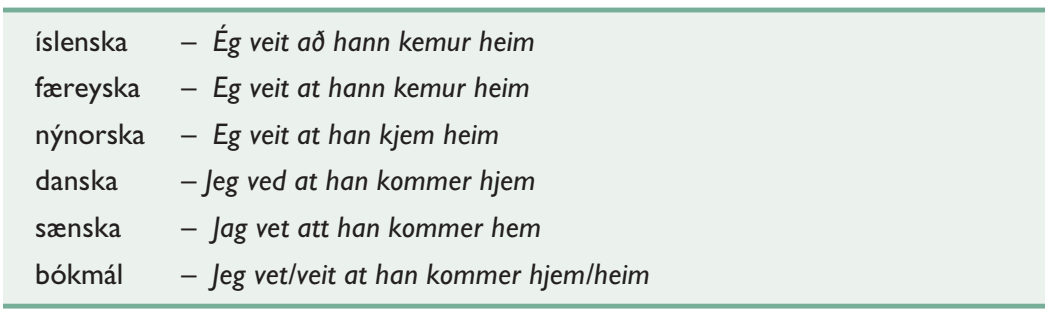

Mynd 16: Dæmi um vesturnorrænan/austurnorrænan mun á norrænum nútímamálum

Hér kemur fram nokkur munur sem hægt er að rekja alveg aftur til skiptingarinnar í vestur- og austurnorræn mál:

1. Fyrstupersónufornafnið með eða án j (ég/eg : jeg/jag),

2. Nútíðarmynd sagnarinnar komme (kemur) með eða án sérhljóðsbreytingar (kemur/kjem : kommer)

3. Síðast en ekki síst tvíhljóð eða einhljóð í orðunum tveimur veit: vet/ved og heim: hem/hjem.

Að mestu leyti var greinarmunurinn á milli norrænu málanna fram á tíma víkinganna frekar ógreinilegur eins og sýnt er fram á með einföldu striki á mynd 15 a.

\section{Á hámiðöldum: Norðurnorræna og suðurnorræna}

Eftir um pað bil 1200 er greinilegt að mikilvægustu skilin - sem sýnd eru með tveimur strikum í mynd 15 b hér að neðan - eru nú á milli dönsku, sem samkvæmt pví ætti að kalla suðurnorrcent mál - og pess sem eftir er af norræna svæðinu sem ætti að kalla norđurnorrcen mál. Áreiðanlega má rekja pað til einhverra samfélagslegra breytinga að mikilvægustu skilin eru orðin öðruvísi. Ef til vill var meira samband við pýsku í Danmörku á sama tíma og petta framandi samband hafði ekki jafnmikil áhrifí Norður-Skandinavíu.

\section{norðurnorræn mál íslenska færeyska norska sænska danska}


Dönsku nýmælin eru að hluta til breytingar sem einnig koma fram síðar í norsku og sænsku - petta á sérstaklega við um einföldun beygingarkerfisins; sbr. kaflann hér á eftir. En pað koma einnig í ljós sérstakar breytingar í dönsku sem ekki er um að ræða í hinum málunum. Par er um að ræða svo kallaða sérhljóđaveiklun sem kemur fram í sérhljóðum í bakstöðuatkvæðum:

- Í dönsku er núna aðeins einn sérhljóði í beygingarendingum, p.e. e. Hið sama gildir að mestu um norskt bókmál.

- Í nýnorsku og sænsku er að auki oft $a$ og í einstaka tilvikum einnig $o$.

- Í íslensku og færeysku er $a$ í næstum öllum sömu myndum og í sænsku og nýnorsku en hins vegar $i$ og $u$ í stað $e$ og $o$.

Sem dæmi um petta má nota fleirtölumyndir nafnorðanna bakkar, synir og visur og nútíðarmynd sagnanna kastar og kennir:

\begin{tabular}{llllll}
\hline íslenska: & bakkar & synir & vísur & kastar & kennir \\
færeyska: & bakkar & synir & vísur & kastar & kennir \\
nýnorska: & bakkar & søner & viser/visor & kastar & kjenner \\
sænska: & backar & söner & visor & kastar & känner \\
bókmál: & bakker & sønner & viser & kaster & kjenner \\
danska: & bakker & sønner & viser & kaster & kender \\
\hline
\end{tabular}

Mynd 17: Dæmi um sérhljóðaveiklun: Munur á atkvæðum í bakstöðu norðurnorrænu og suðurnorrænu

Á pessum tíma verður sérstök próun í dönsku sem aðeins breiðist út í mjög litlum mæli til hinna hluta norræna svæðisins. Detta á m.a. við um próunina á hinum svokölluðu linu eða mjúku samhljóðum, p.e.a.s breytinguna úr $p, t, k i ́ b, d, g$ á eftir sérhljóða. Dæmi um petta eru á dönsku gabe (geispa), bide (bita), kage (kaka) á norsku gape, bite, kake og sænsku gapa, bita, kaka. Pessi breyting kemur einnig fram í mállýskum í Suður- og Vestur-Svípjóð og á suðvesturströnd Noregs, sbr. mynd 12 að framan. Dótt undarlegt sé má finna sömu próun í suðurhluta færeyska og íslenska málsvæðisins svo að ef til vill vakna grunsemdir um að mjúkir samhljóðar séu „sunnlensk“ hugdetta en par sem fjarlægðin á milli Færeyja, Íslands og Suður-Skandinavíu er nokkuð mikil verður að draga pá ályktun að petta sé óháð próun án nokkurs innra samhengis.

En pað verða ýmsar fleiri hljóðbreytingar í dönsku sem ekki koma fram í ritun, t.d. hið svonefnda hljóđrof, en pess í stað er í sænsku og 
norsku orðhreimur eða tónfall. Detta má sjá ef framburður orða á norsku og sænsku er borinn saman við samsvarandi orð á dönsku:

- Orðhreimur 1 í norsku og sænsku, hljóđrofí dönsku: bønder (bændur á dönsku og norsku), anden (no. önd með ákveðnum greini í sænsku).

- Orðhreimur 2 í norsku og sænsku, ekki hljóđrofí dönsku: bønner (baunir á dönsku og norsku); anden (no. andi með ákveðnum greini í sænsku).

- Í íslensku og færeysku er hvorki orðhreimur né hljóðrof.

\section{Orðhreimur og hljóðrof}

Orőhreimur segir til um tónfall sem hefur áhrif á merkingu orða. Við hljóðrof er raddböndunum aftur á móti næstum pví lokað, p.e.a.s. loftstreymið er næstum pví stöðvað í barkanum en síðan opnað skyndilega aftur.

Вæði orðhreimur og hljóðrof eru sem sagt svolítið annað en málhljóð - einn sérhljóði eða einn samhljóði - og ekki heldur pað sama og áhersla vegna pess að i öllum dæmunum hér að framan er áherslan á fyrsta atkvæðinu en í orðum eins og idé (hugmynd) eða hotell (hótel) er áherslan venjulega á síđasta atkvæðinu.

Orðhreimur er sjaldgæft fyrirbæri í Evrópu - i Vestur Evrópumálum er pađ aðeins til í norsku og sænsku. Hins vegar er orðhreimur afar algengur í öðrum heimshlutum, t.d. í Afríku og i AusturAsíu. Í pví máli í heiminum, sem talað er af flestum - mandarínkínversku, eru t.d. fjórir mismunandi orðhreimar.
Orðhreimar í norsku og sænsku eru sennilega um pað bil púsund ára. Venjulega er talið að danska hljóðrofið hafi komið af öðru eldra kerfi með orðhreimi eins og í norsku og sænsku. Hvenær hljóðrofið kom fyrst fram í dönsku er ekki gott að segja vegna pess að pað er ekki sýnt í ritun en allt bendir til pess að pað hafi verið í málinu síðan á miðöldum. Elstu skriflegu vísbendingarnar um að hljóðrof hafi komið fram í dönsku eru frá 1510 pegar sænski biskupinn Hemming Gadh lýsti framburði Dana með nokkurri lítilsvirðingu á eftirfarandi hátt í anddanskri ræðu:

Der til med så wärdas de icke heller tala som annat folck, uthan tryckia ordhen fram, lika som the willia hosta. (= Par fyrir utan nenna peir ekki að tala eins og annað fólk heldur prýsta orðunum út eins og peir ætli að hósta.) 
Eins og sjá má af mynd 15 b eru engar línur sem skilja á milli norsku og hinna tveggja norsku ,útflytjendamálanna“ íslensku og færeysku. Strangt til tekið er petta smá svindl vegna pess að vitað er að pað var dálítill munur á íslensku og norsku pegar fyrir árið 1200. En á prettándu öld og fram á pá fjórtándu var pessi munur áreiðanlega minni en skilin á milli hinna ólíku mála innan Skandinavíu.

\section{Nýir tímar: Eyjanorræna og skandinavíska}

Pegar nær dregur aldamótunum 1500 verður myndin aftur á móti allt önnur. Pá fara aðalskilin innan norrænna mála að verða á milli pessara priggja, íslensku, færeysku og norsku. •að segir sig sjálft að slíkur munur verður ekki til á einni nóttu heldur próast stig af stigi á löngum tíma.

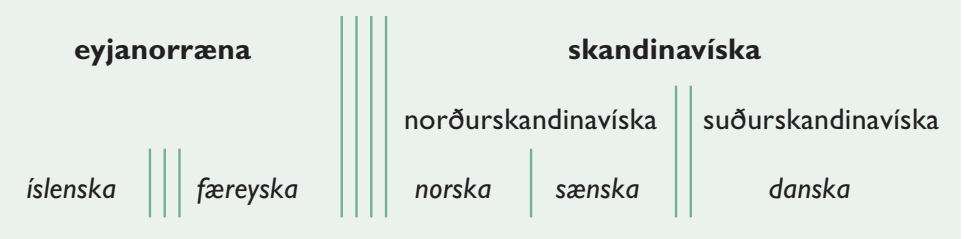

Mynd 15 c: Skipting norrænna mála eftir u.p.b. 1500

Ástæða pess að ný skipting verður til er að nú kemur í ljós að hin mikla landfræðilega fjarlægð á milli Skandinavíu og eyjasamfélaganna í Atlantshafi hefur áhrif á samskiptin. Að sönnu voru talsverð samskipti á milli samfélaga útflytjendanna og gamla föðurlandsins Noregs fyrstu aldirnar eftir fólksflutningana á níundu og tíundu öld. En eftir u.p.b. 1300 fóru pau síminnkandi og á síðari tímum fóru samskiptin við Skandinavíu í auknum mæli um Danmörku par eð Kaupmannahöfn var orðin höfuðborgin í dansknorska konungdæminu. Pá voru pau samskipti, sem fram fóru, að mestu leyti við danska embættis- og verslunarmenn sem voru ekki margir og samskipti peirra við heimamenn af skornum skammti.

Talmálið í Skandinavíu breyttist mikið á síðmiðöldum en að mestu leyti ,í takt" á pann hátt að munurinn innan Skandinavíu jókst ekki mikið. Breytingar á báðum norrænu eyjamálunum voru hins vegar miklu minni. Sérstaklega á petta við um íslensku sem er íhaldssamasta mál allra germanskra mála. 
Niðurstaða pessa er að mismunur á málum pessara priggja landfræðilega aðskildu svæða verður meiri en fyrri mállýskumunur norrænna mála. Mikilvægustu skilin liggja nú á milli eyjanorrcenu og skandinavisku, táknuð með fjórum strikum, og par á eftir á milli íslensku og færeysku, táknuð með premur strikum. Munurinn á pessum premur svæðum - Íslandi, Færeyjum og Skandinavíu - er nú orðinn svo mikill að gagnkvæmur skilningur peirra á milli finnst ekki lengur. Detta á að minnsta kosti við um ystu svæðin - p.e.a.s. íslensku og skandinavísku. Færeyingar, sem eru bæði í málfarslegum og landfræðilegum skilningi í miðjunni, hafa ákveðin tækifæri til pess að skilja íslensku og skandinavísku í nánast öllum útgáfum, fyrst og fremst vegna pess að mikil áhersla er lögð á dönskukennslu en færeyski framburðurinn minnir meira á pann norska og sænska en pann danska. Færeyingar hafa pess vegna bestu skilyrðin til pess að skilja öll norrænu málin.

Gagnkvæmur skilningur á milli íslensku og færeysku er hins vegar pegar best læutur aðeins í aðra áttina - Íslendingar skilja lítið í færeysku. Eins og áður hefur komið fram getur petta m.a. stafað af pví að færeyska málsamfélagið er miklu minna en pað íslenska.

Innan Skandinavíu ríkir aftur á móti ennpá gagnkvæmur skilningur eins og verið hafði innan alls norræna málsvæðisins áður fyrr. Аð pessu pema verður komið aftur í lok greinarinnar.

\section{Hvers vegna eru skandinavíska og eyjanorræna fjarlægðarmállýskur?}

Málin, sem teljast til eyjanorrænu, eru, eins og fram hefur komið, íhaldssömustu norrænu málin og pað á sérstaklega við um íslensku. Færeyska lendir á margan hátt mitt á milli málanna sem auðveldlega má sjá t.d. ef beygingarkerfi innan svæðanna priggja eru borin saman.

\section{Mismunandi beyging}

Á miðöldum og fyrr fengu bæði nafnorð, lýsingarorð og fornöfn ólíkar myndir eftir pví hvernig pau voru notuð í setningum - sem frumlag, andlag eða á eftir ýmsum forsetningum og svo framvegis. Í norrænu og öðrum germönskum málum voru fjögur föll - nefnifall (nf.), polfall (pf.), págufall (pgf.) og eignarfall (ef.). Öll pessi föll eru enn pá til í íslensku - og pýsku sem einnig hefur haldið mörgum gömlum beygingarmyndum. Í færeysku er eignarfallið eiginlega alveg horfið og í skandinavísku eru öll föll nafnorða horfin. 


\section{Athugasemd um eignarfall}

Margir halda pví fram að eignarfall sé ennpá til sem fall í nútímaskandinavískum málum í formi hinnar vel pekktu s-endingar eins og í Gunnars hest sem í fornnorrænu hefði heitið annaðhvort Gunnars hestr eða hestr Gunnars. En petta s hegðar sér frekar eins og sérstakt orð en ending á nafnorði vegna pess að par sem pað er Gunnar á Hlíđarenda sem á hestinn, pá er sagt á nútíma skandinavísku „Gunnar på Lidarendes hest“. Pá kemur í ljós að s-ið er bundið við allt orđasambandið Gunnar på Lidar- ende. Í norrænu - og á íslensku - er petta aftur á móti: ,hestr (nútímaíslenska: hestur) Gunnars á Hliðarenda“. Sjá má að s-ið er aðeins bundið við aðalorðið Gunnar.

Par fyrir utan er aðeins hægt að nota s-eignarfall til að tákna eign; í allri annarri notkun (t.d. á eftir ákveðnum forsetningum) er eignarfall ekki lengur notað (t.d. til byen (í bæinn), ekki til bys (í bæs), en er aftur á móti varðveitt í ákveðnum orđasamböndum til lands, til fots (fótgangandi) o.s.frv).

Hér á eftir verður sýnt hvernig beygingar koma fram í mismunandi málum; til pess að sýna beygingarmyndir í færeysku og íslensku eru forsetningar sem taka með sér viðkomandi fall teknar með:

\begin{tabular}{|c|c|c|c|}
\hline & $\begin{array}{l}\text { skandinavíska } \\
\text { - norska }\end{array}$ & færeyska & íslenska \\
\hline \multicolumn{4}{|l|}{ eintala } \\
\hline & hest & hestur (nf.) & hestur (nf.) \\
\hline & om hest & um hest (pf.) & um hest (pf.) \\
\hline & fra hest & frá hesti ( pgf.) & frá hesti ( pgf.) \\
\hline & til hest & til hest (bf.) & til hests (ef.) \\
\hline \multicolumn{4}{|l|}{ fleirtala } \\
\hline & hester & hestar (nf.) & hestar (nf.) \\
\hline & om hester & um hestar (bf.) & um hesta (pf.) \\
\hline & fra hester & frá hestum (pgf.) & frá hestum (pgf.) \\
\hline & til hester & til hestar (pf.) & til hesta (ef.) \\
\hline
\end{tabular}

Mynd 18: Beygingarmyndir í skandinavísku, færeysku og íslensku

Í skandinavísku má enn finna leifar af beygingum fornafna; sbr. jeg ser deg (ég sé pig) : du ser meg, (pú sérð mig) par sem myndirnar $\mathrm{jeg} / \mathrm{meg}(\dot{e} \mathrm{~g} / \mathrm{mig})$ og $d u / d e g(b u ́ / p i g)$ eru annars vegar frumlag og hins vegar andlag, eitthvað sem eru leifar af skilum milli nefnifalls/polfalls. 
Í eldri málum og ennpá í eyjanorrænu eru ekki aðeins skil á milli mismunandi málfræðilegra kynja í eintölu í fornöfnum eins og han (hann) og hun (hún), heldur einnig í fleirtölu. Fornöfnin taka á sig prjár ólíkar myndir allt eftir pví hvort pau vísa til persóna af karlkyni, kvenkyni eða hvorugkyni. betta er sýnt með setningardæmum hér á eftir par sem hægt er að pýða orðið de (peir, paer, pau) á prenns konar hátt:

\begin{tabular}{llll}
\hline & $\begin{array}{l}\text { skandinavíska } \\
\text { - norska }\end{array}$ & færeyska & íslenska \\
\hline karlkyn & guttene: & dreingirnir: & strákarnir: \\
& de & teir & peir \\
\hline kvenkyn & jentene: & genturnar: & stelpurnar: \\
& de & tær & pær \\
\hline karlkyn + & guttene og & dreingirnir og & strákarnir og \\
kvenkyn & jentene: & genturnar: & stelpurnar: \\
& de & tey & pau \\
\hline
\end{tabular}

Mynd 19: Fornöfn í priðju persónu fleirtölu

Sagnir höfðu í eldri norrænu mismunandi myndir eftir pví hvort frumlagið var í eintölu eða fleirtölu eða hvort frumlagið var fornafn í 1. eða 2. persónu; sbr. ensku the boy comes : the boys come og I am : you are. Í íslensku hafa bæði beygingar eftir persónu og tölu varðveist. Í færeysku er aftur á móti ekki lengur til beyging eftir persónu í fleirtölu en í nútíma skandinavískum málum beygjast sagnir hvorki eftir persónu né tölu.

\begin{tabular}{llll}
\hline & $\begin{array}{l}\text { skandinavíska } \\
- \text { norska }\end{array}$ & færeyska & íslenska \\
\hline eintala & & & \\
\hline 1. persóna & jeg står & eg standi & ég stend \\
\hline 2. persóna & du står & tú stendur & pú stendur \\
\hline 3. persóna & han/hun står & han/hon stendur & hann/hún stendur \\
\hline fleirtala & & & \\
\hline 1. persóna & vi står & vit standa & við stöndum \\
\hline 2. persóna & dere står & tit standa & pið standið \\
\hline 3. persóna & de står & teir/tær/tey standa & peir/pær/pau standa \\
\hline
\end{tabular}

Mynd 20: Beyging sagna eftir persónu og tölu 
Í sænska ritmálinu var beygt eftir tölu alveg fram á miðja tuttugustu öld (pojken kommer (drengurinn kemur): pojkarna komma (drengirnir koma)), en beygingin hvarf úr ritaðri dönsku og norsku pegar á nítjándu öld. Hér á eftir fer yfirlit yfir mismuninn:

\begin{tabular}{|c|c|c|c|}
\hline ísle & & færeyska & skandinavíska \\
\hline \multicolumn{4}{|l|}{ fjöldi falla } \\
\hline a) nafnorða og lýsingaorða & 4 & 3 & 0 \\
\hline b) fornafna & 4 & 3 & 2 \\
\hline Beygt eftir kyni i ft. & + & + & - \\
\hline Sagnir beygðar eftir tölu & + & + & - \\
\hline a) í eintölu & + & + & - \\
\hline b) í fleirtölu & + & - & - \\
\hline
\end{tabular}

Mynd 21: Yfirlit yfir beygingarform í skandinavísku og eyjanorrænu

Í setningunum fyrir neðan má sjá hvernig allt pað sem um hefur verið fjallað hér að ofan virkar í raun:

\section{ÍSLENSKA}

Eins og sjá má á mynd 21 er íslenska eina norræna málið par sem sagnir beygjast bæði í eintölu og fleirtölu og nafnorð beygjast í fjórum föllum. Í dæmunum hér á eftir er sýnt hvernig petta virkar með sögnunum koma, sjá, standa og sakna sem standa með nafnorðinu hestur sem beygt er í öllum föllum með ákveðnum greini í eintölu og fleirtölu par sem mismunandi persónufornöfn eru frumlag.

\begin{tabular}{llll}
\hline EINTALA & & & \\
\hline nefnifall & hesturinn kemur & & \\
\hline & polfall (pf.) & págufall (pgf.) & eignarfall (ef.) \\
\hline 1.persóna & ég sé hestinn & ég stend hjá hestinum & ég sakna hestsins \\
\hline 2. persóna & pú sérð hestinn & pú stendur hjá hestinum & pú saknar hestsins \\
\hline 3. persóna & hann/hún & hann/hún & hann/hún \\
& sér hestinn & stendur hjá hestinum & saknar hestsins \\
\hline
\end{tabular}




\begin{tabular}{llll}
\hline \multicolumn{2}{l}{ FLEIRTALA } & & \\
\hline nefnifall (nf.) & hestarnir koma & \\
\hline & polfall (pf.) & págufall (pgf.) & eignarfall (ef.) \\
\hline 1. persóna & $\begin{array}{l}\text { við sjáum } \\
\text { hestana }\end{array}$ & $\begin{array}{l}\text { við stöndum hjá } \\
\text { hestunum }\end{array}$ & $\begin{array}{l}\text { við söknum } \\
\text { hestanna }\end{array}$ \\
\hline 2. persóna & pið sjáið hestana & pið standið hjá hestunum & pið saknið hestanna \\
\hline 3. persóna & $\begin{array}{l}\text { peir/pær/pau } \\
\text { sjá hestana }\end{array}$ & $\begin{array}{l}\text { peir/pær/pau standa } \\
\text { hjá hestunum }\end{array}$ & $\begin{array}{l}\text { peir/pær/pau } \\
\text { sakna hestanna }\end{array}$ \\
\hline
\end{tabular}

\section{FÆREYSKA}

Ef sömu setningar eru skoðaðar í færeysku kemur fram tvenns konar munur:

a) Eignarfall nafnorðsins er horfið (sbr. eg síggi/sakni hestin (polfall) en í íslensku: ég sé hestinn (polfall) en ég sakna hestsins (eignarfall) - á íslensku stendur andlag sagnarinnar sakna alltaf í eignarfalli).

b) Beyging sagnarinnar eftir persónu er horfin í fleirtölu (öll fleirtöluformin enda á -a: síggja, standa, sakna; en á íslensku sjáum sjáið-sjá; stöndum-standið-standa; söknum-saknið-sakna).

\begin{tabular}{llll}
\hline \multicolumn{2}{l}{ EINTALA } & & \\
\hline nefnifall & hesturin kemur & & \\
\hline & polfall (pf.) & págufall (pgf.) & polfall (pf.) \\
\hline 1. persóna & eg síggi hestin & eg standi hjá hestinum & eg sakni hestin \\
\hline 2. persóna & tú sært hestin & tú stendur hjá hestinum & tú saknar hestin \\
\hline 3. persóna & $\begin{array}{l}\text { hann/hon sær } \\
\text { hestin }\end{array}$ & $\begin{array}{l}\text { hann/hon stendur } \\
\text { hjá hestinum }\end{array}$ & $\begin{array}{l}\text { hann/hon saknar } \\
\text { hestin }\end{array}$ \\
\hline
\end{tabular}

\begin{tabular}{llll}
\hline FLEIRTALA & \multicolumn{3}{l}{} \\
\hline nefnifall & hestarnir (nf.) koma & \\
\hline & polfall (pf.) & págufall (pgf.) & polfall (pf.) \\
\hline 1. persóna & vit síggja hestarnar & vit standa hjá hestunum & vit sakna hestarnar \\
\hline 2. persóna & tit síggja hestarnar & tit standa hjá hestunum & tit sakna hestarnar \\
\hline 3. persóna & teir/tær/tey síggja & teir/tær/tey standa & teir/tær/tey sakna \\
& hestarnar & hjá hestunum & hestarnar \\
\hline
\end{tabular}


NORSKT BÓKMÁL

Hér á eftir sjáum við skandinavíska nútímakerfið án beygingar nafnorða og án beygingar sagna eftir persónu og tölu.

\begin{tabular}{|c|c|c|c|}
\hline \multicolumn{4}{|l|}{ EINTALA } \\
\hline & hesten komme & & \\
\hline 1.persóna & jeg ser hesten & jeg står hos hesten & jeg sakner hesten \\
\hline 2. persóna & du ser hesten & du står hos hesten & du sakner hesten \\
\hline 3.persóna & $\begin{array}{l}\text { han/hun ser } \\
\text { hesten }\end{array}$ & $\begin{array}{l}\text { han/hun står } \\
\text { hos hesten }\end{array}$ & $\begin{array}{l}\text { han/hun sakner } \\
\text { hesten }\end{array}$ \\
\hline
\end{tabular}

\begin{tabular}{llll}
\hline FLEIRTALA & & \\
\hline & hestene kommer & \\
\hline 1.persóna & vi ser hestene & vi står hos hestene & vi sakner hestene \\
\hline 2. persóna & dere ser hestene & dere står hos hestene & dere sakner hestene \\
\hline 3. persóna & de ser hestene & de står hos hestene & de sakner hestene
\end{tabular}

Sé sameiginlega norræna málið lagt til grundvallar í samanburðinum er hægt að slá pví föstu að í íslensku hefur beygingarkerfið varðveist næstum óbreytt síðustu púsund ár en í færeysku hefur hluti af gömlu beygingarmyndunum horfið en ekki nærri pví jafnmikið og í skandinavísku málunum.

\section{Mismunandi framburður}

раð er samt sem áður ekki aðallega munur á beygingarkerfinu p.e.a.s. beygingarmyndum - sem greinir íslensku og færeysku frá skandinavísku málunum. Tvö önnur málleg svið eru án efa langtum mikilvægari. Annað varðar hljóðin og hitt orðaforðann. Dessi munur kemur vel fram pegar setningarnar prjár hér fyrir neðan eru skoðaðar: a-gerðin er venjuleg íslensk stafsetning, b-gerðin er sama setningin hljóðrituð en c-gerðin er pýðing á norsku: 
1. a. Konan talaði við manninn sinn um bílinn.

b. /ko:nan ta:laði vi:ð man:in sin Ym bi:Iın/

c. Kona talte med mannen sin om bilen.

2. a. Kerlingin mætti tröllinu á fjallinu.

b. /kjerdlingjin mai ${ }^{h_{t}}$ :I trødlınY au fjadlınY/

c. Kjerringa møtte trollet på fjellet.

3. a. Sjónvarpið bilaði pegar ég var að horfa á fréttirnar.

b. /sjou:nvarpið bl:laðı pe:yar je: $\gamma$ va:r að horva au frjeht:Irdnar/

c. Fjernsynet gikk i stykker mens jeg så på nyhetene.

Mynd 22: Íslenska (rituð og töluð) í samanburði við skandinavísku

Af pessum íslensku setningum er nr. 1 sennilega skiljanleg flestum Skandinövum bæði skrifuð og töluð, nr. 2 væri pað varla töluð en sennilega skrifuð og nr. 3 áreiðanlega alveg óskiljanleg hvort sem um væri að ræða í rituðu máli eða töluðu. Útskýringin er einnig alveg augljós:

- Í nr. 1: Konan talaði við manninn sinn um bílinn, eru orðin sjálf nákvæmlega eins og hljóðin eru frekar svipuð.

- Í nr. 2: Kerlingin meetti tröllinu á fjallinu, eru orðin líka hin sömu en próun hljóðanna í íslensku og skandinavísku hefur gert orðin frekar ópekkjanleg fyrir Skandinava ef hann fær aðeins að heyra setninguna en skriflega gerðin er alls ekki jafn framandi.

- Í nr. 3: Sjónvarpið bilađi pegar ég var ađ horfa á fréttirnar, eru hins vegar næstum pví öll orðin önnur og pá skiptir engu hvort hljóðpróun eða allar aðrar aðstæður eigi við.

\section{Orđin ráđa mestu um skilninginn}

Afar mikilvæg og ef til vill mikilvægasta forsenda skilnings á milli mála er sem sagt að orðin séu lík, annaðhvort í töluðu máli eða rituðu - eða helst hvort tveggja. Í skandinavísku var stórum hluta af norrænu erfðaorðunum skipt út á síðmiðöldum og í stað peirra komu lágpýsk orð. Aðalorsök pessa voru mikil samskipti við hansakaupmenn, p.e.a.s. norðurpýska kaupmenn, sem lengi voru alls- 
ráðandi í viðskiptum um alla Skandinavíu. Og pessi samskipti hafa skilið eftir sig ákveðin spor. Sé frekar varlega áætlað koma um pað bil 30 til 40 prósent af daglegum orðaforða í skandinavísku úr lágpýsku.

\section{Skandinavísk nútímamál hafa mörg pýsk tökuorð}

Hægt er að semja heilan texta par sem næstum pví allt nema málfræðiendingarnar og smáorð eru pýsk eins og í setningunni hér á eftir, par sem aðeins undirstrikuðu orðin eru norræn en pýsk tökuorð pað sem eftir er.
Skredderen mente at jakka passet fortreffelig, men kunden klaget over at plagget var kort og tøyet simpelt og grovt. (Klæðskeranum fannst jakkinn fara ljómandi vel en viðskiptavinurinn kvartaði yfir að flíkin væri stutt og efnið lélegt og gróft).

Ein af ástæðunum fyrir vandamálum í málskilningi í Skandinavíu er að ólík orð hafa verið tekin að láni úr lágpýsku í Noregi, Svípjóð og Danmörku. Ef á heildina er litið dreifast pýsku orðin í nútímaskandinavísku sennilega frekar jafnt á hin ólíku mál - en pegar orðalagið er mismunandi er valið í norsku og dönsku venjulega eins og annað en í sænsku. Ástæða pess er einfaldlega sú að í mörg hundruð ár var danska ritmál bæði í Danmörku og Noregi. Dar sem Danir voru næstu nágrannar hansakaupmannanna í Skandinavíu er eðlilegt að pýsku áhrifin hafi orðið sterkust í dönsku og mörg pýsku orðanna hafa án efa ratað yfir í norsku í gegnum danskt ritmál. En Norðmenn áttu líka milliliðalaus viðskipti við hansakaupmennina, sérstaklega í Björgvin, sem fram undir nítjándu öld var stærsti bærinn í Noregi. Svíar hafa hins vegar fengið pýsk orð um hansabæi sína eins og Stokkhólm og Kalmar og pað eru oftar en ekki önnur pýsk orð en pau sem bárust í dönsku og norsku.

Í töflunni hér að aftan má greinilega sjá hve lík dönsku og norsku orðin eru - sama hvort um er að ræða nýnorsku eða bókmál - en sænska hefur önnur orð yfir sömu hugtök. Dað sem er líkt og ólíkt er að hluta til vegna pess að norska/ danska annars vegar og sænska hins vegar nota ýmist norrænt eða pýskt orð en mismunurinn getur einnig stafað af pví að mismunandi norræn eða pýsk orð eru notuð í málunum. 


\begin{tabular}{|c|c|c|}
\hline norska & danska & sænska \\
\hline spørje/spørre & spørge & fråga \\
\hline \multicolumn{2}{|c|}{ frá spyrja (norræna) } & frá frâgen (lágpýska) \\
\hline vindauge/vindu & vindue & fönster \\
\hline \multicolumn{2}{|c|}{ frá vindauga (norræna) } & frá fenster (lágbýska) \\
\hline mangel & mangel & brist \\
\hline \multicolumn{2}{|c|}{ fra mangel (lágpýska) } & frá brist (fornsænska) \\
\hline stilling & stilling & läge \\
\hline \multicolumn{2}{|c|}{ frá stelling (lágpýska) } & frá læghe (fornsænska) \\
\hline nå & nå & hinna \\
\hline \multicolumn{2}{|c|}{ frá ná (norræna) } & frá hinna (fornsænska) \\
\hline samfunn & samfund & samhälle \\
\hline \multicolumn{2}{|c|}{ frá samfundr (norræna) } & frá samhælde (fornsænska) \\
\hline omtrent & omtrent & ungefär \\
\hline \multicolumn{2}{|c|}{ frá umtrent (lágpýska) } & frá ungefêr (lágpýska) \\
\hline oppdage & opdage & upptäcka \\
\hline \multicolumn{2}{|c|}{ frá updagen (lágpýska) } & frá updecken (lágpýska) \\
\hline
\end{tabular}

Mynd 23: Dæmi um mismunandi orðaforða í norsku og dönsku annars vegar en sænsku hins vegar. Fyrir neðan hvert orð stendur hið norræna/fornsænska eða lágpýska orð sem nútímamálið á uppruna sinn að rekja til. Í fyrstu dæmunum fjórum felst mismunurinn í að norska/danska annars vegar og sænska hins vegar hafa valið norrænt eða pýskt orð - eða öfugt. Í næstu tveimur dæmum eru öll orðin norræn - en um er að ræða tvö mismunandi norræn orð. Í síðustu dæmunum tveimur eiga öll orðin rætur að rekja til lágpýsku en aftur á móti til mismunandi orða.

\section{Er ættartréð úr sér gengið?}

Eins og fram kom á mynd 5 er skipting norrænna mála á ættartrénu misvísandi fyrst og fremst vegna pess að par fylgir norska íslensku og færeysku sem „vesturnorrænt mál“. Detta er ekki sú skipting sem við teljum eðlilegasta núna. Spurningin er hvort ekki ætti að gefa ættartréð upp á bátinn og nota bylgjukenninguna sem lítur út fyrir að vera nákvæmari og fjölpættari.

Of fljótt er hins vegar að draga slíka ályktun. Ættartréð er ennpá besta verkfærið sem hægt er að nota til pess að sýna á skýran hátt í hverju sögulegt samhengi í tilteknu málsamfélagi felst. Dað sem er 
sérstaklega mikilvægt er að með ættartrénu er hægt að sýna hvaða samsvaranir í máli eru vegna skyldleika mála af sameiginlegum uppruna - arfs - og hvaða samsvaranir eiga rætur sínar að rekja til samskipta - eða láns. Detta telst mikilvægur munur í samanburðarmálvísindum og um leið verður ættartréð ómissandi undirstaða peirra vísinda. Ef útskýring á pví hvers vegna ný blæbrigði koma fram í málum er takmörkuð við mynd af „öldum“ sem „skvampa“ frjálst hingað og pangað verða arfur og lán hugtök án merkingar í málvísindum og pað teljast varla vísindalegar framfarir.

Vera má að ættartréð líti út fyrir að vera allundarleg skipting norrænna nútímamála - í dag er pað alls ekki pannig að norska sé líkari íslensku og færeysku en sænsku og dönsku. En skýringin liggur í pví að skipting norræna málsvæðisins á ættartrénu í vesturnorrcen mál og austurnorraen mál - p.e.a.s. mynd 4 sem sýnir próun hins frumevrópska máls og evrópskra mála eins og pau eru í dag - á við á tímabili pegar norrænu tungumálin tilheyrðu ennpá einni mállýskusamfellu í Skandinavíu - áđur en nokkrir fólksflutningar urðu pess valdandi að fólk tók sér búsetu á fjarlægum svæðum.

Dað sem gerðist næst var að hluti norrænna manna - nánar tiltekið hluti Norðmanna - flutti frá Noregi til eyjanna í vestri. En peir sem fóru til Færeyja og Íslands voru auðvitað ekki allir peir sem töluðu „,vesturnorrænu“ - stærstur hluti peirra varð eftir í Noregi. Dessir fólksflutningar urðu til pess að smám saman „rifnaði“ vesturnorræna greinin í marga hluta par sen samskipti á milli brottfluttra og peirra sem eftir urðu féllu meira eða minna niður á sama tíma og samskipti innan Skandinavíu héldu áfram eins og ekkert hefði í skorist. Detta er ástæða pess að hugtökin austur- og vesturnorræn mál ná skammt pegar lýsa á sambandinu á milli norrænu málanna í dag.

próun norrænna mála sýnir að pað getur verið vafasamt að teikna ættartré yfir mállýskusamfellu ef pess er vænst að ættartréð sýni um ókomin ár raunverulegan skyldleika á milli mismunandi „greina“. Hætta er á að greinarnar flækist pegar slík samfella klofnar upp vegna brottflutnings til fjarlægra svæða. 


\section{Skilningur milli skandinavískra grannmála - ađalatriði norrænnar samkenndar}

Degar Danir, Norðmenn og Svíar (að Finnlandssvíum meðtöldum) tala saman nota peir venjulega móðurmál sín með smá samstillingu í orðavali og framburði. Deir sem tala skandinavísk mál hegða sér í raun eins og skandinavísku málin séu „aðeins mállýskur“. Deir gera með öðrum orðum ráð fyrir pvi að viðmælandinn skilji mál nágrannans. Detta er hefðbundin mynd af svokölluðum samskiptum grannmála.

Eins og áður hefur komið fram er staða Norðmanna sérstaklega hentug par sem peir eiga mestan hluta orðaforðans sameiginlegan með Dönum vegna langvarandi ritmálssambands en um leið eiga peir framburðinn að mestu sameiginlega með Svíum. Detta ræður greinilega úrslitum varðandi hæfileikann til pess að skilja nágrannamálin. Hér er skýringarmynd sem sýnir hve mikið fólk frá mismunandi skandinavískum löndum skilur af töluðu grannmáli:

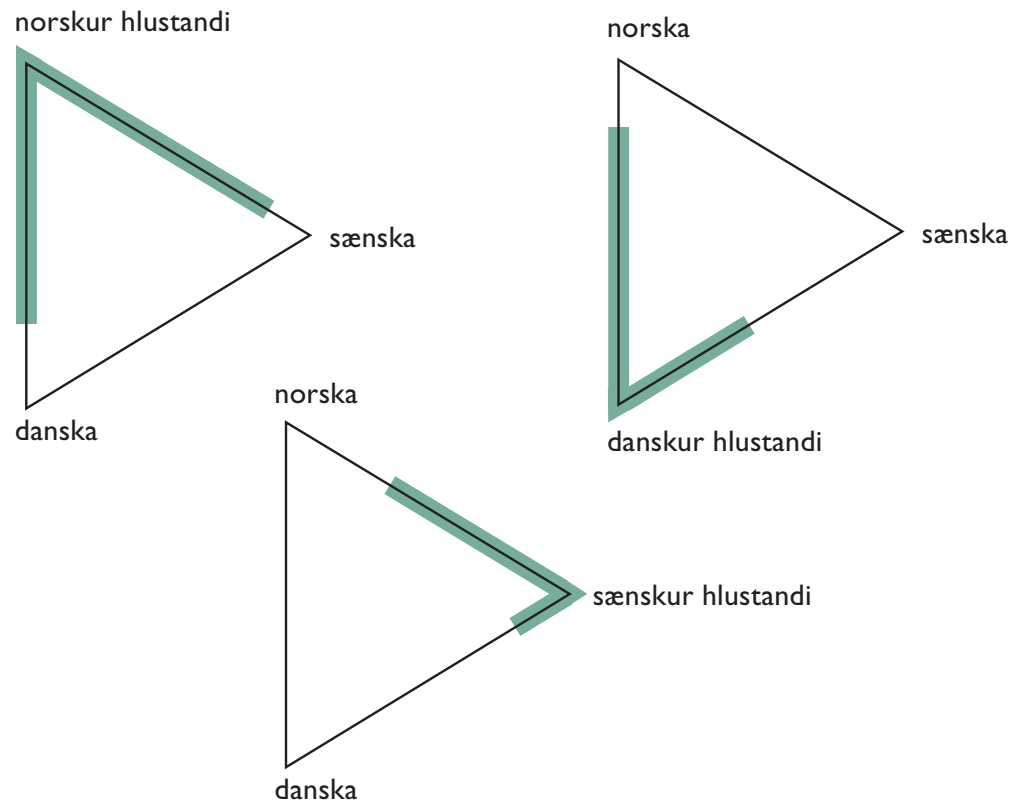

Mynd 24: Skilningur á skandinavískum grannmálum 
Yfirlitið byggist á rannsókn á dönskum, norskum og sænskum nýliðum í hernum, p.e. u.p.b. 19 ára piltum, sem gerð var í upphafi áttunda áratugar síðustu aldar. Eins og fram kemur stóðu norsku piltarnir feti framar en bæði Danir og Svíar en einnig má sjá að peir síðastnefndu reka óumdeilanlega lestina. Deir skildu miklu minna af bæði norsku og (sérstaklega) dönsku. Eins og áður hefur verið nefnt getur petta verið afleiðing hefðbundinnar stórabróðursáráttu Svía - par sem peir eru svo margir gera peir ráð fyrir að fámennari nágrannar leggi á sig pað „erfiði“ að skilja sænsku um leið og peir sjálfir nenna ekki að reyna að skilja dönsku og norsku, svo gefin sé eilítið ógeðfelld túlkun af „skekkjunni“ í skilningi Svía á grannmálum annars vegar og nágranna peirra í suðri og vestri hins vegar.

Detta er aftur á móti ekki allur sannleikurinn. Í umræddri rannsókn var einungis stuðst við upplýsingar frá nýliðum af höfuðborgarsvæðum hinna priggja hlutaðeigandi landa og pað mun nánast sjálfvirkt vera málskilningi Dana og Norðmanna í hag vegna pess að bæði Osló og sérstaklega Kaupmannahöfn eru mjög nálægt Svípjóð en Stokkhólmur er langt frá bæði Noregi og Danmörku. Баð parf pví ekki að koma á óvart að íbúar Stokkhólms skilji minna í dönsku og norsku en íbúar Kaupmannahafnar og Oslóar skilja í sænsku einfaldlega vegna pess að Kaupmannahafnar- og Oslóarbúar hitta Svía langtum oftar vegna næsta nágrennis við Svípjóð.

Önnur staðreynd, sem án efa var mikilvæg á áttunda áratugnum, var sjónvarpið. Bæði Kaupmannahafnar- og Oslóarbúar áttu pess kost tæknilega að horfa á sænskt sjónvarp - eins og margir peirra gerðu - en íbúar Stokkhólms gátu hvorki horft á danskar né norskar sjónvarpsútsendingar. Á pann hátt fengu margir Danir og Norðmenn næstum ótakmarkaða ókeypis „,sænskukennslu“ á sama tíma og engin leið var fær í hina áttina.

Í nýrri rannsókn á skilningi á grannmálum, sem ennpá er ekki lokið, hefur verið reynt að rétta af petta „óréttlæti“ gagnvart Svíum með pví að tryggja jafnari landfræðilega nálgun á upplýsingum á pann hátt að íbúar í Björgvin í Noregi, Árósum í Danmörku og Málmey í Svípjóð eru teknir með í samanburðinum. Detta hefur, eins og menn máttu eiga von á, haft í för með sér að færni Dana og Svía til að skilja hina lítur út fyrir að vera jafnari en í eldri rannsókninni. Norðmenn eru hins vegar greinilega í fararbroddi sem kemur ekki á óvart sé tekið tillit til pess hvað er líkt og ólíkt með skandinavísku málunum premur. Eins og áður hefur komið fram, talsvert einfaldað, eiga Norðmenn framburðinn sameiginlegan 
með Svíum og orðaforðann með Dönum.

Degar Norðmaður talar við Svía eru pað aðeins „sérsænsk“ orð sem valda vandræðum á meðan framburðurinn er oftast ekkert vandamál. Í samræðum við Dana er pessu öfugt farið, pá eru orðin að mestu leyti hin sömu og í norsku en danski framburðurinn er svo frábrugðinn að pau samskipti eru erfiðari fyrir flesta.

Frá dönskum sjónarhóli séð hljóma norska og sænska svo líkt að flestir Danir eru ekki færir um að greina á milli peirra. Venjulega halda Danir pess vegna að um sé að ræða sænsku pegar peir hlusta á norsku, og par sem peir heyra ekki mun eru tvöfalt meiri líkur á að peir geti rétt pegar peir giska á sænsku vegna pess að pað eru tvöfalt fleiri Svíar í heiminum en Norðmenn.

prátt fyrir petta sýna báđar rannsóknirnar að Danir skilja norsku greinilega betur en sænsku jafnvel pótt peir heyri engan mismun. Detta er auðvitað hinum sameiginlega orðaforða peirra og Norðmanna að pakka. Í gamni er hægt að segja að frá dönskum sjónarhóli sé Norðmaður Svíi sem auðvelt er að skilja! Par með er líka eðlilegt að Svíi og Dani eigi í mestum vandræðum með að skilja hvor annan vegna pess að um er að ræða talsverðan mun bæði hvað varðar orðaforða og framburð en Norðmenn lenda í eftirsóknarverðri stöðu mitt á milli hins „,danska“ orðaforða og hins „sænska“ framburðar.

Auk fjarlægðar milli grannmálanna skýrir enn ein staðreynd pað hvers vegna Norðmenn koma svona vel út. Eins og oft hefur komið fram eru staðbundnar mállýskur mun algengari í Noregi en í nágrannalöndunum. Betta hefur í för með sér að allir Norðmenn eru vanari að heyra dagsdaglega margs konar norsku á meðan Danir og Svíar heyra í mesta lagi tvær útgáfur af móðurmálinu, ríkismálið og ef til vill sína eigin mállýsku. Detta er ef til vill einnig skýring á pví hvers vegna Danir og Svíar gefast frekar upp í tungumálasamskiptum við nágranna sína.

Dar sem Norðmenn eru svo vanir málfarslegri fjölbreytni, bæði í ritmáli (bókmáli og nýnorsku) og ekki hvað síst í talmáli, leiðir pað af sér að peir búa yfir miklu meiri óvirkum málskilningi en flestir Danir og Svíar. Segja má að fyrir Norðmann sé pað að heyra dönsku eða sænsku ekki mikið öðruvísi en að skilja fjarlæga norska mállýsku - pað sé hvort sem er um að ræða tilbrigði við mál innan skandinavísku mállýskusamfellunnar. 


\section{Er skilningur á grannmálum í hættu?}

Enn pá er sennilegt að Skandinavar notist við grannmálin í samskiptum sínum pegar peir hittast. En útlit er fyrir, að pað verði aðeins hlutskipti Norðmanna að geta átt samskipti við fólk frá báðum nágrannalöndunum á móðurmáli sínu. Á norrænu tungumálapingi árið 2000 setti danski prófessorinn Jørn Lund fram pennan ógnvænlega vitnisburð um hvernig staðan er núna:

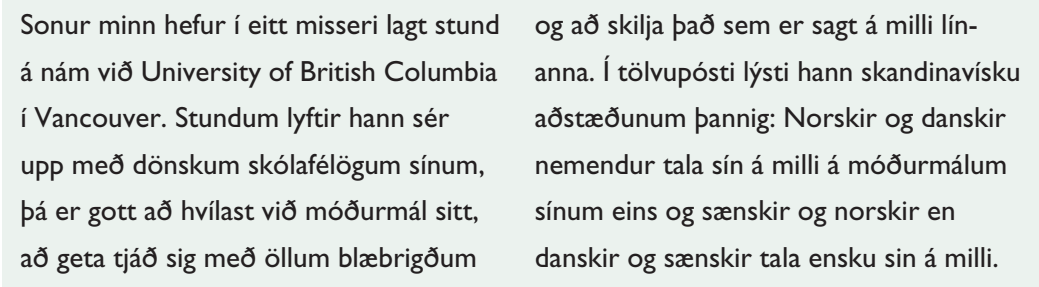

Aðstaða, eins og sú sem prófessor Lund segir hér frá, getur að vísu komið upp pegar Skandinavar hittast í enskumælandi umhverfi utan Norðurlanda. En pað er margt sem bendir til pess að petta sama eigi sér stað pegar ungir Skandinavar frá mismunandi löndum hittast $i$ Skandinaviu.

Ef enska yrði ríkjandi sem „,ingua“ franca í munnlegum samskiptum milli Skandinava myndi afar mikilvægur páttur norrænu sjálfsmyndarinnar hverfa. Og pá væri ekki lengur, í fyrsta skipti í tvö púsund ár, hægt að skynja norræna málsvæðið í Skandinavíu sem eina mállýskuheild, heldur myndu málin greinast hvert frá öðru í mismunandi fjarlægðarmál.

Frá norrænu sjónarhorni séð hlýtur slík framtíðarsýn nánast að teljast menningarlegt stórslys en til allrar hamingju er ekki ástæða til að gera ráð fyrir pví nú. Dað eru eins og áður hefur komið fram, hins vegar uppi ákveðin teikn um að svo gæti farið ef Skandinavar skilja ekki verðmæti pess að eiga samskipti við yfir 20 milljónir manna á eigin tungumáli - ef til vill með ákveðinni aðlögun í orðaforða og framburði ef maður tekur eftir að viðmælandinn skilur ekki hvert orð. Með gagnkvæmri virðingu og áhuga fyrir pví sem er líkt og ólíkt með tungumálunum ætti okkur að vera kleift að varðveita Skandinavíu sem eina mál- og menningarheild um leið og hægt er að fagna ákveðnum fjölbreytileika. Detta mun ef til 
vill gera okkur opnari og losa okkur við fordóma í garð pess nýja fjölmenningarlega umhverfis sem blasir við okkur í nútímasamfélagi.

Dýđing úr norsku á islensku: Sigrún Kristín Magnúsdóttir

\section{Ritaskrá}

Bandle, Oskar (ritstj.) (2002): The Nordic Languages. Volume 1. Berlín - New York. (Stórt vísindalegt uppsláttarrit í tveimur bindum; von er á öđru bindi árið 2005) Braunmüller, Kurt (1998): De nordiske språk. Osló. (Kennslubók; upphaflega skrifuð á býsku fyrir pýska nemendur í norrænum málum)

Haugen, Einar (1976): The Scandinavian Languages. An introduction to their history. London. (Vísindalegt yfirlitsverk)
Karker, Allan, Birgitta Lingren \& Ståle Løland ( ritstj.) (1997): Nordens språk. Osló. (Frekar auðskilið yfirlitsverk) Torp, Arne (1998): Nordiske språk i nordisk og germansk perspektiv. Osló. (Kennslubók, rituð fyrir nemendur í norsku á háskólastigi sem höfðu norsku sem móðurmál. Einn kafla bókarinnar er að finna á slóðinni: http://vestnorden.no/vestnord.doc)

Wessén, Elias (1965): De nordiska språken. Stokkhólmi. (Kennslubók, rituð fyrir nemendur í norrænum málum)

\section{Vefslóðir}

Um norrænt tungu-

málasamstarf:

Um skandinavískan skilning á grannmálum:

Um ,Vestnorden“:

Um ,lingua franca“:

Um ,pomorverslunina“:

Um rússanorsku:

Um älvdölsku:

Um vesturjósku:

Um lágpýsku:

Um frísnesku:

Um suðurjósku: www.norden.org/sprak

www.nordkontakt.nu

vestnorden.no

www.uwm.edu/ corre/franca/edition2/lingua.2.html. www.pomor.no www.kortlandt.nl/publications/art197e.pdf. swedia.ling.umu.se/Svealand/Dalarna/Alvdalen www.statsbiblioteket.dk/dlh www.lowlands-l.net www.rostra.dk/platt www.lowlands-l.net www.dialekt.dk www.jyskordbog.dk 


\section{KAISA HÄKKINEN}

\section{Finnska}

\section{Finnska og skyld mál}

Finnska telst til úrölsku málaættarinnar, grannrar og slitróttrar keðju mála sem teygir sig frá ströndum Eystrasalts alla leið að Jenisfljótinu og Tajmýrskaganum í Síberíu. Nafnið úrölsk mál hefur verið notað frá upphafi nítjándu aldar og byggist á pví að mörg pessara mála eru töluð í nágrenni Úralfjallanna á landamærum Asíu og Evrópu. Nú er talið að kjarnasvæðið hafi upprunalega verið í nágrenni Volgakröken eða á svæðinu sem kallað er Hvíta-Rússland.

Úrölsku málaættinni er venjulega skipt upp í tvær megingreinar. Austurgreininni tilheyra samójedísk mál, sem töluð eru í Síberíu, en málin á vesturgreininni teljast til hins svo kallaða finnsk-úgríska málaflokks. Hann samanstendur aftur af svokölluðum eystrasaltsfinnskum málum, að hluta til af úgrísku greininni, með ob-úgrísku málin mansi og chanti ásamt nánum ættingja peirra ungverskunni. Nú búa Ungverjar fjarri öllum tungumálaættingjum vegna pess að forfeður peirra fluttu til Mið-Evrópu ásamt tyrkneskum ættingjum undir lok tíundu aldar eftir Krist. Aðrar finnsk-úgrískar málaættir eru samísk mál, volgafinnsku málin mordvinska og mari og permísku málin komi og udmúrtíska.

Auk finnskunnar tilheyra eystrasaltsfinnsku málunum karelska, vepsíska, votíska, estníska og livíska. Pessi mál eiga margt sameiginlegt bæði hvað varðar málfræðilega gerð og orðaforða, jafnvel pótt málin séu ekki gagnkvæmt skiljanleg eins og skandinavísku málin. Skyldleikinn byggist fyrst og fremst á langri sameiginlegri sögu. Úrölsku málin í kringum Eystrasaltið hafa myndað heild, hina svokölluðu fornfinnsku, en frá pví máli hafa tungumálin, sem töluð eru $i$ dag, próast. Eldri grein fornfinnsku er fornsamíska en af yngri greininni er sameiginlegt frummál eystrasaltsfinnsku málanna, fornfinnska. Mikilvægustu eiginleikarnir í formgerð finnskunnar hafa orðið til á tímun sameiginlegrar eystrasaltsfinnsku. 


\section{Forsaga Finna}

Fólkið, sem byggt hefur Finnland, hefur komið úr mörgum áttum og í tímanna rás talað mörg ólík mál. Engin leið er til pess að komast að pví með nokkurri vissu hvenær fyrstu mennirnir, sem töluðu mál af úrölsku málaættinni, komu til Finnlands eða hvort peir voru meðal frumbyggjanna í Finnlandi. Um pað bil prjú púsund árum fyrir Krist er talið að tungumálið í núverandi Finnlandi hafi verið einhvers konar frum-fornfinnska vegna pess að pá taldist Finnland til kamkeramíska menningarsvæðisins sem samkvæmt hefðinni hefur verið talið til úralska tungumálasvæðisins.

Á svæðunum í kringum Eystrasalt hafa forfeður Finna átt nágranna af indóevrópsku bergi brotna sem síðar greindust í Balta og Germana. Greinilega má sjá af mismunandi tökuorðum að samskipti hafa átt sér stað á milli pessara hópa. Eldri tökuorð úr baltnesku eru t. d. halla frost, heinä hey og ohra korn, og germönsk tökuorð eru t.d. kaura hafrar, pelto akur (sbr. engi) og ruis rúgur. Af tökuorðunum má sjá að hinir fornu Finnar, sem til pessa höfðu lifað af veiðum, lærðu dýraeldi og að yrkja jörðina af hinum baltísku og germönsku nágrönnum sínum. Sú staðreynd, að tökuorðin eru hin sömu í öllum eystrasaltsfinnsku málunum, sýnir að pau hafa verið tekin inn í málið áður en finnskan próaðist í sérmál.

\section{Finnskar mállýskur}

Finnskum mállýskum er skipt í tvo meginflokka, austurfinnskar og vesturfinnskar mállýskur. Landamærin á milli peirra fylgja að mestu leyti ríkislandamærunum sem urðu til á milli Svípjóðar og Rússlands pegar samið var um frið í Nöteborg 1323. Degar sættir náðust varð Finnland opinberlega hluti sænska ríkisins. Mismunurinn á milli vesturfinnsku og austurfinnsku mállýsknanna á rætur sínar greinilega að rekja miklu lengra aftur, alveg aftur til forsögulegs tíma.

Á steinöld bjuggu varla meira en nokkur púsund manns á svæðinu sem nú telst Finnland og svo fámenn pjóð gat ekki dreifst jafnt um allt landið. Fólkið lifði af dýra- og fiskveiðum auk tínslu og leitaði 
að nýjum stöðum par sem æti var að finna til pess að búa á. Föst búseta tíðkaðist ekki fyrr en undir lok steinaldar pegar fólk fór að halda húsdýr og yrkja jörðina. Bestu svæðin fyrir nýju atvinnuvegina voru í Vestur-Finnlandi, Satakunta, Tavastland (Häme á finnsku) og Suðvestur-Finnlandi (hið eiginlega Finnland, fi. Varsinais-Suomi), í Austur-Karelíu (Kirjálalandi). Par af leiðandi mynduðust smám saman prjú aðalmállýskusvæði: Finnland, Tavastland og Karelía.

Bæði finnska nafnið Suomi og sænska nafnið Finnland hafa frá upphafi aðeins náð yfir suðvesturhluta landsins sem frá árinu 1800 hefur til aðgreiningar verið nefnt Hið eiginlega Finnland. Suðvesturfinnsku og tavastlensku mállýskurnar eiga, að minnsta kosti að hluta til, rætur að rekja til sama máls og eru dæmi um elsta lag vesturfinnsku mállýsknanna. Frá peim hafa síðan mállýskurnar í Austurbotni próast um leið og föst búseta breiddist út um Austurbotn. Mállýskurnar í norðurhlutanum eru blandaðri vegna pess að hluti fólksins par var frá Austur-Finnlandi. Dar sem engin landamæri voru til á milli Finnlands og Svípjóðar fyrr á tímum flutti finnskt fólk einnig út í Tornedal og Vesturbotn sem nú tilheyra Svípjóð. Tornedalfinnska mállýskan hefur síðar, vegna samskipta við sænskumælandi fólk, próast í pá mállýsku sem nú er kölluð meänkieli („,málið okkar“) mál sem er viðurkennt sem minnihlutamállýska í Svípjóð. Austurfinnsku mállýskurnar eiga rætur sínar að mestu að rekja til fornkarelsku prátt fyrir að savolaxísku mállýskurnar beri ýmis merki áhrifa frá vestri.

Skipting í mállýskur hefur átt sér stað á meðan flestir í Finnlandi lifðu á landbúnaði og bjuggu og unnu á sama stað allt sitt líf. Dær aðstæður tóku verulegum breytingum á síðari hluta nítjándu aldar. Dá voru lagðar járnbrautir, byggð stór iðnaðarver og fólk fékk störf sem verkamenn og fluttist á milli staða í leit að vinnu. Á tuttugustu öld hafa skilin á milli mállýskna orðið skarpari í takt við aukna fólksflutninga. Á meðan síðari heimsstyrjöldin geisaði voru 400.000 manns fluttir frá Karelíu til annarra hluta Finnlands. Á sjöunda og áttunda áratugnum hófust aðrir fólksflutningar pegar fólk flutti af landsbyggðinni í borgirnar. Frá Savolax og Austurbotni fluttu sérstaklega margir til svæðisins í kringum Helsinki. Í Helsinki voru eiginlega allir íbúarnir sænskumælandi á síðari hluta nítjándu aldar 


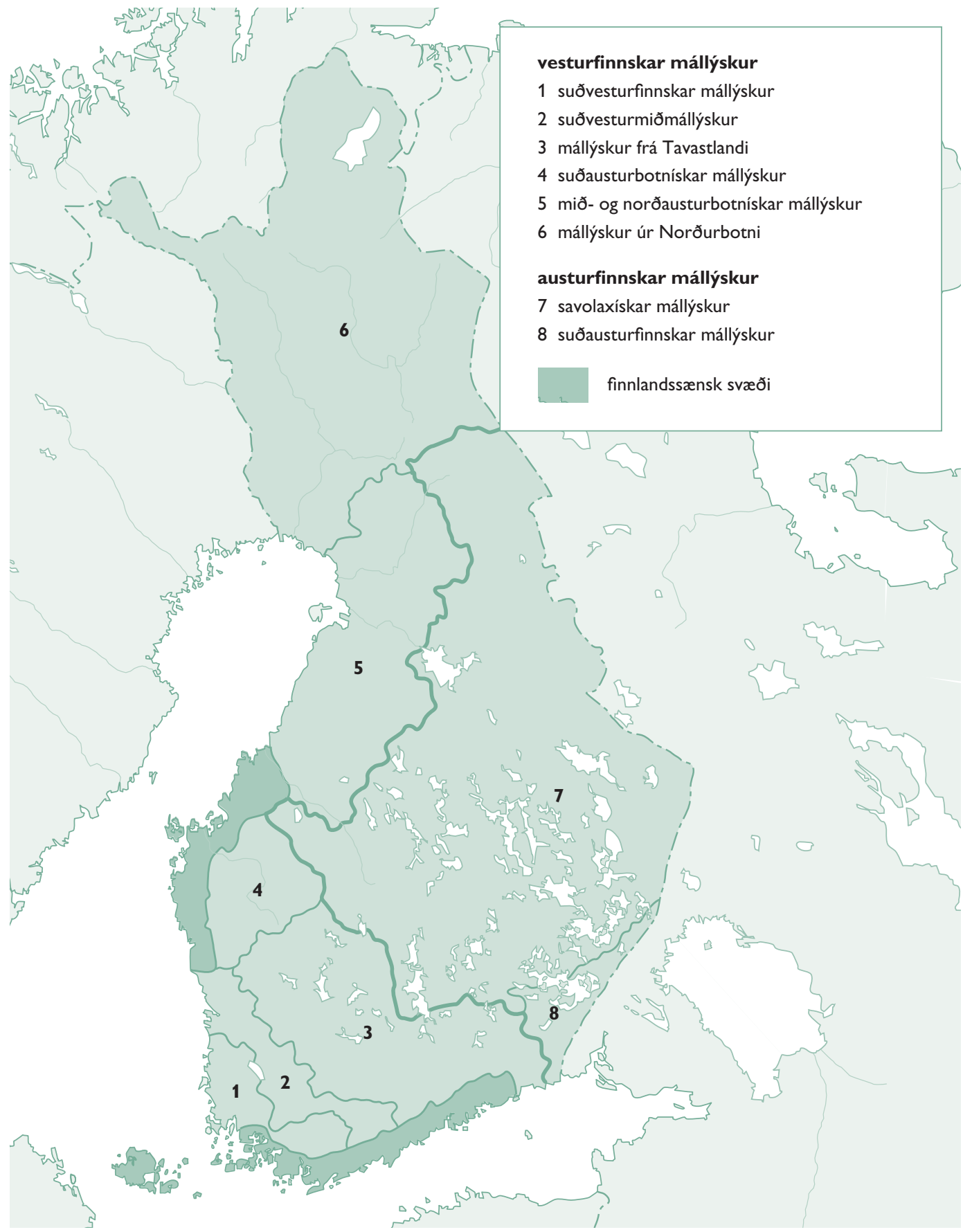


en á tuttugustu öld er borgin orðin fjölmennasta og einnig fjölbreyttasta finnska mállýskusvæðið. Á sama tíma fluttu einnig margir frá Finnlandi til Svípjóðar. Deir sem fluttu hafa hætt að nota séreinkenni mállýsknanna frá heimkynnum sínum og gömlu sóknarmállýskurnar viku í æríkara mæli fyrir almennu finnsku talmáli.

\section{Tímabil í sögu finnsku}

\section{Fornfinnska og miðaldafinnska}

Skipta má próunarsögu finnsku frá frumfinnsku í fimm hluta. Elsta tímabilið er tímabil fornfinnskunnar á fyrstu púsund árum okkar tímatals. Degar á peim tíma var grundvöllurinn fyrir skiptingu mállýsknanna lagður. Næsta tímabil, sem er mikilvægt menningarsögulega, var tímabil miðaldafinnskunnar. Miðaldir í Finnlandi teljast frá pví um 1150 en frá peim tíma eru elstu sögulegar heimildir um Finna. Á miðöldum varð Finnland hluti af sænska ríkinu og par giltu sænsk lög og stjórnarhættir voru sænskir. Opinberlega skipaði finnskan engan sess en hagstætt pótti pó að nota hana við vissar kringumstæður. Af peim sökum fékk finnskan mörg orð og orðatiltæki, sem varða lög og stjórnun, að láni úr sænsku eins og t.d. laamanni lögmaður, laki lög og tuomari dómari.

Á miðöldum var heiðnum Finnum snúið til kristni bæði að vestan og austan. Sá hluti Finnlands, sem féll undir veldi Svía, tilheyrði rómversk-katólsku kirkjunni en kenningar rétttrúnaðarkirkjunnar urðu útbreiddar í Karelíu. Útbreiðsla kristninnar hafði mikil áhrif á heimsmynd Finna og orðaforða í finnsku. Innan kirkjunnar voru viss embætti og menntakerfi og nú bauðst Finnum einnig að ganga menntaveginn. Aðalfagið var latína, sameiginlegt tungumál kirkjunnar og háskólanna á miðöldum. Flest orð, sem nauðsynleg voru í kirkjustarfinu, komu úr sænsku eins og t.d. enkeli engill, kirkko kirkja og messu messa en sum peirra komu beint úr latínu, t.d. epistola pistill, mammona Mammon og saatana Satan. 


\section{Gamla ritfinnskan}

Priðja tímabil próunarinnar, tími gömlu ritfinnskunnar, hófst í kringum 1540 pegar siðaskiptin urðu í Finnlandi. Siðaskiptunum fylgdi að fólkið átti að njóta guðsorðs á móðurmálinu og ef ritmál var ekki til pá varð að búa pað til. Mikael Agricola, sem seinna varð biskup í Turku (Åbo), pýddi og lét prenta fyrstu bækurnar á finnsku. Mikilvægust peirra var Nýja testamentið sem kom út árið 1548. Agricola notaði mállýskurnar í grennd við Turku (Åbo) sem grunn að ritmáli vegna pess að Turku (Åbo) var höfuðborgin og miðstöð kirkjunnar. En hann notaðist einnig við aðrar mállýskur til pess að bæta tjáningarmöguleika Turku-mállýskunnar.

Biblían var öll pýdd á finnsku árið 1642 og var fyrirmynd að ritmáli alveg fram á nítjándu öld. Á peim tíma voru bókmenntirnar aðallega trúarlegs eðlis. Ritmálið varð fyrir áhrifum af austurbotnískum og tavastlenskum mállýskum en suðvesturfinnsku mállýskurnar mynduðu ennpá grunninn að pví.

\section{Eldri nútímafinnska}

Nýtt skeið í sögu finnskunnar, eldri nútímafinnska, hófst á nítjándu öld. Svípjóð tapaði Finnlandi til Rússa árið 1809 og Finnland varð stórfurstadæmi með sjálfstjórn undir Rússlandi. Sænska var áfram viðskiptamálið en kröfurnar um, að staða finnskunnar styrktist, urðu markvissari. Viðhorf gagnvart málinu voru allt önnur en áður. Álitið var að mállýskurnar í Vestur-Finnlandi hefðu skemmst vegna mikilla áhrifa frá sænsku og munstur fyrir ritmálið var sótt í hinar „hreinni“ austurmállýskur. Vinsældir austurmállýsknanna jukust einnig með sagnaskáldskapnum Kalevala (1835) sem Elias Lönnrot hafði tekið saman úr skáldskap er hann hafði að mestu safnað saman í Karelíu. Markvisst var hafist handa við að próa finnsku sem menningarmál með pví að gefa út blöð, kennslubækur, fagbækur á mismunandi sviðum og fagurbókmenntir auk pess að búa til ný orð (sbr. kaflann um orðaforða). 
Prátt fyrir að finnskan hafi próast mikið á nítjándu öld var pað ekki fyrr en á síðari hluta aldarinnar sem hún öðlaðist opinbera stöðu. Alexander keisari II. gaf árið 1863 út fyrirskipun um að finnska ætti að standa jafnfætis sænsku ,í öllu pví sem beinlínis viðkemur finnsku íbúunum". Fyrsti finnskumælandi framhaldsskólinn var stofnaður í Jyväskylä árið 1858 og starfræksla finnska grunnskólans hófst árið 1866. •að er finnska skólakerfinu að pakka að fleiri finnskir stúdentar sóttu inn í háskólann og pannig menntuðust fleiri embættismenn með finnsku að móðurmáli. Degar á nítjándu öld var próun finnsku og samfélagslegrar stöðu hennar svo hröð að hægt var að nota finnsku við næstum pví allar aðstæður og á öllum stigum daglegs lífs. Auðvitað voru til undantekningar. Til dæmis var sænska notuð á æðstu stigum réttarkerfisins allt fram á tuttugustu öld og við háskólann í Helsinki, eina háskólinn í landinu fram á tuttugustu öld, hélt sænskan stöðu sinni sem aðalmálið í rannsóknum og kennslu fram undir fjórða áratug síðustu aldar.

\section{Nútímafinnska}

Fimmta próunarskeið finnskunnar, nútímafinnsku, telst vera frá pví um 1880. Eftir pað hafa ekki orðið neinar mikilvægar breytingar á byggingu finnsku, próunin hefur verið í hægum takti samhliða breytingum í umheiminum. En aftur á móti hefur málnotkunin og viðhorf til hennar breyst afar mikið. Undir lok nítjándu aldar og í upphafi peirrar tuttugustu átti menntað fólk að tala eftir lögmálum ritmálsins við allar aðstæður. Í dag er viðhorfið annað. Við formlegar aðstæður er enn talað staðalmál en við önnur tækifæri er tiltækt talmál notað eða hreinlega mállýskur. Svipaðar tilhneigingar eru í ritmálinu. Í fagurbókmenntum má til dæmis oft finna innskot hversdagslegs talmáls og slangurs.

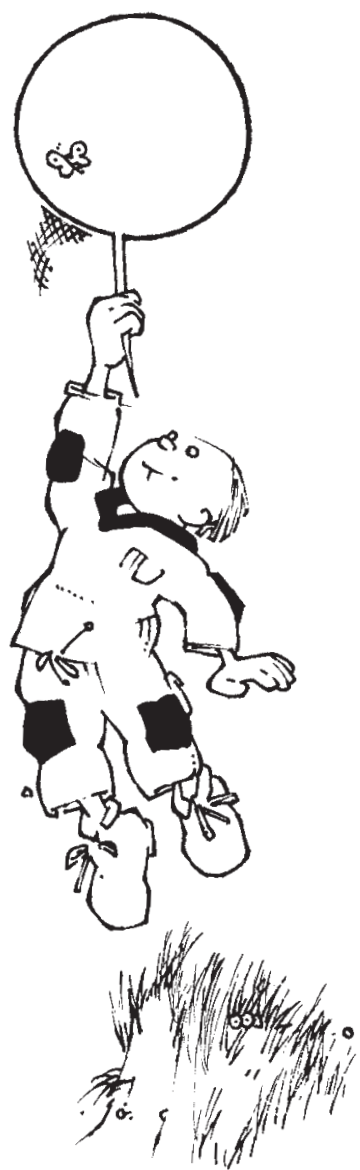




\section{Hljóðkerfi nútímafinnsku}

Hljóðkerfi finnsku einkennist af fjölbreyttum sérhljóðum og tiltölulega fáum samhljóðum. Sérhljóðar eru átta og hægt er að skipta peim í prjá flokka eftir pví hvernig peir tengjast öðrum:

\begin{tabular}{ll}
\hline fremri sérhljóðar & $y$, ä, ö \\
\hline hlutlausir sérhljóđar & e, i \\
\hline aftari sérhljóðar & $a$, o, u \\
\hline
\end{tabular}

Að nýrri tökuorðum og samsettum orðum undanteknum geta finnsk orð ekki verið samsett bæði úr fremri og aftari sérhljóðum. Fremri og aftari sérhljóðar geta aðeins tengst sín á milli eða við hlutlausa sérhljóða (sem hljóðfræðilega séð eru fremri sérhljóðar): talo hús, pyhä heilagur, leima stimpill, seinä veggur. Dessi regla um tengingu er kölluð sérhljóðasamræmi. Orð af erlendum uppruna, sem brjóta í bága við sérhljóðasamræmið, eru oft borin ranglega fram af Finnum í samræmi við reglur sérhljóðasamræmisins. Til dæmis er olympia borið fram eins og ólumppía.

Í orðum, sem eru að uppruna finnsk, eru aðeins 13 samhljóðar en vegna áhrifa nýrri tökuorða hefur samhljóðakerfið orðið umfangsmeira. Í töflunni hér á eftir eru samhljóðar af framandi uppruna (b, f, š, g) skáletraðir:

\begin{tabular}{llll}
\hline lokhljóð & $\mathrm{p}, \mathrm{b}$ & $\mathrm{t}, \mathrm{d}$ & $\mathrm{k}, \mathrm{g}$ \\
\hline önghljóð & $\mathrm{f}$ & $\mathrm{s}, \breve{s}$ & $\mathrm{~h}$ \\
\hline hálfsérhljóð & $\mathrm{v}$ & & $\mathrm{j}$ \\
\hline sveifluhljóð & $\mathrm{l}, \mathrm{r}$ & & \\
\hline nefhljóð & $\mathrm{m}$ & $\mathrm{n}$ & $\eta$ \\
\hline
\end{tabular}


prátt fyrir að finnska sé samkvæmt grundvallarreglum rituð eins og hún er borin fram samsvara hljóðin í málinu bókstöfunum ekki algerlega. Í finnska stafrófinu eru líka nokkrir erlendir bókstafir ( $c, q$, $w, x, z, \stackrel{a}{)})$ sem eru aðeins notaðir til pess að skrifa nöfn og orð úr erlendum tungumálum. Par fyrir utan á $\mathrm{y}$-hljóðið engan sérstakan bókstaf en er skrifað eins og $n$ í öðrum tungumálum (t.d. lanka [layka]) eða $n g$ (kangas [kaynas]).

Næstum öll hljóð í finnsku geta bæði verið stutt og löng. Eina undantekningin eru samhljóðarnir $d, v, j$ og $h$. Í mállýskum geta $v, j$ og $h$ líka verið borin fram eins og pau séu löng og $d$ er hvergi að finna í upprunalegum mállýskum. Hvernig pað hefur komið inn í ritmálið verður útskýrt stuttlega hér á eftir.

Lengd eða gildi hljóða í finnsku hefur grundvallaráhrif á pýðingu orða. Gildið fer ekki eftir áherslum eða gerð atkvæða heldur er pað sjálfstæður eiginleiki sem taka parf nákvæmt tillit til bæði í ritun og framburði. Aðaláherslan er alltaf á fyrsta atkvæðið í finnskum orðum. Svíi, sem fer að læra finnsku, mun að öllum líkindum gera villur bæði í framburði og ritun sem varða einmitt gildið. Hér á eftir er dæmi um áhrif gildis á merkingu:

\begin{tabular}{ll}
\hline tule & komdu \\
\hline tulee & kemur \\
\hline (ei) tuule & blæs (ekki) \\
\hline tuulee & blæs \\
\hline tullee & kemur sennilega \\
\hline tuullee & blæs sennilega \\
\hline kansa & fólk \\
\hline kanssa & ásamt \\
\hline
\end{tabular}


Finnsk orð eru að meðaltali með u.p.b. jafn marga sérhljóða og samhljóða. Kjarni atkvæðanna er myndaður af sérhljóða eða tvíhljóða, p.e.a.s. samsetningu tveggja sérhljóða. Allir sérhljóðar geta myndað tvíhljóða með $i$ (ai, ei, oi, ui, yi, äi, öi) og samkvæmt reglum sérhljóðasamræmisins einnig með u eða y (au, eu, iu, ou, ey, iy, äy, öy). Dar fyrir utan eru prír svokallaðir stígandi sérhljóðar: ie, uo, yö. Deir hafa orðið til úr löngum sérhljóðum $\left({ }^{\star} e e,{ }^{\star} o o,{ }^{\star} \ddot{o} 0 \ddot{)}\right.$ og sögulegur bakgrunnur peirra kemur í ljós af hljóðvíxlum við beygingu orða: tie vegur : teissä, suo mýri : soissa, työ vinna: töissä.

Í finnskum orðum eru tíu mismunandi tegundir af atkvæðum: $\mathrm{KV}, \mathrm{KVV}, \mathrm{KVK}, \mathrm{KVVK}, \mathrm{KVKK}, \mathrm{V}, \mathrm{VK}, \mathrm{VV}, \mathrm{VVK}, \mathrm{VKK}(\mathrm{K}=\mathrm{sam}-$ hljóði, $\mathrm{V}$ = sérhljóði). Algengustu tegundirnar eru KV og KVK. Gamlir finnskir orðstofnar eru oft tveggja atkvæða og enda á sérhljóða. Ka-la fiskur og jal-ka fótur eru dæmi um frummyndir finnskúgrískra orðstofna. Eins og fram kemur í listanum yfir tegundir atkvæða getur finnskt atkvæði ekki byrjað á fleiri en einum samhljóða og orð getur heldur ekki endað á nema einum samhljóða (sbr. ranta strönd). Einföld grunnregla er að skipting í atkvæði er á milli hverrar samsetningar samhljóða og sérhljóða (-KV), t.d. pos-ki kinn og pis-tää stinga. Skiptingin getur líka verið á milli sérhljóða eins og t.d. sa-no-a segja og mä-en (eignarfall af mäki brekka).

\section{Formkerfisleg grundvallareinkenni}

Formkerfi (beygingarkerfi) finnsku skiptist í tvo hluta, orðbeygingu og afleiddar orðmyndanir. Með afleiðslu eru ný orð mynduð og með beygingum eru núverandi orð felld að hlutverki sínu í setningunni. Bæði viðskeyti og beyging verða til með pví að endingu er bætt við stofn orðsins. Aftur verður vikið að afleiðslu í kaflanum um orðaforða. Einkenni allra úralskra mála er mikill fjöldi beygingarmynda. Við beygingu fallorða (nafnorða, lýsingarorða o.s.frv.) eru viðskeyti notuð til pess að gefa til kynna bæði tölu og mismunandi sambönd. Í finnska ritmálinu eru 15 mismunandi fallmyndir: 


\begin{tabular}{lll}
\hline & eintala & fleirtala \\
\hline nefnifall & jalka, fótur & jalat, fætur \\
\hline eignarfall & jalan & jalkojen \\
\hline polfall & jalan & jalat \\
\hline deilifall & jalkaa & jalkoja \\
\hline essivus & jalkana, eins og fótur & jalkoina \\
\hline translativus & jalaksi, í fót & jaloiksi \\
\hline inessivus & jalassa, í fætinum & jaloissa \\
\hline elativus & jalasta, úr fætinum & jaloista \\
\hline illativus & jalkaan, inn í fótinn & jalkoihin \\
\hline adessivus & jalalla, á fætinum & jaloilla \\
\hline sviptifall & jalalta, af fætinum & jaloilta \\
\hline allativus & jalalle, á fætinum & jaloille \\
\hline abessivus & jalatta, án fótar & jaloitta \\
\hline komitativus & jalkoineen, með eigin fæti & jalkoineen \\
\hline instruktivus & jalan, fótgangandi & jaloin \\
\hline Pýðingarnar eru ónákvæmar & \\
\hline
\end{tabular}

Dar sem beygingarviðskeytin verða að fylgja reglum sérhljóðasamræmis hafa mörg viðskeyti eina mynd með fremri og aðra mynd með aftari sérhljóðum t.d. talo-ssa í húsinu - kylä-ssä í bænum, kissa-lta af kettinum - hiire-ltä af músinni.

Með hjálp endinga er einnig hægt að gera grein fyrir eignarhaldi. Í finnsku eru, eins og í skandinavísku málunum, sex málfræðilegarpersónur og hver peirra á sitt eigið svo kallaða eignarviðskeyti:

\begin{tabular}{llll}
\hline eintala & & fleirtala & \\
\hline kissa-ni & minn köttur & kissa-mme & okkar köttur \\
\hline kissa-si & pinn köttur & kissa-nne & ykkar köttur \\
\hline (hänen) kissa-nsa & hans/hennar köttur & (heidän) kissa-nsa & peirra köttur \\
\hline
\end{tabular}


Fleirtöluendingar, fallendingar og eignarendingar má nota samtímis en peim verður að skeyta við stofn orðsins í ákveðinni röð: Fyrst er fleirtöluendingin, svo fallendingin og að endingu eignarviðskeytið:

\begin{tabular}{ll}
\hline kissa-lle-mme & 'kattar-til-okkar' = til okkar kattar \\
\hline kisso-i-lle-nne & 'katt-a-til-ykkar' = til ykkar katta
\end{tabular}

Í finnsku eru engir greinar og heldur ekkert málfræðilegt kyn. Hér er einnig um að ræða séreinkenni úralskra mála. Đá eru heldur ekki til nein sérstök fornöfn fyrir karlkyn eða kvenkyn. Finnska fornafnið hän á við um bæði hann og hana í íslensku.

Í beygingu sagna er hægt með endingum að greina á milli germyndar og polmyndar, mismunandi hátta, tíða og persóna. Polmyndin er eins konar óákveðin persónumynd, svarar til óákveðinnar polmyndar í íslensku. Dolmyndin hefur sérendingu og par að auki eigin persónuendingu, til dæmis:

\begin{tabular}{lll}
\hline germynd & (hän) sanoo, (hän) sanoi & hann segir/sagði \\
\hline polmynd & sano-ta-an, sano-tt-i-in & sagt er, sagt var \\
\hline
\end{tabular}

Germynd hefur enga sérstaka endingu og hefðbundin beyging germyndar í nútíð er aðeins með mismunandi endingar eftir persónu:

\begin{tabular}{llll}
\hline minä sano-n & ég segi & me sano-mme & við segjum \\
\hline sinä sano-t & pú segir & te sano-tte & pið segið \\
\hline hän sano-o & hann/hún segir & he sano-vat & pau segja \\
\hline
\end{tabular}

Í finnsku eru fjórir hættir:

\begin{tabular}{lll}
\hline framsöguháttur & sinä sanot & pú segir \\
\hline háttur sem táknar möguleika & sinä sanonet & pú segir sennilega \\
\hline skilyrðisháttur & sinä sanoisit & pú ættir að segja \\
\hline boðháttur & sano! & segðu! \\
\hline
\end{tabular}


Tíðarmyndirnar eru einnig fjórar:

\begin{tabular}{lll}
\hline nútíð & sinä sanot & pú segir \\
\hline pátið & sinä sanoit & pú sagðir \\
\hline núliðin tið & sinä olet sanonut & pú hefur sagt \\
\hline páliðin tíð & sinä olit sanonut & pú hafðir sagt \\
\hline
\end{tabular}

Eins og til dæmis í sænsku hafa sagnir í finnsku enga framtíðarmynd heldur er nútíð notuð til pess að tákna pað sem er að gerast og pað sem mun gerast í framtíðinni. Framtíð er táknuð með sögninni tulla munu: sinä tulet sanomaan pú munt segja.

Til hliðar við persónuendingarnar í persónuhætti eru sagnirnar einnig í nafnháttarmyndum. Dær skiptast í tvo megin flokka, nafnhætti og lýsingarhætti. Í finnsku eru fjórir nafnhættir. Mikilvægastur peirra er sá fyrsti, stutt mynd nafnháttar sem er stofn sagnarinnar og er notaður sem uppflettiorð í orðabókum. Nafnháttarmyndir sagna geta beygst í föllum en aðeins ákveðin föll eru notuð:

\begin{tabular}{lll}
\hline 1. nafnháttur & sanoa, sanoakse(ni) & segja, til pess að segja \\
\hline 2. nafnháttur & sanoessa, sanottaessa, sanoen & segjandi \\
\hline 3. nafnháttur & $\begin{array}{l}\text { sanomalla, sanomassa, sanomasta, } \\
\text { sanomalla, sanomatta, sanoman, } \\
\text { sanottaman }\end{array}$ & \\
\hline 4. nafnháttur & sanominen, sanomista & segjandi, að segja \\
\hline
\end{tabular}

Fyrsta nafnhættinum í translativus (sanoakse[ni]) verður alltaf að fylgja eignarviðskeyti eftir persónu. Ákveðna nafnhætti er líka hægt að nota í polmynd (sanottaessa, sanottaman) en langflesta peirra aðeins í germynd. Nafnhættirnir eru notaðir á mismunandi vegu í setningum, m.a. sem hluti af keðjusögnum: minun täytyy sanoa, ég verð að segja, olin juuri sanomassa, ég var einmitt að segja (,,ég var einmitt segjandi“). 
Lýsingarhættirnir eru prír og peir fyrstu tveir geta bæði staðið í germynd og polmynd:

\begin{tabular}{lll}
\hline 1. lýsingarháttur & sanova, sanottava & segjandi \\
\hline 2. lýsingarháttur & sanonut, sanottu & sagt \\
\hline gerandlýsingarháttur & sanoma & sagt (af e-um) \\
\hline
\end{tabular}

Lýsingarhættir eru m.a. notaðir sem lýsingarorð, t.d. naurava tyttö hlæjandi stúlka, oppinut mies lærður maður, og í samsettum sagnmyndum, t.d. hän oli sanonut hann hafði sagt, se olkoon sanottu pað hlýtur að vera sagt. Gerandlýsingarháttur er notaður pegar ætlunin er að fram komi hver hefur gert eitthvað, t.d. isän rakentama talo húsið sem pabbi byggði, p.e. pað af pabba byggða hús; tämä talo on isän rakentama petta hús sem pabbi byggði.

Ævafornt séreinkenni úrölsku málanna er að orðið fyrir neitun er í raun og veru sögn en ekki óbeygjanlegt orð eins og t.d. sænska orðið inte, danska og norska ikke og íslenska orðið ekki. Neitunarsögnin beygist í öllum persónunum sex:

\begin{tabular}{ll}
\hline minä en sano & me emme sano \\
\hline sinä et sano & te ette sano \\
\hline hän ei sano & he eivät sano. \\
\hline
\end{tabular}

Neitunarsögnin beygist ekki á jafn fjölbreyttan hátt og venjulegar sagnir. Dátíð og háttur er táknaður með mismunandi myndum af aðalsögninni og, ef pörf er á, með hjálparsögninni olla vera, eiga.

\begin{tabular}{ll}
\hline sinä et sano & pú segir ekki \\
\hline sinä et sanonut & pú sagðir ekki \\
\hline sinä et ole sanonut & pú hefur ekki sagt \\
\hline sinä et ollut sanonut & pú hafðir ekki sagt \\
\hline sinä et sanoisi & pú áttir ekki að segja \\
\hline sinä et sanone & pú porðir ekki að segja \\
\hline älä sano! & segðu ekki! \\
\hline
\end{tabular}


Með pví að einfalda nokkuð má segja að beygingarendingar í finnsku séu eins og kubbar sem hægt er að raða saman hverjum á eftir öðrum í ákveðinni röð fyrir aftan stofn orðsins. Sannarlega er til mikill fjöldi mismunandi endinga en pað er auðvelt að finna pær og greina. Ástaða pess að stundum er erfitt að læra ákveðna pætti beygingarkerfisins er að stundum verða hljóðbreytingar pegar endingar eru settar aftan á stofn orða. Hljóðbreytingar eru vegna tilfærslu hljóða við ákveðnar hljóðfræðilegar aðstæður á fyrri skeiðum málsins.

Sérstaklega margar hljóðbreytingar verða vegna svokallaðra víxla í lengd og gildi hljóða. Dað hefur sérstaklega áhrifá lokhljóðin $p, t$ og $k$, sem í einstaka tilfellum höfðu ádur veikst og breyst í önghljóð. Síðar hefur gildi peirra breyst eða horfið alveg. Sem dæmi um víxl í lengd og gildi hljóða mætti nefna:

\begin{tabular}{llll}
\hline tupa : tuvan & skáli & kampa : kamman & greiða \\
\hline pata $:$ padan & pottur & ranta $:$ rannan & strönd \\
\hline sika $:$ sian & svin & kenkä : kengän & skór \\
\hline
\end{tabular}

Löngu lokhljóðin pp, tt, kk hafa einnig orðið fyrir víxlum í gildi og pað birtist sem stytting:

\begin{tabular}{ll}
\hline nappi : napin & hnappur \\
\hline tyttö : tytön & stúlka \\
\hline tukki : tukin & stafur \\
\hline
\end{tabular}

Í dæmunum kemur upphaflega ástæðan fyrir víxlunum í ljós: lokhljóðið á milli fyrsta og annars atkvæðis veikist pegar annað atkvæðið er pað síðasta, pað er að segja endar á samhljóða. Í nútímafinnsku eru víxlin ekki alltaf samkvæmt pessari reglu vegna pess að gerð orðanna hefur breyst á margan annan hátt.

Víxlin í lengd og gildi hljóða skýra einnig hvernig samhljóðinn d hefur orðið til. Upphaflega hefur ,,veikari“ hliðstæða $t$ verið mjúka önghljóðið $d$ (eins og íslenskt $ð$ og danski framburðurinn af $d$ í t.d. vid). Par sem önghljóðið var ekki táknað með eigin bókstaf var pað ritað sem $d$, sem síðar hefur verið borinn fram eins og áherslulokhljóðið $d$ eftir reglum úr öðrum málum. Í mállýskunum hefur a 
breyst öðruvísi. Í vesturfinnsku mállýskunum er samsvarandi hljóð r eða l (pata : paran eða palan, pottur) og í austurfinnsku mállýskunum hefur pað horfið (pata : paan).

\section{Aðalatriði setningafræðinnar}

Eins og í skandinavísku málunum er orðaröðin venjulega í finnsku frumlag - umsögn - andlag, t.d. poika heittää pallon, drengurinn kastar boltanum. Gagnstæett skandinavísku málunum heldur finnskan pessari orðaröð pótt setningin byrji á atvikslið: nyt poika heittää pallon nú drengurinn kastar boltanum, p.e.a.s. nú kastar drengurinn boltanum. Orðaröðin getur verið breytileg, svo sem pegar hún er notuð til pess að ná fram sérstökum áhrifum t.d. áherslum eða andstæðu: pallon heittää poika pýðir að pað er drengurinn en ekki stúlkan sem kastar boltanum (á íslensku er hægt að segja pað sama með polmynd Boltanum var kastað af drengnum). Orðaröðina má einnig nota til pess að tákna eitthvað ákveðið, p.e.a.s. að eitthvað sé pekkt (í finnsku er annars ekki skilið á milli ákveðinnar og óákveðinnar myndar og poika getur bæði verið drengur og drengurinn): poika istuu pöydällä drengurinn situr á borðinu pöydällä istuu poika á borðinu situr drengur $=$ pað situr drengur á borðinu.

Fyrir ákveðnar setningar eru sérstakar gerðir. Ein peirra sýnir eign: pojalla on pallo drengurinn á bolta (eiginlega hjá drengnum er bolti). Í pessari setningu er pað eignin, p.e.a.s. boltinn, sem er málfræðilegt frumlag en eigandinn er táknaður með atvikslið nafnorðs í fallinu adessivus.

Dvingun eða skylda er táknuð með sérstakri setningargerð. Til dæmis gæti setningin drengurinn verður að fara verið pojan täytyy mennä (orðrétt nokkurn veginn vegna pess að drengurinn verður að fara), pojan on mentävä eða á gamaldags hátt pojan on meneminen (tvær síðastnefndu merkja u.p.b. pað er skylda drengsins að fara). Frumlagið samsvarar í pessum gerðum setninga orði í eignarfalli.

Í kringum nafnhætti og lýsingarhætti sagnarinnar er hægt að mynde svo kallað setningarlíki sem að merkingu samsvarar aukasetningu. Með fallendingum og eignarviðskeytum er hægt að tákna tíð og persónu: t.d. tul-tu-a-ni (kom-inn-eftir-mín) sem merkir: eftir að ég var kominn. 
Setningaskipun finnsku er stýrt af ströngum reglum um samræmi og setningahlutarnir hafa áhrif hver á annars gerð. Samræmið er ævafornt einkenni úralskra mála. Samræmið á milli frumlags og umsagnar hefur í för með sér að tala umsagnarinnar og persónumynd er háð persónu frumlagsins.

Í nútímafinnsku er, eins og í hinum náskyldu eystrasaltsfinnsku tungumálum, fornafnseinkunn og lýsingarorðseinkunn í sömu tölu og falli og aðalorðið:

\begin{tabular}{ll}
\hline tämä pieni talo & petta litla hús \\
\hline tässä pienessä talossa & í pessu litla húsi \\
\hline tähän pieneen taloon & inn í petta litla hús o.s.frv. \\
\hline
\end{tabular}

Samsvarandi samræmi er milli töluorða og aðalorða: kolme pientä poikaa brír litlir drengir : kolmelle pienelle pojalle til priggja litlu drengjanna. Í pessari setningagerð er einstakt að aðalorðið er í eintölu á eftir töluorðinu prátt fyrir að um sé að ræða marga einstaklinga (sbr. näille pienille pojille til pessara litlu drengja).

Í indóevrópskum málum er samhengið á milli orða oft táknað með forsetningum. Í finnsku og skyldum málum hafa engar forsetningar verið til frá fornu fari en pess í stað hafa verið notaðar eftirsetningar og fallmyndir. Enn pann dag í dag eru margar eftirsetningar notaðar í finnsku, t.d. talon edessä fyrir framan húsið, talon takana fyrir aftan húsið, talon alla undir húsinu. Sumar eftirsetningar má einnig - eftir mynstri úr sænsku og öðrum erlendum málum - nota sem forsetningar: aidan yli eða yli aidan yfir girðinguna, läpi seinän eða seinän läpi gegnum vegginn.

\section{Orðaforði}

Orðum í finnsku má skipta í prjá meginflokka eftir gerð peirra: Einföld grunnorð eins og kala fiskur og pesä bú, afleidd orð eins og kalastaa fiska og pesiä byggja bú og samsett orð eins og kalakauppa fiskbúð og linnunpesä fuglshreiður. Einföld grunnorð mynda stofninn í orðaforðanum og hluti peirra er af ævafornum úrölskum 
uppruna. T.d. hafa kala og pesä verið til allt frá tímum úralska fornmálsins og pau hafa varðveist óbreytt í allar pær púsundir ára sem liðnar eru frá tímum pess.

Ný orð eru oftast mynduð með viðskeytum, samsetningum eða pá að pau eru fengin að láni úr öðrum málum. Allar pessar aðferðir hafa verið notaðar eins lengi og hægt er að rekja próun orðaforðans í finnsku. Ný nafnorð hafa fyrst og fremst verið mynduð með samsetningum en viðskeyti hafa verið notuð til pess að búa til orð 1 öllum orðflokkum. Með viðskeytum er hægt að skipta um orðflokk og mynda sagnir úr nafnorðum (käsi hönd $\rightarrow$ käsitellä meðhöndla, fást við) eða nafnorð úr sögnum (maksaa borga $\rightarrow$ maksu borgun). Á eftir sama stofni er hægt að raða mörgum viðskeytum (käsiteltäryys meðhöndlanleiki).

Sem dæmi um möguleikana á að mynda orð með viðskeytum má taka orðið kirja bók. Orðið hefur upprunalega pýtt tákn eða skreyting (samanber kirjava skrautleg í nútímafinnsku):

\begin{tabular}{ll|ll}
\hline & & & \\
kirja & bók & kirjoite & skrift, afrit \\
kirjanen & bæklingur, smárit & kirje & bréf \\
kirjailla & semja (sauma út) & kirjuri & skrifari \\
kirjailija & rithöfundur & kirjoitin & forritari \\
kirjailu & skrif (einnig útsaumur) & kirjoittautua & innritari \\
kirjasto & bókasafn & kirjoittautuminen & innritun \\
kirjoittaa & skrifa & kirjain & bókstafur \\
kirjoitus & skrift & kirjaimellinen & bókstaflega \\
kirjoituttaa & láta skrifa & kirjaimisto & stafróf \\
kirjoittaja & skrifari & kirjake & gerð \\
kirjoitella & (halda áfram að) skrifa & kirjasin & gerð, stíll \\
kirjoitelma & grein & kirjata & bókfæra, skrá \\
kirjoittelu & skrifandi, skrif & kirjaaja & skrásetjari \\
kirjallinen & skrifleg, bókmenntaleg & kirjaamo & skráningarstofa \\
kirjallisuus & bókmenntir & kirjaus & bókfærsla, \\
kirjelmä & tilskrif & & skráning \\
kirjelmöidä & fást við skriftir & kirjauttaa & láta bókfæra/skrá \\
kirjelmöinti & skriffinnska & & \\
& & & \\
\hline & & & \\
\hline & & \\
& & \\
& & \\
& & \\
& & \\
& &
\end{tabular}


Samsetningar geta verið langtum lengri í finnsku en í öðrum málum og pað eru engin takmörk fyrir pví hve margir liðir geta verið í samsettu orði. T.d. er kaksisataaviisikymmenvuotisjuhlakilpapurjehdus (orðrétt tvöhundruðogfimmtíuáraafmæliskeppnissigling) samsett úr átta orðum par af tveimur viðskeytum (vuotis-ára-, purjehdus sigling ) en önnur eru einföld grunnorð.

Af einföldum grunnorðum í finnsku er um pað bil helmingurinn upprunaleg úrölsk orð og helmingurinn tökuorð. Elstu tökuorðin voru af frumindóevrópskum toga og sum peirra frá indóevrópska frummálinu (mehiläinen býfluga, mesi hunang, nimi nafn, vesi vatn), önnur frá indóírönsku tungumálaættinni (jumala guð, orja præll, sata hundrað, vasara hamar). Af tökuorðunum má sjá að úralskt fólk hefur alltaf verið nágrannar pess indóevrópska sem samkvæmt áliti margra vísindamanna átti frumheimkynni sín á svæðunum fyrir norðan Svartahaf.

Í kringum Eystrasalt hafa á tímum frumfinnskunnar verið fengin að láni orð frá baltneskum málum (heinä hey, rata hjól) og frá germönskum málum (kuningas konungur, ruhtinas fursti, germ. druhtinaz, í skandinavísku drott, ísl. dróttinn, sairas sár, germ. sairaz, sbr. skandinavíska sår, ísl. sár, siima svipa, lína, sbr. ísl. sími).

Seinna hefur finnska tekið orð að láni úr rússnesku (pakana heiðingi, saapas stígvél ) og síðast en ekki síst úr sænsku. Finnska hefur í næstum tvö púsund ár verið til við hliðina á sænsku sem einnig hefur verið önnur pjóðtunga Finnlands. Рað hefur ekki síst haft áhrif á allt sem viðkemur atvinnulífinu, mat, klæðnaði, byggingum, menntun, samfélaginu og menningu og pess vegna eru mörg tökuorð varðandi pessi svið einnig úr sænsku. Reiknað er með að í finnsku séu að minnsta kosti 4.000 tökuorð úr sænsku en pað hefur ekki verið rannsakað til hlítar og sennilega er fjöldi peirra talsvert meiri. Dar fyrir utan er fjöldinn allur af svo kölluðum pýðingarlánum eins og t.d. puutarha trjágarður (puu = tré, tarha = garður, sbr. danska have, norska hage) og peruskoulu grunnskóli. Drátt fyrir að finnska og sænska séu alls ekki af sömu málaætt hafa samskipti málanna verið svo mikil á sögulegum tíma að hugtök pessara tveggja mála eiga meira sameiginlegt en hugtök margra mjög skyldra mála. - Sænskan hefur meira að segja fengið orð að láni úr finnsku eins og t.d. pojke piltur (finnska poika) og känga skór (finnska kenkä). 
Tökuorðin úr sænsku hafa aðlagast hljóðkerfi finnsku á mismunandi hátt. Samhljóðar í byrjun orðs eru einfaldari, rödduð lokhljóð orðin órödduð, langt $f$ orðið að $h v$ og sérhljóð hefur bæst við í enda orðs. Pannig hafa t.d. sænsku orðin dans, dragon, giraff, stolpe og strand orðið að tanssi, rakuuna, kirahvi, tolppa og ranta á finnsku.

Í finnsku er einnig mikill fjöldi alpjóðlegra tökuorða sem hægt er að finna í flestum evrópskum málum, t.d. filosofia, professori, skandaali. Oft er erfitt að ákveða úr hvaða málum pau eru fengin að láni en flest eldri tökuorðin eru fengin úr sænsku. Á nítjándu öld og síðar hefur verið reynt að komast hjá pví að taka orð að láni og frekar reynt að búa til eigin orð. Margar vísindagreinar eiga t.d. bæði alpjóðleg og finnsk heiti: juridiikka - oikeustiede (sbr. ísl. réttarvísindi), psykologia - sielutiede (orðrétt sálvísindi). Finnska orðið fyrir síma er puhelin ( puhua, tala). Á síðari tímum hefur andstaðan gegn tökuorðum ekki verið jafn mikil en ef góð finnsk orð eru í boði finna pau venjulega hljómgrunn (t.d. palvelin pjónn, sbr. palvella pjóna).

\section{Finnskan í dag og á morgun}

Núna er finnska töluð af um pað bil fimm milljónum manna og staða málsins er sterkari en nokkru sinni. Hægt er að nota finnsku við hvaða kringumstæður sem er, bæði óformlegar og formlegar. Degar Finnland gekk í Evrópusambandið varð finnskan líka eitt opinberra mála sambandsins. Í Svípjóð er finnska opinberlega viðurkennt minnihlutamál.

Ábyrgðin á varðveislu finnsku er opinberlega hjá Rannsóknarmiðstöð innlendra mála. Rannsóknarmiðstöðin svarar spurningum um málið, gefur meðmæli um málnotkun og sér um útgáfu handbóka, stórrar lýsandi bókar um finnska málfræði og hvers konar orðabóka um nútímafinnsku, eldri finnsku og finnskar mállýskur. Dá eru einnig til umfangsmikil orðasöfn. Í Svípjóð ber sænsk-finnska orðanefndin ábyrgð á varðveislu finnskunnar.

Nú á tímum er, ekki síst á Norðurlöndunum, rætt um aukna ógnun ýmissa mála eins og ensku við norræn mál. Í peirri samkeppni eru aðstæður ólíkar. Sterkast standa pau mál sem eru opinber mál 
landanna og pau mál sem eru notuð við kennslu í skólum og við háskóla. Finnskan uppfyllir öll pessi viðmið. Málið varðveitist aðeins ef peir sem pað tala nota pað og varðveita.

Dýđing úr finnsku á saensku: Mikael Reuter

Dýding úr scensku á islensku: Sigrún Kristín Magnúsdóttir

\section{Ritaskrá}

Ennen, Muinoin. Miten menneisyyttämme Höglander, Sari \& Vehkanen, Marjut: tutkitaan. (Ritstj.): Riho Grünthal. $\quad$ Finskan lättare än du tror. Helsinki:

Tietolipas 180. Helsinki: Suomalaisen

Kirjallisuuden Seura 2002.

Edita 2001.

Ikola, Osmo: Nykysuomen opas. Turun

Häkkinen, Kaisa: Agricolasta nykykieleen. yliopiston suomalaisen ja yleisen

Suomen kirjakielen historia. Helsinki: $\quad$ kielitieteen laitoksen julkaisuja 65.

WSOY 1994.

Turku 2001.

Häkkinen, Kaisa: Svenska och finska

Karlsson, Fred: Finsk grammatik.

- sida vid sida i tusen år.

Helsinki: Suomalaisen Kirjallisuuden

Seura 1978.

\section{Vefslóðir}

www.spraknamnden.se/sverigefinska.htm

virtual.finland.fi (Education \& Research - Language)

www.kotus.fi 



\section{Samísk mál}

\section{Samískar byggđir og samísk mál}

Landsvæðið, sem Samar búa á, Sápmi, nær frá austurströnd Kólaskagans, um Norður-Finnland, yfir strönd og miðbik Noregs og miðbik Svípjóðar allt niður að Jämtlandi og Idre (sbr. kortið hér á eftir). Sápmi er samsett af landfræðilega samfelldum svæðum par sem stundaðar hafa verið ýmsar ólíkar hefðbundnar atvinnugreinar, m.a. skot- og fiskveiði, hreindýrarækt og landbúnaður. Innan svæðisins eru töluð mörg samísk mál og mállýskur.

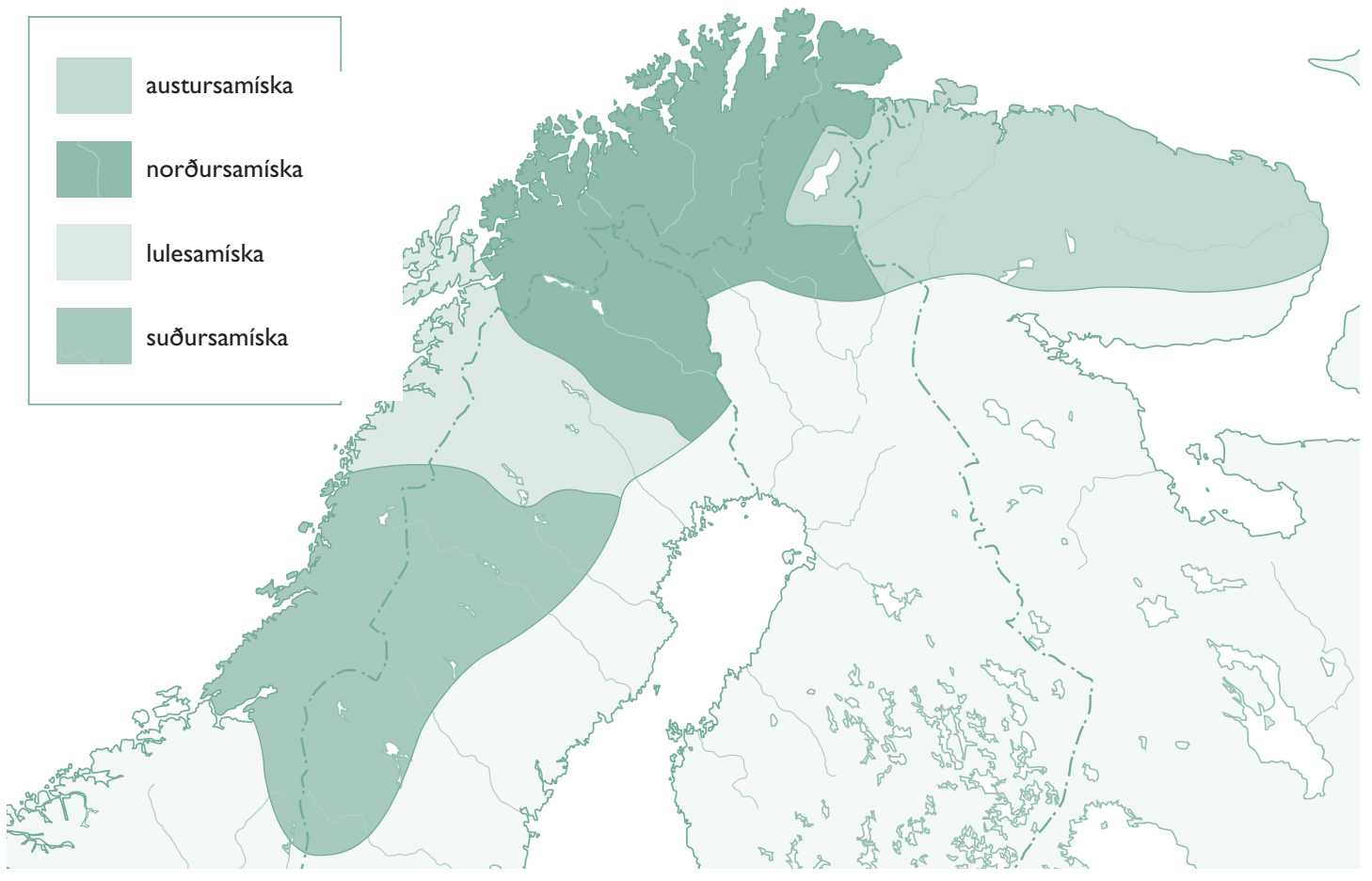

Mynd 1: Búsetusvæði Sama, Sápmi 
Samískum málum er venjulega skipt í prjú málsvæði: austursamísku, miðsamísku og suðursamísku. Dað er eftirtektarvert að markalínur samísks málsvæðis liggja aldrei samhliða landamærum.

Austursamísku málunum tilheyra enaresamiska, sem er töluð í Finnlandi umhverfis vatnið Enare träsk, og skoltsamiska sem töluð er bæði í Finnlandi og Rússlandi. Önnur mál, sem töluð eru á Kólaskaga, eru kildinsamiska, akkalasamiska og tersamiska.

Miđsamísku má skipta upp í norðursamísku og lulesamísku. Norðursamísku tilheyra sjávarsamíska, sem er töluðá strandsvæðum Noregs, finnmerkursamiska, sem er töluð í Finnmörku í Noregi (m.a. Kautokeino og Karasjokk) og nærliggjandi svæðum í Finnlandi (m.a. Utsjoki) og tornesamiska sem töluð er fyrir norðan Gällivare í Svípjóð og á nærliggjandi svæðum í Finnlandi og Noregi. Önnur miðsamísk mál eru lulesamiska, sem töluð er í Jokkmokk í Svípjóð og við Tysfjord í Noregi, og arjeplogssamiska sem er töluð á Arjeplogssvæðinu.

Til suðursamisku málanna heyra umesamiska, töluð í Vesturbotni, og hin eiginlega suðursamiska sem er töluð í Suður-Vesturbotni og á Jämtlandi.

\section{Söguleg samskipti}

Samar hafa búið á Sápmi í púsundir ára og höfðu lengi vel nær engin samskipti við annað fólk. Fyrstu samskiptin við skandinavískt fólk urðu ekki fyrr en fyrir rúmlega púsund árum en samskipti við annað finnskt-úgrískt fólk, p.e.a.s. fólk sem talaði skyld mál, hafa átt sér stað mörgum púsundum ára áður en farið var að ræða um Sama sem pjóðflokk.

Tungumál bera með sér upplýsingar um hið forna, um fólkið sem talaði málið, um pað við hvaða kjör pað bjó og við hvaða samfélagslegu aðstæður. Með pví að bera finnsk-úgrísku málaættina saman við önnur tungumál innan úrölsku málaættarinnar, m.a. samójedísku málin, er ekki aðeins hægt að draga ályktanir um samskipti Sama við annað fólk um aldir, heldur einnig um lifnaðarhætti forfeðra Samanna. Málvísindamenn endurgera fortíðarmyndir sem byggðar eru á nútímalegum forsendum vegna pess að ritaðar heimildir frá pessum tímum eru að sjálfsögðu ekki til. 


\section{Tímabilið frá árinu 4000 til 2000 fyrir Krist}

Í samísku eru orð sem hægt er að rekja meira en 6000 ár aftur í tímann, t.d. njuolla (ör), juoksa (bogi), suotna (sin), guolli (fiskur), njoammil (héri). Dæmin eru úr norðursamísku. Dessi orð eiga stofninn sameiginlegan öðrum málum sem tilheyra úrölsku málunum - og í samísku eru á annað hundrað slíkir orðstofnar. Detta bendir til samskipta, á forsögulegum tíma, við fólk eða pjóðflokka úr austri, frá Úralfjöllum (finnsk-úrölsk mál) og frá Vestur-Síberíu (samójedísk mál)

Einnig er mögulegt að reikna út frá orðaforðanum hvenær ákveðnum samskiptum hefur lokið. Orð eins og t.d. goahti (tjald), liepma (kjötseyði), njuovvat (slátra) og lohkat (reikna eða lesa) og næstum pví 150 orð til viðbótar tilheyra tímabili sem getur hafa hafist fyrir um pað bil 6000 árum vegna pess að pau eru sameiginleg peim sem töluðu finnsk-úgrísk mál en eru ekki til í öðrum úrölskum málum. Detta bendir til að náin samskipti hópa, sem töluðu samójedísk mál, hafi hætt á pessum tíma.

Séu orð eins og beana (hundur), gáma (skór), reahpen (reykop í tjaldi) og mádjit (bjór) skoðuð á sama hátt væri hægt að komast að peirri niðurstöðu að nánum samskiptum við úgrísk mál, eins og t.d. ungversku, hafi lokið fyrir 5000 árum.

Forfeður Samanna áttu ekki einungis samskipti við fólk sem talaði finnsk-úgrísk mál heldur einnig við fólk sem talaði mál af indóevrópskum uppruna mjög snemma sögunnar. Flest málanna, sem nú eru töluð í Evrópu, tilheyra indóevrópsku málaættinni, t.d. germönsk og rómönsk mál, baltnesk og slavnesk mál, auk annarra mála í Suður-Asíu. Í bæði úrölskum og finnsk-úgrískum málum eru til indóevrópsk tökuorð, eins og t.d. suotna (sin), sem bendir til pess að samskipti hafi verið á milli pessara pjóðflokka fyrir meira en 6000 árum síðan.

\section{Tímabilið frá árinu 2000 fyrir Krist til 1000 eftir Krist}

Samkvæmt viðteknum kenningum eru samísku og eystrasaltsfinnsku málin, p.e.a.s. finnska og eistneska, runnin frá sameiginlegu samískfinnsku frummáli sem talað var fyrir u.p.b. 4000 árum (eða ennpá fyrr). Frá pessu máli komu svo frumsamíska og frumfinnska fyrir um pað bil 3000 árum. Álitið er að samíska hafi verið frekar einsleit 
á peim tíma en hafi breyst í núverandi mál eða mállýskur í kringum árið 800 samkvæmt okkar tímatali, p.e.a.s. fyrir um pað bil 1200 árum.

Á síðari árum hafa hins vegar verið settar fram tilgátur um að allavega suðursamíska hafi orðið viðskila við önnur samísk mál mun fyrr. Dessu til stuðnings er pví haldið fram að í suðursamísku sé að finna mörg gamaldags sérkenni, t.d. beygingarmyndir og flóknari sérhljóða en eru í öðrum samískum málum. Í orðaforðanum má einnig finna afar forn (baltnesk) tökuorð sem ekki er að finna í öðrum samískum málum.

Í aldanna rás hafa forfeður Sama líka átt samskipti við germanska pjóðflokka í púsundir ára og fengið mörg orð að láni frá peim, t.d. bassi (heilagur) og dohppa (hnífsslíður). Í samísku eru meira að segja tökuorð úr frumnorrænu. Dessi tökuorð benda til pess að samskipti milli menningarheima hafi hafist á fyrstu árhundruðum okkar tíma, t.d. áiru (ár), gáica (geit), gussa (kýr), vuostá (ostur). Mörg hundruð slíkra orða eru í samísku. Samarnir hafa einnig fengið mörg hundruð orð að láni úr frumfinnsku, t.d. bálká (laun), boallu (knappur), dávda (sjúkdómur), oastit (kaupa).

Af tökuorðunum er ekki einungis hægt að sjá við hverja Samar áttu samskipti á mismunandi tímabilum heldur einnig vísbendingar um á hvaða sviðum samfélagsins samskiptin hafa átt sér stað.

Að endingu má nefna að í nútímasænsku eru tökuorð úr samísku, t.d. $\operatorname{sarv}(<$ sarvvis $=$ hreintarfur $)$, rajd $(<$ ráidu $=$ '(ren)rajd'/ hreindýr) og nåjd (< noaidi = 'samisk schaman'/samísk). Mörg finnsk orð um hreindýrarækt hafa verið tekin að láni úr samísku, sérstaklega í norðurfinnskum mállýskum, t.d. urakka (<varik = 'hanren i tvåårsåldern' tvívetra hreindýrstarfur) og suopunki (< suohpan = lassó, snara).

\section{Fjöldi málhafa}

Í Sápmi búa um pað bil 60.000 Samar. Par af eru 35-40.000 í Noregi, 6.000 í Finnlandi, 15-20.000 í Svípjóð og 2.000 í Rússlandi. Tölurnar eru ónákvæmar, pær byggjast á mati. Til eru rannsóknir sem sýna fram á að tölurnar séu of lágar og langtum fleiri eigi rætur sínar að rekja til Sama án pess að vita af pví eða peir vilja ef til vill ekki vita af pví. 
Talið er að um pað bil 20.000 Samar kunni nokkur samísku málanna. Samísku málin á Kólaskaganum eru í hættu. Aðeins örfáir eldri borgarar tala tersamísku og akkalasamísku, sennilega nær tala peirra ekki 30, og hætta er á að pessi mál glatist. Kildinsamískan er málið sem flestir á svæðinu tala, 600-700 manns. Skoltsamísku tala einungis 20 manns í Rússlandi en flestir, sem tala skoltsamísku, búa í Finnlandi. Af um pað bil 2.000 samískum íbúum Rússlands kunna næstum 35-40\% samísku, aðallega kildinsamísku. Austursamísk mál, sem töluð eru í Finnlandi, eru enaresamíska og skoltsamíska. Næstum 500 tilheyra hvorum málhópi.

Norðursamísku tala 16-18.000 manns í Finnlandi, Noregi og Svípjóð, par af u.p.b. 9-10.000 í Noregi, 5-6.000 í Svípjóð og u.p.b. 2.000 í Finnlandi. Næstum pví 85-90\% peirra sem tala samísku tala norðursamísku.

Lulesamísku tala lauslega áætlað 800 manns í Svípjóð og Noregi að meðtöldum peim sem tala arjeplogssamískuna.

Aðeins fáeinir eldri málhafar tala umesamísku sem hætta er á að glatist en hina eiginlegu suðursamísku tala 600-800 manns í Svípjóð og Noregi.

\section{Gero samískra mála}

\section{Beyging sagna}

Samískan er afar fjölbreytt mál. Sagnirnar beygjast eftir frumlaginu og fá par með níu mismunandi myndir í nútíð vegna pess að í samísku er ekki einungis eintala og fleirtala heldur einnig tvítala. Myndir sagnarinnar borrat (borða) eru sýndar hér á eftir. Öll dæmin eru tekin úr norðursamísku (saN).

\begin{tabular}{ll}
\hline (mon) boran & (ég) borða \\
\hline (don) borat & (pú) borðar \\
\hline (son) borrá & (hann/hún) borðar \\
\hline (moai) borre & (við tvö) borðum \\
\hline (doai) borrabeahtti & (pið tvö) borðið \\
\hline (soai) borraba & (pau tvö) borða \\
\hline (mii) borrat & (við) borðum \\
\hline (dii) borrabehtet & (pið) borðið \\
\hline (sii) borret & (pau) borða \\
\hline
\end{tabular}




\section{Víxl í lengd og gildi hljóðs}

Í samísku er einstakt fyrirbrigði, svo kölluð víxl í lengd og gildi hljóðs, pað pýðir að samhljóðar í kjarna orða breytast við beygingu annaðhvort að lengd eins og í borat - borrá (sbr. dæmið að ofan) eða að eiginleika t.d. loddi fugl - lotti fuglsins. Mörg dæmi eru til um samhljóðavíxl sem skipta máli við beygingar á sögnum og nafnorðum. Sú staðreynd, að suðursamíska er eina afbrigði af samísku sem er án víxla í lengd eða gildi hljóðs, styður tilgátuna um að suðursamískan hafi orðið viðskila frá hinum samísku málunum afar snemma í sögunni.

\section{Föll}

Í samísku fá fallorð, p.e.a.s. nafnorð, lýsingarorð, fornöfn og töluorð, mjög oft mismunandi beygingarmyndir í stað forsetninga, t.d. (saN) váris (á fjöllum) sem er beygingarmynd (staðarfall) af várri (fjöll). Í samísku eru sjö föll. Í norðursamísku hafa eignarfalls- og polfallsmyndirnar fallið saman eins og myndirnar fyrir elativ og inessiv (og er venjulega kallað staðarfall).

\begin{tabular}{lll}
\hline nefnifall & sápmi & Sami \\
\hline eignarfall & sámi & Sama \\
\hline polfall & sámi & Sama \\
\hline illativ & sápmái & til Sama \\
\hline elativ & sámis & frá Sama \\
\hline inessiv & sámis & hjá Sama \\
\hline komitativ & sámiin & með Sama \\
\hline essiv & sápmin & eins og Sami \\
\hline
\end{tabular}

Enginn greinir er í samísku, hvorki ákveðinn né óákveðinn og t.d. getur sápmi pýtt Sami, Saminn eða einn Sami en pýðingin fer eftir samhenginu.

Einstaka forsetningar eru til í samísku, t.d. birra dálu (kringum húsið), en eðlilegast pykir að nota eftirsetningar sem standa á eftir aðalorðinu, t.d. dálu duohken (fyrir aftan húsið, eiginlega húsið fyrir aftan). 
Beygingarkerfið hefur í för með sér að orðaröðin er ekki jafn mikilvæg eins og t.d. í sænsku svo að merking sé ljós. Í setningunni Niila oaidná Máhte (Níls sér Matthías) er pað Níls sem sér Matthías jafnvel pótt orðaröðin væri önnur t.d. Máhte oaidná Niila. Orðið Máhte er beygt í polfalli og er andlag í setningunni en Niila stendur í nefnifalli og er frumlag í setningunni. Oftast er pó frumlagið á undan. Orðaröðin skiptir máli og getur haft áhrif á stíl eða hvert athyglinni er beint. Ekki er rétt að segja að í samísku sé frjáls orðaröð heldur að hún sé takmörkuð.

\section{Afleiðsla orða}

Fjölbreytileikinn er einnig sprottinn af möguleikunum á pví að mynda ný orð með svo kölluðum afleiðsluendingum. Af sögninni borrat (borða) er t.d. hægt að mynda eftirfarandi nýjar sagnir með afleiðsluendingum:

\begin{tabular}{ll}
\hline borralit & borða hratt \\
\hline borastit & borða lítið \\
\hline boradit & borða (máltíð) \\
\hline borahit & mata \\
\hline borahallat & vera bitinn \\
\hline borrojuvvot & borðandi \\
\hline
\end{tabular}

Auk pess að mynda sagnir af sögnum er hægt að mynda nafnorð af sögn, t.d. er af sögninni borrat hægt að mynda borramuš (pað að borða, p.e.a.s. mat). Til eru margir möguleikar á að mynda ný orð með pví að nota afleiðsluendingar en pó eru ekki allar endingar jafnafkastamiklar, p.e.a.s. pað eru takmörk fyrir notkun afleiðslu. Ný orð eru sífellt mynduð m.a. með pví að nota afleiðsluendingar t.d. dieđáhus (upplýsingar) af dieđihit (upplýsa), bagadeaddji (leiðbeinandi/ráðgjafi) af bagadit (gefa ráð/veita leiðsögn), čoavddus(lausn (á vandamáli)) af čoavdit (leysa), čálán (skrifari, enska printer) af čállit (skrifa). (Upplýsingar um sérstök tákn í samísku verða tilgreind hér á eftir). 
Til er sérstök sögn - neitunarsögn - sem er notuð í setningu með neitun, t.d. mon in dieđe (ég veit ekki). Neitunarsögnin beygist eftir persónu en aðalsögnin dieđe af diehtit (vita) stendur í nafnhætti og er óbeygð. Í pátíð er annar fallháttur af sögninni notaður.

\begin{tabular}{ll}
\hline mon in dieđe & ég veit ekki \\
\hline mii eat dieđe & við vitum ekki \\
\hline mon in diehtán & ég vissi ekki \\
\hline mii eat diehtán & við vissum ekki \\
\hline
\end{tabular}

\section{Tíð og háttur}

Auk nútíðar og pátíðar eru líka - eins og í skandinavísku málunum - sagnmyndir í núliðinni og páliðinni tíð (í framsöguhætti) myndaðar með hjálparsögninni leat. Í samísku er hjálparsögnin beygð í persónu, tölu og hætti.

\begin{tabular}{ll}
\hline son lea oastán ođđa biila & hann/hún hefur keypt nýjan bíl \\
\hline mon lean oastán ođđa biila & ég hef keypt nýjan bíl \\
\hline son leai oastán ođđa biilla & hann/hún hafði keypt nýjan bíl \\
\hline mon ledjen oastán ođđa biilla & ég hafði keypt nýjan bil \\
\hline
\end{tabular}

Framsöguháttur er háttur sem segir til um að pað sem sagt er á að skilja sem sannleika. Aðrir hættir í samísku eru boðháttur sem segir til um að pað sem sagt er á að skilja sem áskorun eða skipun, t.d. Boađe sisa! (Kom inn! - sagt við einstakling). Hefði verið um tvo að ræða hefði sögnin verið í annarri gerð: Boahtti sisa! Og um fleiri en tvo: Bohtet sisa!

Dar að auki geta sagnir verið í skildagatíð sem segir til um skilyrði, t.d. mon vuolggášsin dohko, jus ... (ég myndi fara pangað ef ...) og potentialis, sagnháttur sem táknar möguleika, segir til um vafa, t.d. in dieđe bođeš go son ihttin (ég veit ekki hvort hann kemur á morgun). Detta hefur í för með sér að af samískri sögn, eins og t.d. borrat (borða), er hægt að mynda 45 ólíkar beygingarmyndir. 


\section{Ritháttur og málhljóð}

Í norðursamíska stafrófinu eru eftirfarandi tákn:

\section{$a$ á b c čdđef $g h i j k I m n \eta \circ p r s \check{s} t \in u v z z ̌$}

Sérhljóðinn á er langur sérhljóði og greinir á milli framburðar á t.d. manná, hann fer' og mánná 'barn'. Sérhljóðinn $o$ er borinn fram eins og íslenskt o-hljóð og $u$ er borið fram eins og íslenskt ó-hljóð, t.d.

\begin{tabular}{lcc}
\hline loddi & [låd.di] & fugl \\
\hline unni & [on.ni] & lítill \\
\hline Punkturinn gefur til kynna nýtt atkvæði & \\
\hline
\end{tabular}

Táknið c stendur fyrir tse-hljóð og č fyrir tje-hljóð og z og ž eru samsvarandi rödduð hljóð, t.d.

\begin{tabular}{lll}
\hline čáhci & [tjah.tsi] & vatn \\
\hline vázzit & [vad.dsit] & fara \\
\hline oažžut & [oad.dtjot] & fá \\
\hline
\end{tabular}

Táknið š samsvarar sje-hljóði, t.d.

\begin{tabular}{lll}
\hline šaddu & [sjad.do] & vöxtur \\
\hline
\end{tabular}

Táknin đ og $t$ (ísl. ð og p) eru rödduð og órödduð önghljóð, t.d. (eins og í ensku bathe sbr. bath.)

\begin{tabular}{lll}
\hline lieđđi & [liedh.dhi] & rauđa \\
\hline muożá & [muoth.tha] & móðursystir \\
\hline
\end{tabular}




\section{Ritmál}

Fyrsta samíska bókin var prentuð árið 1619. Sænskur prestur í Piteå, Nils Andersson, hafði pýtt stafrófskver og litla messubók yfir á lélega suðursamísku. Flestar bækur, sem gefnar voru út á samísku á nítjándu öld, voru pýðingar á biblíunni eða öðrum kirkjubókum.

Á átjándu öld kom fram bókmál, hið svonefnda suđurlappneska bókmál, byggt á norðlægri suðursamísku og var ætlað að verða sameiginlegt ritmál allra Sama. Innan kirkjunnar og í skólum hafði suðurlappneska sterka stöðu. Jafnvel fram á nítjándu öld og á seinni hluta peirrar aldar voru ennpá gefnar út kennslubækur á pví máli en undir lok aldarinnar var útgáfu á suðurlappnesku hætt.

Fyrsta bókin á norðursamísku, spurningakver, var prentuð í Noregi árið 1728. Stafsetninguna hafði Knuud Leem prestur próað og hann gaf einnig út málfræði- og orðabækur. Seinna, á nítjándu öld, vann norski presturinn Nils V. Stockfleth að nýrri norðursamískri stafsetningu með sérstökum samískum táknum. J.A. Friis (sem varð prófessor í samísku og finnsku við háskólann í Osló 1866) tók saman stóra norðursamíska orðabók sem gefin var út árið 1887.

Norðursamiskt staðalmál - sem byggir á tilbrigðum frá Finnmörku - var skipulagt af Konrad Nielsen og stóra orðabókin hans var gefin út 1926-1929. Á grundvelli ritháttar Nielsens voru gefnar út norðursamískar stafsetningarreglur eftir Knut Bergsland og Israel Ruong árið 1948 (byggjast á mállýskunni sem töluð er í Kautokeino) og voru sameiginlegar fyrir Noreg og Svípjóð. Í Finnlandi var á sama tíma notuð önnur stafsetning fyrir norðursamísku sem unnin var af Paavo Ravila í kringum 1930 og seinna endurbætt af Erkki Itkonen á sjötta áratug tuttugustu aldar.

Á áttunda áratugnum próaði Samíska málnefndin sameiginlega stafsetningu fyrir norðursamísku í Noregi, Svípjóð og Finnlandi. Hún var viðurkennd af Norrænu Samaráðstefnunni og hefur frá pví árið 1979 verið notuð ílöndunum premur. Í norðursamísku stafsetningunni eru táknin (̌̌, đ, y, š, te, ž) notuð og pað skilur hana frá suðursamísku og lulesamísku.

Nú eru til sex mismunandi tilbrigði af stafsetningu fyrir samísk mál að undanskilinni norðursamísku: suðursamíska (staðfest 1978), lulesamíska (1983), enaresamíska, skoltsamíska og kildinsamíska. Í kildinsamísku er kyrillíska stafrófið lagt til grundvallar. 


\section{Málaðstæður í samfélaginu}

Samíska er fyrst og fremst notuð í samskiptum innan fjölskyldunnar og við nánustu vini og í hefðbundnum samískum atvinnugreinum eins og t.d. hreindýrarækt. Á síðustu áratugum hefur notkun hennar aukist á öðrum vettvangi, t.d. í fjölmiðlum, stjórnsýslu og kennslu. Detta er afleiðing aukinnar meðvitundar um samíska menningu og samísk mál sem „samíska menningarbyltingin“ á áttunda áratug síðustu aldar markaði upphafið að. Á peim tíma fór samískt „joik“ og tónlist að heyrast opinberlega í fyrsta sinn og samísk ljóðskáld lásu ljóð sín fyrir áheyrendur. Farið var að nota samísku í bókum og hún heyrðist við margs konar nýjar kringumstæður.

Málnotkun innan fjölskyldunnar er undirstaða pess að málið varðveitist. Ef foreldrar tala samísku við börnin sín munu börnin læra samísku. En pað er ekki síður mikilvægt að samískan sé notuð á fleiri sviðum. Detta á fyrst og fremst við um skólann og kennsluna. Dað er mikilvægt að samíska sé kennd á viðunandi hátt í skólanum til pess að málið próist eðlilega. Annað mikilvægt svið eru fjölmiðlar, sérstaklega sjónvarp og blöð. Til pess að mál próist vel purfa einnig að vera til fjölbreyttar bókmenntir. Ástandið er breytilegt hjá pví fólki sem talar mismunandi samísk mál í mismunandi löndum.

\section{Lagasetning}

Lagasetning veitir ekki alls staðar jafn mikla vörn fyrir hin ýmsu samísku mál. Norðursamíska nýtur vissrar verndar á vissum landfræðilegum svæðum vegna laga í Noregi, Svípjóð og Finnlandi. Deim sem tala samísku er m.a. veittur réttur til pess að nota samísku í samskiptum við pau yfirvöld sem bera ábyrgð á málefnum Sama. Í Noregi ná lögin yfir ákveðin sveitarfélög par sem samíska er töluð og í Finnlandi ná lögin yfir landsvæði par sem íbúarnir eru ekki einungis norðursamískir heldur einnig enare- og skoltasamískir.

Lagasetningin nær ekki inn á lulesamíska svæðið í Noregi og að engu leyti yfir suðursamísku hvorki í Noregi né Svípjóð. Í Rússlandi hafa engin lög verið sett um samísku málin. 
Með lagasetningu um mál í Noregi hefur fyrst og fremst verið lagður grundvöllur að umfangsmikilli vinnu við pýðingar á skjölum. Í Svípjóð hefur lagasetningin fram til pessa ekki haft mikil áhrif á notkun samísku hjá peim yfirvöldum sem lögin ná yfir. Ástæðuna má að miklu leyti rekja til pess hve margir Samar eru óvanir að nota túlka. Í stað pess að nota sitt eigið mál velja peir að tala sænsku sem peir hafa ekki jafn gott vald á. Við háskólann í Umeå fer nú fram kennsla fyrir norðursamíska túlka sem ætti að leiða til pess að notkun túlka verði viðtekin pegar peir sem tala samísku eiga samskipti við yfirvöld.

\section{Samíska í kennslu}

pað er einnig umtalsverður munur á framboði á kennslu og menntun í samískum málum. Norðursamíska hefur verið kennd á grunnskólastigi í Svípjóð, Noregi og Finnlandi um margra áratuga skeið og á framhaldsskólastigi, einkum í Noregi. Í Svípjóð eru sérstakir Samaskólar fyrir börn í 1. til 6. bekk. Í Samaskólunum er innihald kennslunnar lagað að samískum aðstæðum. Í nokkrum skólanna fer öll kennslan fram á samísku. Í skólunum í Kautokeino og Karasjok (í Noregi) fer kennsla einnig fram á samísku sem og í Ohcejohka (í Finnlandi). Tækifæri til pess að fá kennslu ílulesamísku, og svo ekki sé talað um suðursamísku, hafa verið takmörkuð og framboðið einungis verið kennsla í fáeina tíma í viku.

Norðursamíska hefur um alllangt skeið verið kennd í háskól-

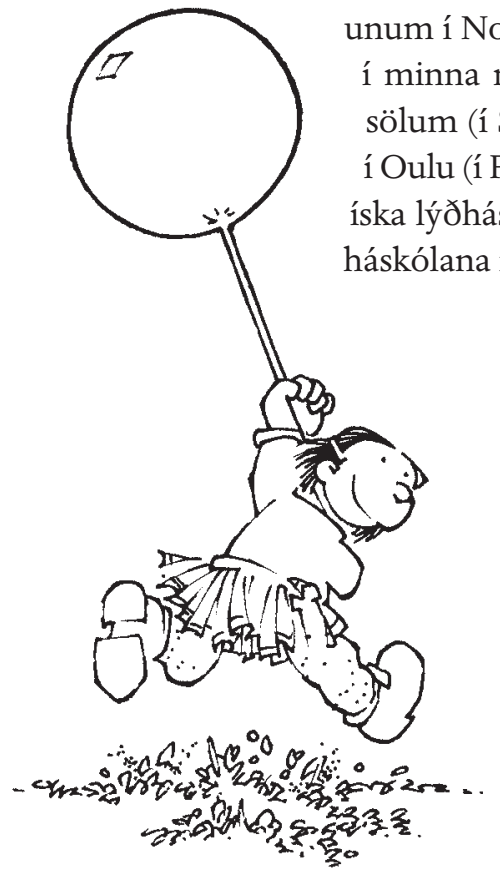




\section{Samíska í fjölmiðlum}

Framboð á fjölmiðlum er mismunandi. Til eru tvö norðursamísk dagblöð sem gefin eru út í norska hlutanum, Min Áigi (Tíminn okkar) og Áššu (Glæður). Fyrrnefnda blaðið var gefið út til reynslu í lulesamískri útgáfu einu sinni í viku í nokkra mánuði en peirri útgáfu hefur nú verið hætt.

Daglegar útvarpssendingar, aðallega á norðursamísku, eru í Noregi, Finnlandi og Svípjóð. Í Noregi og Svípjóð eru reglulegar útsendingar á lule- og suðursamísku og samsvarandi útsendingar í Finnlandi á enare- og skoltsamísku. Í Rússlandi eru nýlega hafnar útsendingar á kildinsamísku í samstarfi við ritstjórnir Sama í hinum Skandinavisku löndum. Rússneskir Samar hafa af pví tilefni fengið kennslu til pess að vera færir um að takast á við verkefnið.

Í sjónvarpi eru sendar út alla virka daga 15 mínútna fréttaútsendingar á norðursamísku í samvinnu Norðmanna, Svía og Finna. Samísku ritstjórnirnar framleiða einnig dagskrá fyrir börn á samísku sem er send út reglulega.

\section{Bókmenntir og tónlist}

Dótt fyrsta bókin á samísku hafi verið prentuð árið 1619 pá var pað ekki fyrr en í byrjun tuttugustu aldar að samískir rithöfundar fóru sjálfir að skrifa á samísku. Í Noregi skrifaði Anders Larsen skáldsöguna Beaivvi álgu (Dögunin) sem var gefin út árið 1912. Í Finnlandi kom ljóða- og smásagnasafn Pedar Jalvis Muohtačalmmit (Snjókorn) út árið 1915. Mikilvægari var samt útgáfan á bókJohan Turis Muitalus sámiid birra (Saga Samanna) sem var gefin út í fyrstu útgáfu árið 1910. Allar pessar bækur hafa verið gefnar út í nýjum upplögum og eru notaðar við kennslu í háskólum.

Frá 1970 og fram til pessa hafa margir samískir rithöfundar gefið út bækur og ljóðasöfn í Noregi, Svípjóð og Finnlandi, m.a. Paulus Utsi, Nils Aslak Valkeapää, Kirsti Paltto, Elle Marja Vars og margir fleiri. Af peim hefur Nils Aslak Valkeapää (sem á samísku hét Áillohaš) verið áhrifaríkastur sem rithöfundur, listamaður og joikari. Hann fékk bókmenntaverðlaun Norðurlandaráðs árið 1991 fyrir ljóðasafnið Beaivi áhčážan (Sólin, faðir minn) frá árinu 1988. 
Í ljóði lýsir Paulus Utsi lífi sínu með myndum úr náttúrunni.

$\begin{array}{ll}\text { Reagganan ráhkisvuohta } & \text { Kvalafull ást } \\ \text { Nu go roạkesoahki } & \text { Eins og kræklótt björk } \\ \text { orru duottarravddas } & \text { á brún fjallsins } \\ \text { nu lea biegga botnjan } & \text { er líf mitt } \\ \text { mu nai eallima } & \text { skekið af vindinum } \\ \text { Nu go soagi mátta } & \text { Eins og stofn bjarkarinnar } \\ \text { bievlla vuostá čuovgá } & \text { skín á nakta jörð } \\ \text { nu ohcalan váriide } & \text { langar mig til fjallsins } \\ \text { láguide ja oruhagaide } & \text { á slétturnar og búsvæđin } \\ \text { Dat lea mu eallin } & \text { Pannig er líf mitt } \\ \text { man mon ráhkistan } & \text { sem ég elska }\end{array}$

Joik og önnur samísk tónlist kom fyrst fram í sviðsljósið á áttunda áratug síðustu aldar og í fararbroddi fyrir peirri próun fór fyrrnefndur Nils Aslak Valkeapää. Hann gaf út plötu með joiki par sem hefðbundið joik er flutt með hljóðfæri. Plata hans hlaut einstakar viðtökur meðal Samanna og í kjölfarið fóru ungir Samar að koma fram á sviðið og joika og syngja samíska söngva. Síðar hélt hann pessu starfi áfram og gaf út marga geisladiska með samísku joiki, fluttu með hljóðfæri. Nú hafa komið fram margir samískir tónlistarmenn. Hin pekktustu eru Marie Boine (sem hlaut tónlistarverðlaun Norðurlandaráðs árið 2003) og Wimme Saari sem bæði hafa gefið út marga geisladiska.

Í mörg ár hefur verið haldin árleg tónlistarsamkeppni í Kautokeino á páskum. Dar keppa tónlistarmenn á tveimur sviðum, í joiki og samískri tónlist. Áhugi á pessari keppni hefur smám saman aukist og nú taka listamenn frá öllu Sápmi pátt í keppninni. Á pennan máta hefur tónlist haft mikil áhrif á notkun samísku í samfélaginu.

\section{Samfélagið að̃ öðru leyti}

pegar allt kemur til alls er staða norðursamísku sterk miðað við önnur samísk mál og mállýskur. Í Kautokeino og Karasjokk í norska hlutanum og Ohcejohka í finnska hlutanum (öll innan norðursamíska svæðisins) eru Samar í meirihluta í sveitarfélögunum. Á síðasta áratug hefur notkun samísku, pökk sé m.a. lagasetningu, aukist 
verulega innan stjórnsýslunnar. Á kortum yfir fjallasvæðin er nú algengt að staðarnöfn séu á samísku á peirri mállýsku sem er ríkjandi á viðkomandi svæði og á vegaskiltum standa einnig samísk nöfn, t.d. Giron (Kiruna).

Stofnun sérstakra Samapinga í Noregi, Svípjóð og Finnlandi hefur haft mikil áhrif. Fulltrúar Samapinganna eru kjörnir í kosningum viðkomandi landa af fólki sem er á kjörskrám pinganna og eru par með pjóðkjörnir pingfulltrúar Sama í viðkomandi landi. Samapingin hafa m.a. komið á laggirnar sameiginlegri Samiskri málnefnd sem er m.a. ábyrg fyrir áætlunum um samísku í samfélaginu. Í pessari málnefnd eru einnig fulltrúar rússneskra Sama.

Dýding úr scensku á islensku: Sigrún Kristín Magnúsdóttir

\section{Ritaskrá}

Hyltenstam, Kenneth, Christopher Stroud \& Mikael Svonni (1999):

„Språkbyte, språkbevarande, revitalisering. Samiskans ställning i svenska Sápmi“'. I: Kenneth Hyltenstam (ritstj.): Sveriges sju inhemska språk - ett minoritetsspråksperspektiv. 41-97. Lund: Studentlitteratur.

Korhunen, Olavi (1997): „Hur samiskan blev samiska“. I: Eva Westergren \& Hans Åhl (ritstj.): Mer än ett språk.
En antologi om två- och trespråkigheten i norra Sverige. 79-115. Norstedts ordbok.

Magga, Ola Henrik (1997): ,Samisk språk“. I: Språkene i Norden. Utgitt af Nordisk språksekretariat. 137-160. Oslo: Novus.

Sammallahti, Pekka (1998): An Introduction to Saami Languages. Kárášjohka: Davvi Girji.

\section{Vefslóðir}

Samískar rannsóknir, Umeå universitet:

Sámi Allaskuvla, Kautokeino:

Giellagas, Oulu universitet:

Samískar rannsóknir, Universitet i Tromsö:

Nordiskt samiskt institut, Kautokeino:

Samapingið í Svípjóð:

Samapingið í Noregi:

Samapingið í Finnlandi:
www.umu.se/samiska
www.samiskhs.no
www.giellagas.oulu.fi
www.sami.uit.no
www.nsi.no
www.sametinget.se
www.samediggi.no
www.samediggi.fi 



\section{CARL CHRISTIAN OLSEN}

\section{Kalaallisut - grænlenska}

Aðaltungumálið á Grænlandi nefnist kalaallit oqaasii eða kalaallisut. Um pað bil 50.000 manns tala pað en hluti peirra er tvítyngdur og talar dönsku sem annað mál. Sögulega er kalaallisut skylt fjölda annarra eskimóamála sem eru af eskimó-aleúsku málaættinni en í henni eru eskimóamál og aleúska meginstoðirnar (sjá mynd 1).

\section{Samband tal- og ritmáls}

Eins og í öllum tungumálasamfélögum er gerður greinarmunur á talmálinu kalaallisut með fjölda aðalmállýskna, sem pó eru allar gagnkvæmt skiljanlegar, og svo ritmálinu kalaallisut. Grænlenska ritmálið, sem allir Grænlendingar nota, gegnir sama hlutverki og önnur staðalmál. Баð er notað í menntakerfinu, í fag- og fagurbókmenntum, í prentmiðlum og til að texta sjónvarpsefni.

Upphaflega var undirstaðan undir próun ritmálsins miðvesturgrænlenska mállýskusvæðið. Par er höfuðborgin Nuuk, áður Godthåb, og par var og er ennpá mikilvægasta menntastofnunin á gamla Grænlandi, kennaraskólinn Ilinniarfissuaq. Grundvöllurinn að grænlenskri bókmenntahefð var lagður par á árunum um 1860.

Eins og búast má við er núverandi ritmál skiljanlegt öllum sem tala grænlensku par sem hluti orðaforðans er frá mállýskusvæðunum úr norðri og suðri og líka frá avanersuaq (Thule) og tunu (p.e. úr austurgrænlensku en par eru tvö mikilvæg mállýskusvæði, Ammassalik-svæðið og Illoqqortoormiut-svæðið (Scoresbysund-svæðið) (sjá mynd 1)). Aftur verður vikið að próun ritmálsins í síðasta hlutanum.

Drátt fyrir að mállýskur ystu mállýskusvæðanna séu ekki beinlínis gagnkvæmt skiljanlegar er uppbygging tungumálsins á öllu svæðinu eins. Langflestir skilja hver annan eftir dálítinn aðlögunartíma. 


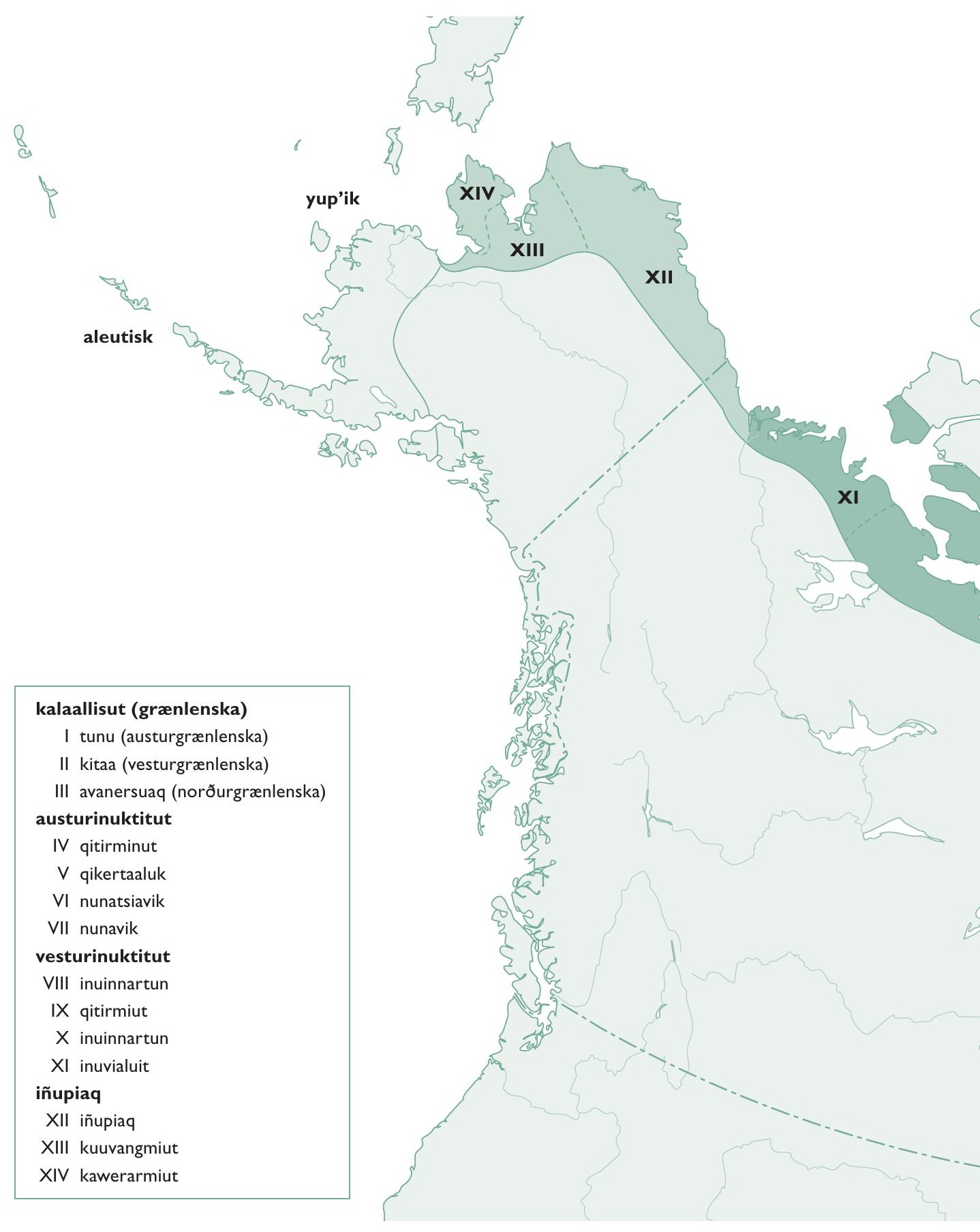

Mynd 1: Ef á heildina er litið tala um pað bil 150.000 manns inúítamálin að međtöldum innflytjendum í Bandaríkjunum og Suður-Kanada, Danmörku og ađalsvæđum í Rússlandi. 

(2)

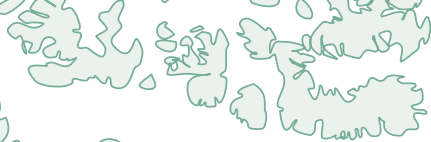
को
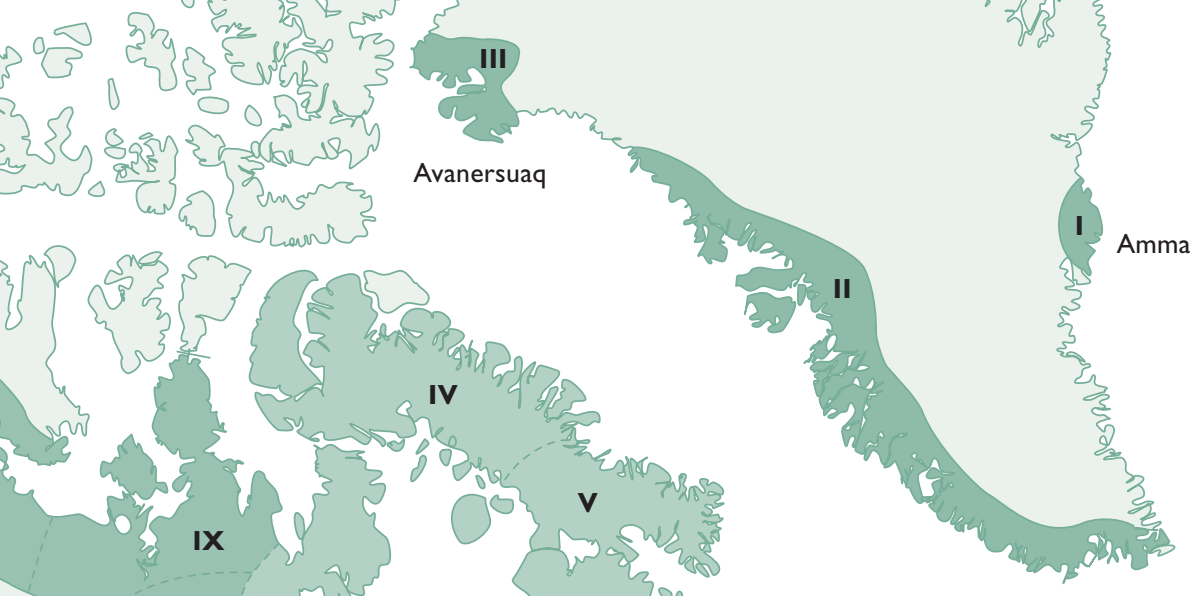

III

(Scoresbysund) 


\section{Grænlenskar mállýskur}

Í grænlensku eru prjár meginmállýskur: avanersuaq (nyrsti hluti Grænlands), tunu (Austur-Grænland) og kitaa (Vestur-Grænland).

Innan pessara meginsvæða eru allmargar undirmállýskur, sérstaklega á pað við um vesturgrænlensku. Frá Uppernavik í norðri til Hvarfs (Kap Farvel) í suðri er málfarið fjölbreytilegt sé tekið tillit til framburðar, orðavals og hreims (p.e. hljómfallsins í tungumálinu) og á sumum svæðum getur verið um beygingarfræðilegan og málfræðilegan mun að ræða, p.e. reglur um orðmyndun og setningafræði eru mismunandi.

\section{Hvernig er paơ sagt á grænlensku?}

Pegar rætt er um Grænland er mikilvægt að gera sér grein fyrir að nafnið Grænland gáfu utanaðkomandi aðilar landinu, fyrstu norrænu mennirnir, p.e.a.s. fólk sem flutti frá Noregi og fann „Grænland“ og gaf landinu nafn árið 982. Á kalaallisut heitir landið Kalaallit Nunaat. Grænlendingar nota sjálfir önnur orð um íbúa landsins sem líka verða notuð hér.

\section{Inúki/inúíti}

Inúki, í fleirtölu inúitar er heitið sem Grænlendingar og aðrir inúitahópar nota um sjálfa sig. Orđið inúki pýđir manneskja. Utanaðkomandi kölluðu Grænlendinga fyrr á tímum eskimóa.

\section{Eskimói}

Orðið eskimói er talið vera úr indiánamáli sem nú er talað í kanadíska héraðinu Québec. Fyrstir til að nota orðið voru jesúítatrúbođar í upphafi sautjándu aldar. Ein túlkun á orđinu og sú sennilegasta er að pað merki „peir sem borða hrátt kjöt“. Öllu forvitnilegri túlkun leiðir orðið aftur að „ekskommunikeret“ (p.e. vísað úr kapólsku kirkjunni).

\section{Kalaaleq}

Kalaaleq, í fleirtölu: kalaallit. Ekki er vitað hvaðan orðið er komið en nú er pað notað yfir íbúa á Grænlandi. Ef til vill hefur hugtakið orðið til vegna pess að peir fyrstu, sem komu til Grænlands, héldu að landtenging væri á milli Grænlands og finnska svæðisins Karelíu og pađan voru margir hvalveiðimenn. Poul Egede, sonur Hans Egede, norska prestsins sem var trúboði á Grænlandi, nefnir í orðabók sinni að Grænlendingar kalli sig sjálfa inúíta en kynni sig sem kirjála (kareler/kalaallit) fyrir ókunnugum. 
Saga Grænlands hefur verið rannsökuð lengi og málvísindamenn og fornleifafræðingar eru nú á peirri skoðun að fólk hafi flust til Grænlands í fjórum lotum. Fólkið, sem settist par að, var í öllum tilvikum eskimóar. Mállýskurnar endurspegla á vissan hátt pessar lotur.

\section{Einkenni grænlenska tungumálsins}

\section{Viðskeytamál}

Grænlenska tungumálið, kalaallisut, er greinilega frábrugðið öðrum málum sem töluð eru í Vestur-Evrópu og framhaldsskólanemendur á Norðurlöndum pekkja sem erlend tungumál, eins og t.d. pýsku, ensku, spænsku og frönsku. Í peim málum er aðeins einn eða fáir stofnar í hverju orði (eins og t.d. vínglas sem er samsett af stofnunum vín + glas) en í kalaallisut geta oft verið margir stofnar í einu orði. Рað hefur í för með sér að orðin eru löng og flókin.

Tungumál, par sem stofnar eru límdir saman, eru kölluð viðskeytamál, (á ensku kallast pau agglutinating language, sbr. enska orðið glue) og eru pau afar algeng víða í heiminum en ekki í Vestur-Evrópu.

\section{Samsett og flókin orð}

Sem dæmi um samsett orð, sem svarar saman-aftur-kemur-víst-1. pers. et. til heillar setningar á Norðurlandamáli, (pað lítur nú út fyrir að veðrið fari má nefna: Silagissiartuaarusaarnialeað skána). Athugið að veður er í runarpoq. Pað má greina í: sila-gi1. persónu eintölu á kalaallisut. ssi-artu-aa-rusaar-nia-ler-unar-poq: Athugið einnig kaflann um setningaveður-gott-verður-fer yfir-hægt-smám fræði hér á eftir.

\section{Ergatíft tungumál}

Annað dæmigert einkenni kalaallisut er að pað er ergatift mál. pað einkenni snertir fallanotkun í áhrifssetningum (setningum með bæði frumlag og andlag) og í áhrifslausum setningum (setningum, án andlags). Í Vestur-Evrópu eru grænlenska og baskneska einu ergatífu tungumálin. 
Í beygingarmálum eins og latínu, pýsku og íslensku er frumlag í nefnifalli bæði í áhrifssetningum og áhrifslausum setningum en ef andlag er í setningunni er pað í aukafalli. İ ergatífum málum er frumlag 1 áhrifssetningu hins vegar í öðru falli en frumlag í áhrifslausri setningu. Í ergatífum málum flokkast frumlag í áhrifslausri setningu á „,sama hátt" setningafræðilega og andlag í áhrifssetningu. Dað hefur í för með sér að frumlag og andlag eru í sama falli í pessum tveimur mismunandi gerðum setninga (nefnilega absolutivus) en frumlagið í setningu með andlagi (áhrifssetningu) er í öðru falli, pví sem í gamla daga var kallað ergatíf. Nú er pað kallað relativus.

\section{Áhrifs- og áhrifslausar setningar}

Í setningunni 'Pétur borðar kjötið' hefur orðið 'Pétur' (Piitaq, tökuorð) myndina Piitap með endingunni - $p$ vegna pess að pað er frumlag í áhrifssetningu: Piitap neqi nerivaa og ending sagnarinnar -vaa sýnir að pað er andlag (p.e. kjötið). Neqi er par fyrir utan af sama stofni og neri-, að borða var upphaflega að eyða kjöti.

Í setningunni 'Pétur borðar' (áhrifslaus setning) er Piitaq í absolutivus og setningin hljómar: Piitaq nerivoq. Á endingu sagnarinnar -voq sést að setningin er áhrifslaus.

\section{Beygingarfræðileg tengsl}

Orðmyndun í kalaallisut er hægt að lýsa með notkun hugtakanna: stofn, viðskeyti og ending.

Líkt og í öðrum tungumálum vísar stofn orðs til „einhvers í veröldinni“", hlutar eða gjörðar en á kalaallisut eru stofnarnir ekki fyrir fram skilgreindir sem annaðhvort nafnorð eða sagnir. Orðið neri (borða), sem er notað í sýnishorninu hér á eftir, er dæmi um slíkan stofn.

Endingar eru einnig pekktar í vesturevrópskum málum, sérstaklega í málum með persónuendingum. Á pýsku er 2. persóna eintölu 
látin í ljós með -st. Á kalaallisut táknar endingin -punga 1. persónu eintölu. Takið eftir að á kalaallisut er gerður greinarmunur á sögnum, sem taka með sér andlag (áhrifssögnum), og peim sem gera pað ekki (áhrifslausum sögnum). Endingarnar eru mismunandi eftir persónum, sbr. kaflann hér að framan um ergatíf tungumál.

Að endingu erum að ræða orðhluta sem við köllum til einföldunar viðskeyti og pjóna pví hlutverki á kalaallisut að tilgreina nákvæmlega margs konar sambönd sem eru látin íljós með hjálparsögnum í norrænum tungumálum (kunne, burde, skulle, ville, have, måtte (hafa, munu, skulu, eiga, fá, geta)) eða lýsingarorðum.

\section{Oromyndun í grænlensku}

Nú getum við lýst orðmyndun í grænlensku á eftirfarandi hátt:

\{Stofn- $\quad$ x-fjöldi viðskeyta- endingar

Sé grænlensku orði skipt eftir pess konar liðum gæti pað t.d. litið út á eftirfarandi hátt:

Neriartor-nia-lerpunga

Pýtt lið fyrir lið:

(borða-)

(hreyfa-sig-aftur-

(1. pers. eintala,

á-byrjandi-)

án andlags)

\section{Orðrétt pýðing:}

'Ég ætla að fara pangað til pess að borða'

Merking:

'ég ætla að fara að borða'

Sérhvert orð getur tekið við næstum óendanlega mörgum myndum ummæla eða orðatiltækja. Viðskeytin geta stigbreyst, sýnt blæbrigði, tíma, staðfest eða hrakið o.s.frv. Að ofan var sýnt dæmi um orð sem samsvarar heilli setningu á íslensku. Dað hefur stofn, mörg viðskeyti og persónuendingu. En einnig er hægt að tengja endingar við stofna og láta par með í ljós ákveðið fall. Dá er litið á stofninn sem nafnorð. 


\section{Föll}

Eins og fram kom í kaflanum um ergatíf mál hér að framan eru í kalaallisut tvö meginföll, absolutivus og relativus.

\section{Absolutivus}

Piitaq nerivoq: 'Pétur borðar'

(Piitaq er í pessu dæmi í absolutivus vegna pess að ekkert andlag er í setningunni)

\section{Relativus}

Piitap neqi nerivaa: 'hann borðar pað', 'Pétur borðar kjötið'

(Hér er Piitaq í relativus og hefur pannig breyst í Piitap vegna pess að pað er andlag í setningunni sem einnig sést á endingu sagnarinnar nerivaa)

Að auki eru sex önnur föll sem sýna tengsl sem á norrænu tungumálunum eru tjáð með forsetningum:

\section{- Staðarfall}

-mi (samsvarar págufalli í pýsku og stađarfalli í rússnesku)

Piitaq Nuummi (Nuuk + mi) inuuvoq:

'Pétur er fæddur í Nuuk'

\section{- Stefnufall}

-mut (samsvarar polfalli í pýsku og latínu)

Umiarsuaq Qaanaamut (Qaanaaq + -mut) tikippoq:

'Skipið/skip er komið til Qaanaaq'

\section{- Upprunafall}

-mit

Timmisartoq Københavnimit (København + -mit) aallarpoq:

'Flugvélin tók á loft frá Kaupmannahöfn'

\section{- Tækisfall}

-mik (samsvarar tækisfalli í rússnesku)

Allunaasaq savimmik (savik 'kniv' + -mik) kipivaa:

'Hann/hún sker reipið með hníf' 


\section{- Samanburðarfall}

-tut

Qulleq seqinertut (seqineq 'sol' + -tut) qaamatiginngilaq:

'Lampinn skín ekki jafnskært og sólin'

\section{- Leiðarfall}

-kkut

Aqqusinikkut (aqqusineq 'vej' + -kkut) pisuppunga:

'Ég geng á veginum'

Takið eftir að hvorki kyn né ákveðni er sýnt á málfræðilegan hátt í kalaallisut. (Dess vegna stendur hann/hún í pýðingunni og skipið/skip).

\section{Persónuendingar}

Í grænlensku eru prjár persónuendingar auk afturbeygðs fornafns í priðju persónu.

\section{Anaanani napparsimammat atuanngilaq:}

Hann gengur ekki í skóla vegna pess að móðir hans (eigin) er veik.

(anaana móðir + -ni hans eigin napparsima veik -mmat kausativ

+ 3. pers. et. atua ganga í skóla + -nngi ekki -laq 3. pers. et)

\section{Napparsimagami atuanngilaq:}

Hann gengur ekki í skóla vegna pess að hann er veikur (naapparsima veikur + -ga kausativ + -mi 3 . pers. afturbeygð (hann sjálfur) atua gengur í skóla + -nngi ekki -laq 3. pers. et.)

Piitaq napparsimagami ilaangilaq:

Pétur er ekki með vegna pess að hann (sjálfur) er veikur

(Piitaq Pétur napparsima veikur + -ga kausativ + -mi 3. pers. afturbeygठ (hann sjálfur) ilaa er með + -nng ekki + -laq 3. pers. et.)

\section{Piitaq napparsimammat pulaarparput:}

Við heimsækjum Pétur vegna pess að hann er veikur

(Piitaq Pétur napparsima veikur + -mmat kausativ 3. pers. et. (vegna pess að hann) pulaar heimsækja + -parput 'afturbeygð 3. pers. ft. frumlag, 3. pers. et. andlag) 


\section{Viðskeyttar endingar}

Sameiginlegt öllum inúítamálum er fjöldi sérstakra endinga sem öllum er bætt við eftir að setningunni eða setningarhlutanum, með nauðsynlegum fylgiorðum, er lokið. Svokallaðar viðskeyttar endingar eru: -mi (staðfestandi/styrkjandi), -gooq (að pví er sagt er), -li (hins vegar), -lu (og), -luunniit (eða), -lusooq (eins og), -taaq (líka), -toq (ósk).

\section{Orðmyndun sem tengist viðskeyttum endingum}

$\{$ Stofn+ $x$-fjöldi viðskeyta + persónuendingar $\}+$ viðskeyttar endingar.

ajunngilaq

ajunngilarmi

ajunngilarooq

ajunngilarli

ajunngilarlu

uanga illilluunniit pað er gott

ajunngilaq + -mi styrkjandi: nú er nóg komið!

ajunngilaq + -rooq: eftir pví sem sagt er er pað gott

- eða: pað er sagt að pað sé gott

ajunngilaq + -li: en pað gekk vel

ajunngilaq + -lu: og pað er gott

uanga (ég) illit (pú) + luuniit: ég eða pú?

\section{Ađalsagnir og hjálparsagnir}

Í kalaallisut eru tvær myndir sagna, aðalsagnir og hjálparsagnir. Dær samsvara samt ekki myndum sagna í norrænum tungumálum vegna pess að hluti grænlenskra hjálparsagna gefur til kynna pað sem í peim málum er sagt í aukasetningum.

\begin{tabular}{lll}
\hline $\begin{array}{l}\text { Dæmi um aðalsagnir } \\
\text { framsöguháttur }\end{array}$ & pisuppunga & ég fer \\
$\begin{array}{l}\text { spurnarháttur } \\
\text { boðháttur }\end{array}$ & $\begin{array}{l}\text { pisuppa? } \\
\text { pisugit! } \\
\text { óskháttur }\end{array}$ & $\begin{array}{l}\text { farðu! } \\
\text { pisullanga }\end{array}$ \\
\hline $\begin{array}{l}\text { Dæmi um hjálparsagnir } \\
\text { rökháttur: }\end{array}$ & & \\
samtímaháttur: & pisummat & vegna pess að hann fór \\
framtíðarháttur: & mens & um leið og ég fer \\
skýringarháttur & pisukkuma & pegar ég fer \\
\hline
\end{tabular}




\section{Próun kalaallisut sem ritmáls}

Eins og greint var frá í inngangi er ekki hefo fyrir ritmáli í tungumáli inúíta. Ritmálinu var komið á vegna prýstings utan frá.

Frá pví að fyrstu samskiptin við Evrópu áttu sér stað hafa verið gerðar tilraunir til pess að festa grænlenskt ritmál í sessi. Heiðurinn af fyrstu skipulögðu tilrauninni er eignaður Hans Egede (1680-1758) og meðhjálpara hans Albert Topp en árið 1728 gerðu peir tilraun til pess að pýða sköpunarsöguna. Sonur Hans Egedes, Poul Egede (17081789), gaf út orðabók á grænlensku, dönsku og latínu. Poul Egede óx úr grasi á Grænlandi og lærði málið í barnæsku. Grundvöllur að fyrstu kerfisbundnu stafsetningunni var samt ekki lagður fyrr en árið 1851 af mótmælandanum Samuel Kleinschmidt (1814-1886).

Samuel Kleinschmidt var mikilhæfur hljóðfræðingur sem bjó til stafsetningu sem varðveitti form stofna og viðskeyta á líkan hátt í öllum samsetningum. Dess vegna varð grænlensk stafsetning næstum pví jafn orðhlutafraeđilega rétt og nútímadanska, p.e.a.s. auðveld í lestri en stafsetningin var erfið vegna pess að pað voru engin augljós tengsl á milli hljóðs og ritunar. Framburður viðskeytanna fer nefnilega eftir umhverfinu.

Stafsetning Kleinschmidts var notuð til víðtækrar starfsemi sem bæði snerti tungumálið og fræðslu og sneri jafnt beint að inúítum sjálfum og umheiminum. Dar sem hún var sjálfri sér samkvæm varð hún undirstaða hins eiginlega ritmáls. Hún kom til að mynda að góðum notum við pýðingu Biblíunnar en til pess varð að próa grænlenskan íðorðaforða á fleiri sviðum, t.d. hugtök um samfélagstengsl, tegundir náttúru og siðfræðihugtök sem höfðu ekki verið til í grænlensku.

Á mörgum mállýskusvæðum inúíta utan Grænlands er Biblían pað eina sem til er á ritmáli. En Kleinschmidt tókst að leggja grundvöll að ákveðnu samræmdu stafsetningarkerfi og pað varð undirstaða pess að hægt væri að skrifa alls konar texta á málinu og bauð einnig upp á tækifæri til að skrifa pær fjölbreytilegu bókmenntir sem skilja grænlensku frá öðrum veiðimannasamfélögum. Hægt var að skrá eigin menningu og pýða hluta heimsbókmenntanna auk pess að túlka Grænland nútímans á eigin tungumáli og að vissu marki var hægt að nota tungumálið við stjórnsýslu. 
Réttritun Kleinschmidts var notuð fram til 1973 pegar innleidd var ný hljóðfrceðistafsetning sem auðveldaði ritun mikið vegna pess að ritmálið endurspeglar eftir aðstæðum framburðinn. Eftir meginreglum pessarar nýju stafsetningar er hægt að skrifa allar grænlenskar mállýskur, að undanteknum fáeinum sérstökum tilvikum í framburði. Prátt fyrir að nýja stafsetningin hafi verið sampykkt eru ekki allir hættir að nota pá gömlu. Stjórnvöldum hefur pó verið gert að nota nýju stafsetninguna.

\section{Staðalgrænlenska}

Með stofnun Ilinniarfissuaq/ Kennaraháskóla Grænlands í Nuuk og Ilulissat árið 1845 var smám saman lagður grunnur að staðalgrænlensku, í upphafi með sameiginlegri stafsetningu en síðan varð talmálið fyrir eins konar stöðlun pannig að nú er með nokkru öryggi hægt að tala um staðalgrcenlensku. Staðalgrænlenska byggist á vesturgrænlenskum mállýskum sem notaðar voru við kennslu í skólanum. Síðar hefur petta talmál öðlast opinbera viðurkenningu með orðabókum og stafsetningu. Dá er til Grænlensk málnefnd.

Á meðan á stöðlunarferlinu stóð voru m.a. sérstök norðurgrænlensk orð sem varða vetrarveiðar á ísnum og suðurgrænlensk orð yfir ræktun húsdýra og landbúnað tekin með í orðaforðann (orðabókina). •að styrkir stöðu grænlenskunnar. Umræðunni um hvaða stafsetning á að hljóta opinbera viðurkenningu er lokið en um leið eru tilbrigði í mállýskum viðurkennd í talmáli. Til dæmis heitir rúgbrauðið opinberlega iffiaq en meðal tilbrigðanna eru ikkiaq, ippiaq, tiggaliaq, timiusiaq. Stöðlunin útheimtir einnig að notuð séu sameiginleg staðar- og

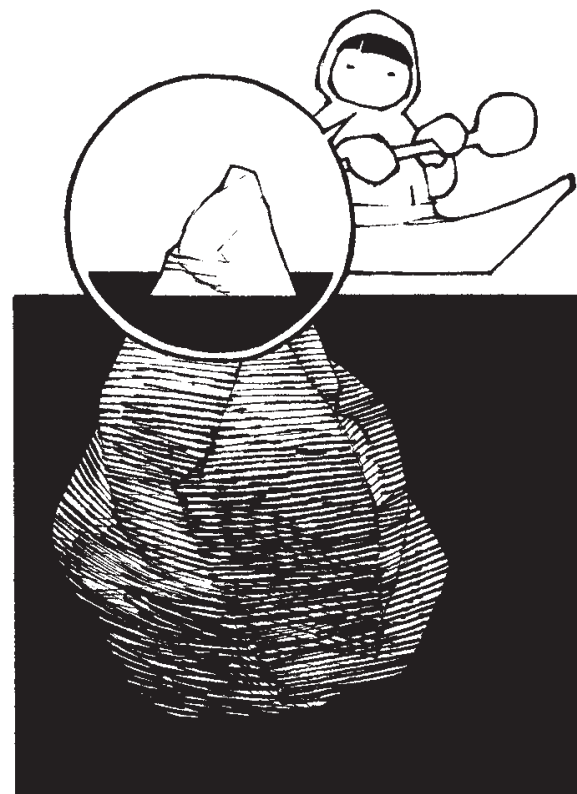
mannanöfn en par gefst líka svigrúm fyrir svæðisbundin tilbrigði. 


\section{Tökuorð og framandorð}

Í grænlenskri málstefnu er eins og í öðrum málum gerður greinarmunur á tökuorðum og framandorðum.

Ýmiss konar samskipti við fólk af fjölbreytilegum uppruna hafa ýtt undir fjölda ólíkra framandorða. Til dæmis er hægt að nefna fimm orð sem margir telja að séu komin frá Norðurlandabúum:

$\begin{array}{ll}\text { niisa } & \text { grindhvalur } \\ \text { sava } & \text { sauður (sbr. norsku: 'sau') } \\ \text { kuanneq } & \text { hvönn } \\ \text { kona } & \text { kona } \\ \text { musaq } & \text { gulrót (sbr. norsku: 'mura') }\end{array}$

Fólk frá Íslandi, Danmörku, Noregi, Frakklandi, Englandi, Skotlandi, Írlandi og Rússlandi, sem settist að á Grænlandi, hefur lagt til orðaforða kalaallisuts á mörgum sviðum, t.d. töluorð, tæknihugtök, orð yfir efni, siglingafræði, landbúnað og húsdýrarækt auk heita á nýlenduvörum og öðrum neysluvörum.

Inúítamálin eru um margt lík að gerð og pau eru mörg gagnkvæmt skiljanleg í dag en mismunurinn liggur m.a. í tölunum frá 1 til 12. Dær eru litaðar af áhrifum af samskiptum við ríkjandi evrópskar pjóðir. Meðal inúíta í Chukotka má finna töluorð af rússneskum uppruna, ensk-amerísk töluorð meðal inúíta í Alaska og Kanada og sum töluorð eru úr pýsku meðal inúíta á Labrador. Áður fyrr voru einnig pýsk töluorð í máli safnaða herrnhúta á

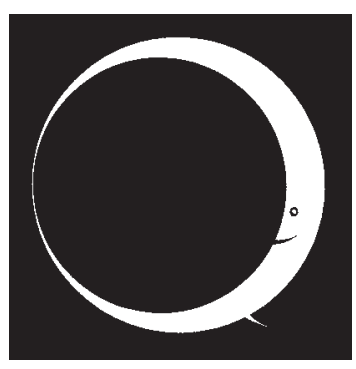
Gænlandi. Dönsk töluorð eru í grænlensku inúítamáli.

Sama á við um orðin sem voru notuð yfir fyrstu innfluttu nýlenduvörurnar, hluti og hugtök. Í Yup'ik í Alaska eru t.d. til mörg orð um nýlenduvörur og (kristin) hugtök yfir trú frá rússneska tímabilinu í Alaska. Dar að auki hefur mörgum tæknihugtökum í inúítamállýskum verið breytt 1 inúítamál eins og: qaammataasaq eitthvað sem virkar eins og tungl = gervitungl, silakkuarun (iñupiaq) eitthvað sem gerist í loftinu = útvarp, nagguteeraq (grænlenska) eitthvað sem minnir á disk af ís = skipakex (sporöskjulagað). Að pýða hugtökin synd og heilagur á grænlensku tók mörg ár. 
Mörg orðasambönd, eins og inussiarnersumik inuulluaqqusillunga með bestu kveðju, eru orðin vinsæl. Orðmyndun kalaallisuts með viðskeytum sníður tökuorðum pröngan stakk. Ekki er hægt að taka allt orðfæri beint upp í inúítamálið og pess vegna eru eiginlega fá málfræðileg lán í kalaallisut.

Eftir margra ára sambúð með dönsku og öðrum evrópskum málum hafa hljóð og hljóðreglur, sem áður var ekki hægt að nota, unnið sér sess. Af peim sökum eru nú beinlínis mörg framandorđ í málinu.

Alpjóðleg íðorð og heiti eru viðurkennd sem framandorð. Samt er hægt að notfæra sér pað sem kallast grænlenskt nýyrđi, p.e.a.s. orð sem byggist á kalaallisut-páttum til pess að ná yfir sama heiti og framandorðið. Sem dæmi um nýyrði má nefna: qarasaasiaq, tölva (orðrétt: unninn hlutur sem minnir á heila, sbr. rafheili).

Tökuorð eru pau orð sem eru svo sampætt grænlenskri málvenju að á pau er ekki lengur litið sem framandorð. Dau hafa verið aðlöguð grænlensku hljóðkerfi: januaari, sukulupooq (skyrbjúgur), kaffi. Öðrum hafa verið gefin grænlensk heiti svo að pau virka ekki framandi: sioraasat (strásykur), qarasaasiaq (tölva), nagguaatsoq (fill), pujorsiut/sammivissiut (áttaviti).

Samkvæmt opinberri málstefnu er grænlenska aðaltungumálið og danska telst fyrsta og enska sem annað tungumál.

\section{Stađa málsins}

Í grænlenskri umræðu hefur mönnum verið afar umhugað um stöðu kalaallisut. Mun málið í framtíðinni verða undir í samkeppninni við dönsku og ensku? Er e.t.v. hætta á pví að pað hverfi alveg? Og er hægt að snúa við peirri próun? Um pessar mundir ríkir viss bjartsýni. Kalaallisut lifir sem ritmál og er mikið notað af öllum hópum í samfélaginu: Lögpingið, löggjafarsamkundan, notar pað sem sitt mál: löggjöfin er skrifuð, rædd og sampykkt á grænlensku. Fjölmiðlarnir eru tvítyngdir, par er töluð grænlenska og danska og í kirkjunni er kalaallisut notað. Menntakerfið er orðið grænlenskt, p.e. grunnskólakennsla fer meira eða minna fram á grænlensku eða grænlenska er hluti náms í menntaskólanum.

Annað mikilvægt atriði er að Grænlendingar, sem sækja sér framhaldsmenntun, fara venjulega að nota grænlensku við vinnu sína. Innan vissra greina eins og í verslunar- og tæknigreinum, lögfræði 
og verkfræðigreinum er pörf á að próa grænlensk hugtök en mestu máli skiptir að vinna sigur á öllum sviðum menntunar, jafnt styttri sem lengri: kalaallisut í kennslubækur grunnskólans, menntaskólans, kennaraskólans og háskólans og kalaallisut við kennslu í allri framhaldsmenntun.

Táknrænt gildi tungumálsins er allt of mikið til pess að hægt sé að líta fram hjá pví í framhaldsmenntuninni og við nýsköpun sérfræðipekkingar á grænlensku í framtíðinni.

рað hefur verið viðurkennt að kalaallisut hefur ekki náð jafnvægi og óhætt er að segja að málið sé í örri próun. Á meðan að víða annars staðar er rætt um tuttugu ár á milli kynslóða tungumála er frekar um að ræða fimm til tíu ára bil á milli kynslóða í grænlensku. En á Grænlandi er einnig ungt samfélag sem krefst pess að fá pjónustu á eigin tungumáli. Framtíðin mun leiða í ljós í hve ríkum mæli stjórnmálamönnum tekst að halda á loft grænlenskri málstefnu í sama mund og hnattvæðingu Grænlands hrindur fram.

pýđing úr dönsku á íslensku: Sigrún Kristín Magnúsdóttir

\section{Ritaskrá}

Kolte, Svend: »Kalaallit Oqaasii

málstofu um tungumál og fornleifa-

- det Grænlandske sprog巛 (1999): fræði.) Nunatta Katersugaasivia/

Inuit - Kultur og Samfund. Systime.

Grønlandsk Landsmuseum og

Oqaatsivut kulturerpullu - vort sprog Ilisimatusarfik/ Háskólinn í Grænvor kultur. (Skýrsla og erindi úr landi 1986.

\section{Vefslóðir}

Um skiptingu mállýskna og hljóðbreytingar í grænlensku: www.oqaasileriffik.gl/documents/doc/joergen_rischel_dk.doc 


\section{Pantið bókina á slóđinni: www.norden.org/agenter}

Verð DKK 95 (án virðisauka). Verðið er leiðbeinandi og í dönskum krónum og getur pví verið ólíkt meðal söluaðila í mismunandi löndum. Sendingarkostnaður leggst ofan á verðið. Aflsláttur er gefinn af pöntunum fyrir heila bekki.

SÆNSKA Nordens språk med rötter och fötter Nord 2004:8 ISBN 92-893-1043-X NORSKA Nordens språk med røtter og føtter Nord 2004:9 ISBN 92-893-1042-1 DANSKA Nordens sprog med rødder og fødder Nord 2004:10 ISBN 92-893-1041-3 ÍSLENSKA Norđurlandamálin međ rótum og fótum Nord 2004:11 ISBN 92-893-1040-5 FAREYSKa Norðurlandamál við rótum og fótum Nord 2004:12 ISBN 92-893-1039-1 